Portland State University

PDXScholar

6-5-2001

\title{
Toward a Discourse of Mestizaje: The Role of the Patagonian Frontier in the Construction of Argentine National Identity
}

Daniela V. L. Senderowicz

Portland State University

Follow this and additional works at: https://pdxscholar.library.pdx.edu/open_access_etds

Part of the Latin American History Commons

Let us know how access to this document benefits you.

Recommended Citation

Senderowicz, Daniela V. L., "Toward a Discourse of Mestizaje: The Role of the Patagonian Frontier in the Construction of Argentine National Identity" (2001). Dissertations and Theses. Paper 1736.

https://doi.org/10.15760/etd.1735

This Thesis is brought to you for free and open access. It has been accepted for inclusion in Dissertations and Theses by an authorized administrator of PDXScholar. Please contact us if we can make this document more accessible: pdxscholar@pdx.edu. 


\section{THESIS APPROVAL}

The abstract and thesis of Daniela V. L. Senderowicz for the Master of Arts in

History were presented June 5, 2001, and accepted by the thesis committee and the department.

COMMITTEE APPROVALS:

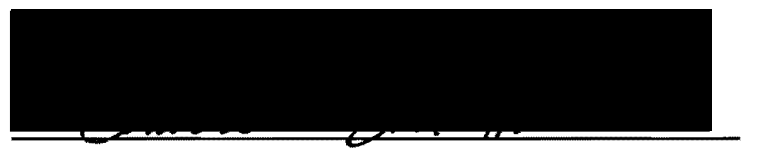

Shawn Smallman, Chair

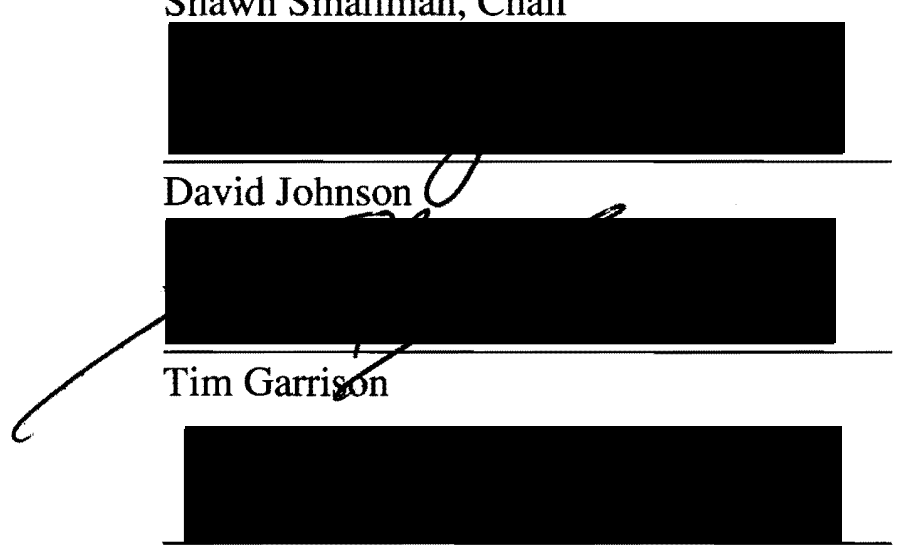

Jorge Lopez, Representative of the Office of Graduate Studies

Lois Becker, Chair

History Department 


\begin{abstract}
An abstract of the thesis of Daniela V. L. Senderowicz for the Master of Arts in History presented on June 5, 2001.
\end{abstract}

Title: Toward a Discourse of Mestizaje: The Role of the Patagonian Frontier in the Construction of Argentine National Identity

This essay will explore the notion of mestizaje in the Republic of Argentina. Specifically, it will use the Argentine Patagonia as a point of departure for this analysis, an area in which conquest resulted in a community of mixed-race and mixedculture individuals. The juxtaposition of the struggle between white settlers and Mapuche-Tehuelche Indians of the region demonstrates a continuity in discrimination in the nation's history. For this very reason, the area represents a general pattern present throughout the country, and, hence, I use it as a prototype to draw conclusions about race relations in the nation as a whole.

I will show that this is a discussion not openly explored in the historiography of the republic. The popular discourses that promoted the creation of a white population is at the core of this issue. Furthermore, the continuation of such discourses into the twenty-first century contribute to the notion of separatism within mainstream, academic, and government circles. Argentina, however, both today and over the past four hundred years, has been diverse and mixed. Because of the complexity of its population, mestizaje is a viable area of study for Argentina. The history of whites and Indians in Patagonia exemplify this analysis. 
TOWARD A DISCOURSE OF MESTIZAJE:

THE ROLE OF THE PATAGONIAN FRONTIER IN THE CONSTRUCTION

OF ARGENTINE NATIONAL IDENTITY

by

DANIELA V. L. SENDEROWICZ

A thesis submitted in partial fulfillment of the requirements for the degree of

\section{MASTER OF ARTS}

in

HISTORY

Portland State University

2001 


\section{TABLE OF CONTENTS}

List of Figures

Page ii

Glossary

Page iii

Introduction:

"Mestizaje in the Southern Cone"

Page 1

Chapter One:

"The Setting and the Peoples of the

Page 15

Southern Extremes"

Chapter Two:

"Sharing Argentina"

Page 38

Chapter Three:

"The Nineteenth Century and the

Page 52

Discourses of National Identity"

Chapter Four:

"The Identity of a Modern Republic"

Page 77

Chapter Five:

"Modern Perspectives and the Indian

Page 107

Space in Society"

Epilogue

Page 120

Bibliography

Page 124 


\section{LIST OF FIGURES}

Figure 1. The System of Castas

Page 7

Figure 2. The Argentine Patagonia and the Patagonia Indians

Page 18

Figure 3. Map depicting Indians of Argentina

Page 22

Figure 4. The Conquest of the Desert, 1833

Page 48

Figure 5. Territory covered by research

Page 83 


\section{GLOSSARY}

Araucanian: Indians originally from the west side of the Andes mountains in Patagonia

Araucanization: the process of mestization of eastern Patagonia by the Araucanians

Araucaria: Araucaria Araucania tree that provides highly nutritious seeds, used by Andean Indians as food staple

Cabecita/Cabecita Negra: modern nomenclature used by Argentines depicting a person of color. Literally meaning "little black head." Name derived from the bird Carduelis Magellanica

Cacique: Indian chief

Castas: system of racial classification established by the Spaniards

Chónik Indians: group in Tierra del Fuego

Conquistador: Spanish conqueror in Hispanic-America

Criollo: American-born person of Spanish ethnicity

Curandera: a healer, often practicing non-Western and Indian healing methods

Encomienda: system of grants to Spaniards for the acquisition of land and tribute by Indians.

Encomendero: Spanish land-grantees

Estanciero: Rancher

Fuegian Indians: group in Tierra del Fuego

Guanaco: a llama-like animal

Hacendado: Individual who owns land, often a rancher or farmer

Hilandera: Weaver

Malón: raid of cattle

Mate: Drink derived from the tree Ilex Paraguariensis, a member of the holly family. native to Paraguay, Brazil, and Argentina

Mapuche: nomenclature for Araucanian people

Mapudungun: Mapuche language

Mestizo: individual of mixed-race and culture

Mestizaje: process of biological and cultural unions between peoples of different backgrounds

Mita: a system of tribute established by the Spaniards

Ñandú: an ostrich-like animal

Ona Indians: group in Tierra del Fuego

Pampa Indians: group in the Septentrional Tehuelche region

Patronato: papal decree giving Spain right to conquer and proselytize the Americas

Pehuenche Indians: Andean group, relative of Tehuelches

Piñon: seed from the araucaria tree

Piñonero: worker who collects piñon seeds for a living

Ranquel Indians: group in the Septentrional Tehuelche region

Reducciones: groupings of Indians under a religious or encomienda setting

Tehuelche Meridional: group in the southern sector of the Argentine Patagonia

Tehuelche Septentrional:group in the northern sector of Argentine Patagonia 
Tejedora: weaver

Yaghan Indians: group in Tierra del Fuego 


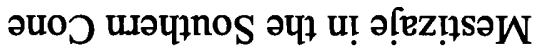
:NOILOกGOYINI 
Since the time of conquest in the Americas, the "Indian question" posed a source of distress in defining social and political spaces. Newly arrived whites saw in the Americas the possibility of extending their world view beyond European borders. The expulsion of Indian beliefs, traditions, and people was key to extending Old World civilization into the New World. American Indians were anomalous to the belief systems of whites; some Europeans even questioned whether the Indians were actually human. The 1550 debate between Bartolomé de las Casas and Juan Jinés de Sepúlveda in Valladolid, Spain is a case in point. The pro-human faction represented by de las Casas argued for moral treatment of the Indians through their conversion to Christianity and instruction in the European ways. De Sepúlveda represented the faction that saw the Indian as inhuman, demanding that the Indian be enslaved to serve the larger purposes of the European way of life. ${ }^{1}$

Different facets of colonialism manifested themselves in the new societies as imperial issues based in Europe determined the overall behaviors of whites toward Indians. A French and English feud for imperial control, for instance, originated in the Old World and was manifested in North America through the creation of favorable alliances with the Indians. ${ }^{2}$ In the Spanish colonies the paternalistic character of the treatment toward Indians was determined by the Patronato which gave the Spanish a divine mandate, directly from the Pope, to conquer the New World with the intent to

\footnotetext{
${ }^{1}$ Hanke, Lewis. Aristotle and the American Indians: A Study in Race Prejudice in the Modern World. Chicago: Henry Regnery Company, 1959.

${ }^{2}$ Imperial questions include the French and English feud for North American land, and the Spanish notion of the Patronato. These larger feuds based in Europe had an impact on how Indians were treated - Europeans' perceptions of Indians did not necessarily decipher their treatment but larger imperial questions determined the most appropriate relational tactics that would serve the imperial interests.
} 
proselytize the indigenes. ${ }^{3}$ Indians were simply peripheral to the larger European aims. In the white world view they would not be integrated into the new societies of the Americas, but would simply stand by and watch as civilization championed over savagery. ${ }^{4}$

Following the centuries of conquest and the independence of American nations, the "Indian question" persisted. Indians did not change into Europeans, nor did they fully disappear into dust. Their presence was still a nuisance to the European world view: the Indians inhabited the lands that the whites desired, and they were seen as brutish and dangerous to civil society. New nations took measures to deal with the "Indian problem" including the physical removal of native groups from desired lands, the signing of treaties that would not be fulfilled, and even the outright extermination of natives. 5

Modernity has not resolved the Indian "problem" either. No advances in technology or education have altered the world view of the transplanted communities of Europeans. Centuries of violence, disproportionate hegemonic relationships, and outright unwillingness to cooperate with the needs of indigenous groups established

\footnotetext{
${ }^{3}$ On the Patronato see Enrique Dussel, A History of the Church in Latin America: Colonialism to Liberation (1494-1979), $3^{\text {rd }}$ ed., trans. by Alan Neely (Grand Rapids, Michigan: William B. Eerdmans Publishing Co., 1981); and Richard E. Greenleaf, ed., The Roman Catholic Church in Colonial Latin America (Tempe: Center for Latin American Studies, Arizona State University, 1977).

${ }^{4}$ For discussions of the transfer of supremacy in the Americas from Indian to European see Dussel; or Robert A. Williams, Jr., The American Indian in Western Legal Thought: The Discourses of Conquest (New York: Oxford University Press, 1990).

${ }^{5}$ For Indian removal of eastern North American Indians into the plains see, among others, Michael D. Green, The Politics of Indian Removal: Creek Government and Society in Crisis (Lincoln: University of Nebraska Press, 1982); James W. Covington, The Seminoles of Florida ( Gainesville: University Press of Florida, 1993). For unfulfilled treaties see David E. Wilkins, American Indian Sovereignty and the U.S. Supreme Court: The Masking of Justice (Austin: University of Texas Press, 1997). For examples of extermination in places like Argentina see Juan Carlos Walther, La Conquista del Desierto: Lucha de Fronteras con el Indio (Buenos Aires: EUDEBA, 1970).
} 
stereotypes that are far from overcome. Exclusion of Indians from the struggles to define national identities is widespread in both North and South America despite the legacy of conquest which built a mélange society. The ethnic and cultural diversity that exists in the continent since the arrival of Europeans has perhaps been the key to defining the character of this part of the world. Interpretations of the Americas, however, predominantly define the history of the continent in relationship to the presence of Europeans. The evidence is in the basic history from which other historical interpretations have been built. Frontier, labor, or social history, for instance, are but part of a dominant historical paradigm that interprets the field from the perspective of nation-building, a concept that is inherently from the Old World. Ethnic studies have perhaps broken the norms of this paradigm, but they essentially focus on separatist notions of cultural identity within the nation-states. ${ }^{6}$ Ethnic discourses in the U.S., for instance, have focused on the specificity of ethnic groups. Rich literature is available on Chicana/Chicano, Asian, or African-American populations. The literature on American Indians is also extensive. The limitation, however, lies in that few discourses speak of integration in which a mixture of cultural models from all types of ethnic identities participate in defining societal prototypes. ${ }^{7}$

\footnotetext{
${ }^{6}$ Although often times it is the intention to study specific groups, particularly the history of Indians in the Americas, it is often difficult to find a study that does not rely on the association of Indians to the larger societies created around them. This is the result of an abundance of biased white sources, and a lack of native, written, historical data

${ }^{7}$ Although these ethnic discourses speak of the integration of one group finding acceptance within the larger models of cultural behavior, or of cultural models adopting the behavior of one group; I have noted a general tendency to avoid the idea of mestizaje in this literature. For more on this topic, see Gary Nash's monumental essay, "The Hidden History of Mestizo America," The Journal of American History (December, 1995, \# 3).
} 
Miscegenation, mixture, diversification, integration, combination, or mélange suggest the notion of mestizaje. This is a risky territory to enter in certain parts of the Americas, including both the United States and southern cone countries. The notion became a discourse of Latin America, particularly Mexico, where writings by individuals like José Vasconcelos promoted the notion of a fully integrated race. ${ }^{8}$ Anthropologist Carol A. Smith suggests that mestizaje is not a topic of consideration in the United States because of the early definitions of what defined ethnic character in this northern territory - people were seen as either black, white, or Indian, despite a person's mixed ethnic background. In the Spanish colonies, on the other hand, there was an early system of definitions that explained the gradations of color and blood mixture among the people. ${ }^{9}$

The gradations of ethnicity that the Spanish defined are evident in posters printed in the 1700's showing the progeny of people with differing ethnic backgrounds. Captions express that "Indians + Spanish $=$ Mestizo," or "Mestizo + Black = Mulato." One ethnic mixture is so complex that the resulting progeny is named "No te entiendo" (I don't understand you). ${ }^{10}$ The posters represented the system of castas created by the Spanish in order to differentiate the class standing of individuals according to ethnicity, with the white and creole establishing social supremacy, and the purely Indian representing the bottom of the class eschalons.

\footnotetext{
${ }^{8}$ Vasconcelos, José, The Cosmic Race, trans. by Didier Jaén (Baltimore: The Johns Hopkins University Press, 1997). Although his definition of a beautiful race suggests integration of all colors in Mexico, his main contention is to eradicate "erroneous" Indian physical and mental factors by placing more white characteristics into the gene pool of Mexico.

${ }^{9}$ Carol A. Smith, "The Symbolics of Blood: Mestizaje in the Americas," Identities, v. 3 (1997), pp. 495521.

${ }^{10}$ Nash, "Hidden History of Mestizo America."
} 
This system of ethnic gradations determined class separations within colonial society. Antagonisms between different classes manifested themselves as racial intolerance.

To associate oneself with a mestizo, for instance, suggested a level of superiority to the Indian, while at the same time a level of inferiority to the white. ${ }^{11}$ Furthermore, defining oneself according to the castas became an ambiguous process as integration became more and more diversified. This volatility persists in modernity, and is particularly noted as new discourses of American ethnic identity emerge. Anthropologist Guillermo Bonfil Batalla, for instance, defies the notion that mestizaje really is the defining characteristic of Mexicans. He suggests that the majority of Mexicans are actually Indian, but have adopted the notion of being mestizo simply as a tool to lift their status within the castas system that still dominates Latin American race relations. ${ }^{12}$ Mestizaje, then, can be seen as a myth, and perhaps as a characterization of societies' aims to "whiten" their progeny to fictitiously "improve" the character of their race within larger class systems.

Anthropologist Norman E. Whitten, Jr., explains that mestizaje can be seen as a notion developed by white elitists to only suggest racial integration within their society. Noting the situation in modern Ecuador, Whiten, Jr. explains that the exclusion of indigenes from upper class circles is the norm in this Andean nation. ${ }^{13}$

Mestizaje, then is viewed as a political tool that propagandizes a myth of cultural and

\footnotetext{
"Smith, "The Symbolics of..."

${ }^{12}$ Bonfil Batalla, Guillermo, Mexico Profundo (Austin: University of Texas Press, 1990).

${ }^{13}$ Whitten, Norman E., Jr. "The Ecuadorian Levantamiento Indígena of 1990 and the Epitomizing Symbol of 1992: Reflections on Nationalism, Ethnic-Bloc Formation, and Racialist Ideologies," in Jonathan D. Hill, ed., History, Power, and Identity: Ethnogenesis in the Americas, 1492-1992 (lowa City: University of Iowa Press, 1996), pp. 193-217.
} 
ethnic integration, when in reality it masks the class separations in society that oppress the indigenous masses.

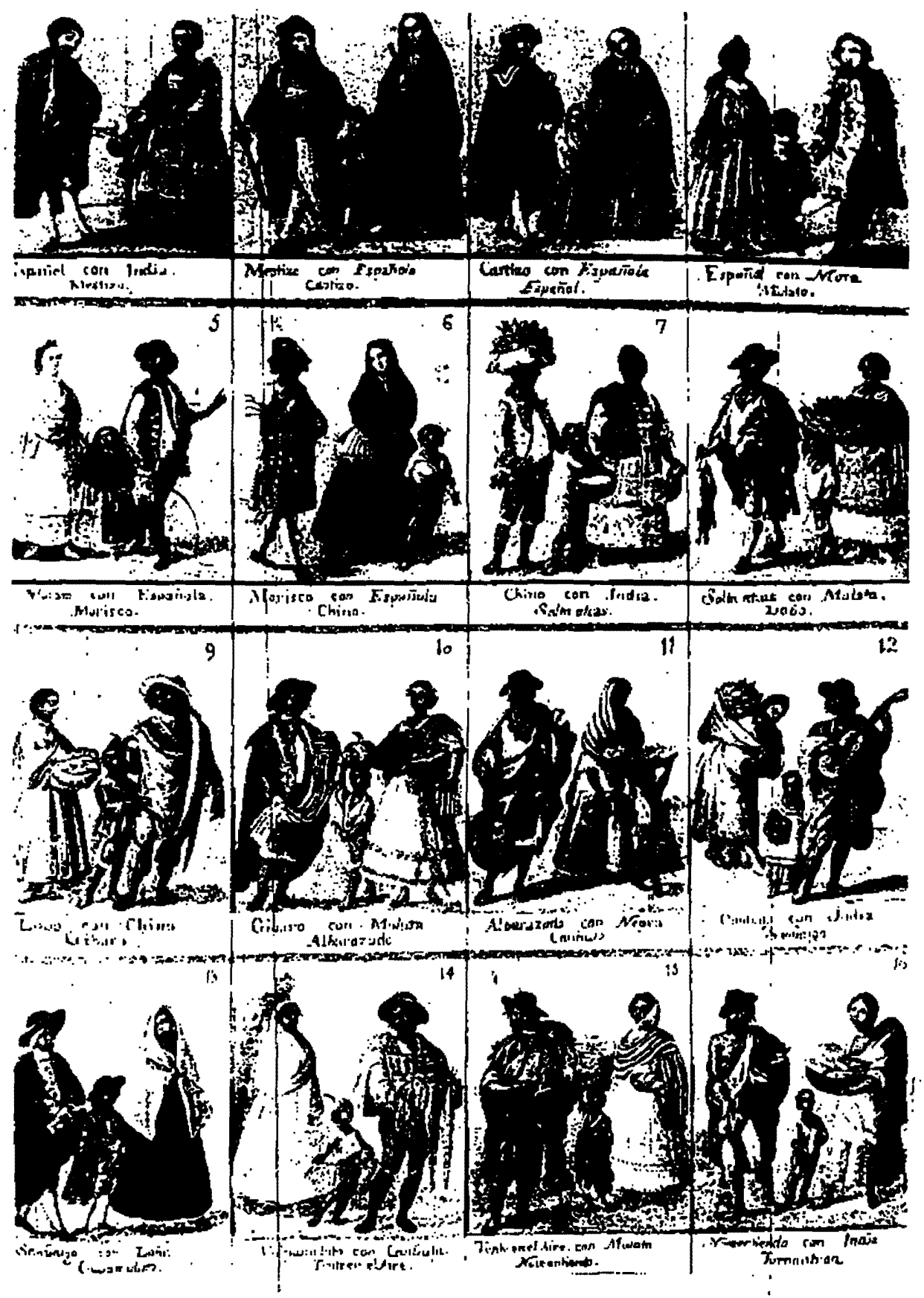

Figure 1. The system of castas, as depicted by an eighteenth century Mexican painter. From Journal of American History, 1995, No. 3. 
The notion of mestizaje is not consistent because of its divergent definitions within different social interpretations. Nevertheless, it is a vibrant representation of identity formation in the Americas. It cannot be fully dismissed as an elitist or inadequate concept as its nature suggests the existence of "mixture," and in a continent where new peoples have emerged as a result of miscegenation, inter-racial rape, and constant immigration from other continents, the mestizaje analysis must be explored to the core. The United States, for instance, has had a movement toward mestizaje over the past several decades, with some historians projecting that the average American will no longer be defined by his Asian, Anglo, Hispanic, or African background, but rather will be a prototype of endless integrated ethnicities. ${ }^{14}$ In the Dominican Republic, furthermore, there is a constant move to marry across ethnic lines. ${ }^{15}$ The presence of mixed African and white descent is a vibrant reality in Brazil. ${ }^{16}$ In locations that have been typically associated with a lack of an indigenous presence, such as the southern cone, we also see the manifestations of racial mixture; specifically in Argentina, the supposedly "refined" European nation of the Americas.

The metaphorical Argentina is a romanticized place, where a city like Paris exists on the banks of the River Plate, the immigrants are of a white European stock, and the transfer of civilized society was easy in light of the lack of Indians that inhabited this "virgin" land. The peoples have looked to the streets of Paris for

\footnotetext{
14 "The New Face of America" Time Magazine Special Issue (Fall, 1993).

${ }^{15}$ Although the intention of many people in the Dominican Republic is to marry into lighter skinned families in order to eradicate dark features in the progeny, suggesting a rejection of diversity, I contend that the intermarriage maintains mestizaje viable for Dominicans.

${ }^{16}$ See Teresa Meade, Civilizing Rio (University Park: The Pennsylvania State University Press, 1997), pp. 29-31
} 
architectural inspiration, to the critical study of Sigmund Freud to pathologically psycho-analyze themselves, and to the rhetoric of the philosophes of the Enlightenment for inspiration on establishing civility in this southern core of European culture. Discourses on Argentine character and identity have been prevalent since the beginnings of its nationhood, with its self-proclamation as an 'immigrant country' and its lively argumentations on the need for civility to overcome barbarism. ${ }^{17}$

Today the discussion of Argentine identity continues almost as a pathological obsession. Who are the Argentines? Why do they feel like they don't belong in the "Third World"? ${ }^{18}$ Why have they been condemned to a life of longing for their ancestral lands? ${ }^{19}$ Argentine newspapers and magazines seek answers to such questions on a regular basis. Even among academic circles, the question of Argentine identity plagues anthropological and historical dissertations. ${ }^{20}$ Racially, the Argentine differentiates himself from the person of indigenous background by proclaiming the non-Argentine characteristics of cabecitas. ${ }^{21}$ They are usually seen as "outsiders" who came to Argentina to take the jobs of the true hard-hardworking (white) people of the country. They are Bolivians or Peruvians with little "culture." They are

\footnotetext{
${ }^{17}$ Starting with the 1853 constitution Argentina defined itself as an immigrant nation. See Galen Joseph, "Civilizing the Nation: Argentine Narratives of Education, Race, and Democracy," Dissertation: University of California at Santa Cruz, 1999, p. 6. Lively characters like the politician Domingo Faustino Sarmiento led the discourse on the need to push for refined white civilization in Argentina (versus a barbaric presence) in his often quoted book Facundo o Civilización y Barbarie. ${ }^{18}$ Joseph, "Civilizing the...," pp. 45, 12-13.

${ }^{19}$ Ramos, Víctor, Racismo y Discriminación en Argentina (Buenos Aires: Editorial Catálogos, 1999), p. 33.

${ }^{20}$ I found seventeen different historical dissertations on national identity in Argentina.

${ }^{21}$ Cabecita (meaning "little head") is a term coined during the Juan Domingo Perón presidency of the 1940's that describes a mestizo in Argentina. See David William Foster, Buenos Aires: Perspectives on the City and Cultural Production (Gainesville: The University Press of Florida, 1998), p. 5.
} 
physically anomalous to what a "true" Argentine really is. ${ }^{22}$ In essence, the Argentine mestizo or Indian is viewed as a non-national, and a member of a separate identity far removed from the acceptable mainstream.

Immigration from peripheral countries received particular attention lately as the popular media and the white sector noted a mestizo presence in the city of Buenos Aires. Complaints of Paraguayans, Bolivians, and Peruvians taking away jobs from the white sector are rampant, and generalizations about this "new stock" of immigrant (as compared to the European immigrants of the late nineteenth and early twentieth centuries) abound. Sociologist Mario Margulis explains that the models of thinking in the racial discourse of today overflow with a lack of reasoning. Stereotypes suggest that non-whites are all " ...bad by nature, are all the same and predictable..... and unappealingly pernicious." ${ }^{, 23}$ Citizens have vocalized their distaste of a diverse Buenos Aires by suggesting that all dark people should be put in one shack to "then set it on fire. ${ }^{24}$ Others, with perhaps a little more gentleness, insist on the notion that the non-white sector belongs to a non-Argentine "otherness." For instance, a poster posted all over the city of Buenos Aires by the national construction union in 1998 said, "Do not give them this day our daily bread with the importation of clandestine labor. ${ }^{25}$ Resentment toward non-whites taking over jobs in recent years juxtaposes the reality that according to the 1991 census, only five percent of the total population

\footnotetext{
${ }^{22}$ Margulis, Mario. "La Discriminación en la Discursividad Social" (Discrimination in Social Discourse), in Mario Margulis, Marcelo Urresti, et. al., eds., La Segregación Negada: Cultura y Discriminación Social (Buenos Aires: Editorial Biblos, 1998), pp. 17-36.

${ }^{23}$ Margulis, "La Discriminación...,"p. 27.

${ }^{24}$ Clarin, July 14,1995

${ }^{25}$ Clarin, April 26, 1998. Translation is my own from: "Que no se apoderen del pan nuestro de cada día con la importación de mano de obra clandestina."
} 
was not Argentine, with only $2.5 \%$ of immigrants coming from peripheral countries. ${ }^{26}$ This suggests that the national "otherness" of mestizos is a myth both as a labor weapon or as an indicator of national identity.

Furthermore, contrary to popular myth, Argentina does have a native population. Notions that the Indians all died from disease, were all killed during colonial times, or that there really never were any Indians in Argentina to begin with are disproved by the existence of a rich population of natives. Estimates by the National Service of Indigenous Issues (a governmental agency) in conjunction with the Indigenous Association of the Republic of Argentina (a non-governmental agency) show that in 1977 approximately 344,850 Indians lived in Argentina. ${ }^{27}$ More recent, yet unofficial data, suggest a much greater population of Indians that is over 1.5 million strong, with 300,000 of them living in their original communities, and the rest dispersed in the urban areas of the country, usually living in substandard conditions on the peripheries of cities. ${ }^{28}$ Out of a current estimated population of $37,031,802$, the current estimate accounts for a $2.5 \%$ Indian population. ${ }^{29}$ However, such numbers do not account for mixed-race individuals, or mestizos, which would very likely bring the current population of the descendants of the original inhabitants of the republic to a

\footnotetext{
${ }^{26} 1991$ census statistics. "Archivo de Sintesis de los Datos del Censo '91," published by Instituto Nacional de Estadistica y Censos (INDEC), Ministerio de Economía, Obras, y Servicios Publicos, Secretaría de Programación Económica y Regional.

${ }^{27}$ Servicio Nacional de Asuntos Indígenas del Ministerio de Salud y Acción Social, and Asociación Indígena de la República Argentina, Buenos Aires, 1977. Cited in Hernández, Isabel, Los Indios de Argentina (Madrid, MAFRE, 1992).

28 Ramos, pg. 104.

${ }^{29}$ For census statistics, see Instituto Nacional de Estadistica y Censos, Ministerio de Economía, www.indec.mecon.ar/default.htm.
} 
much greater percentage. The data is not conclusive, and reliance on estimations is currently the best recourse.

Native Argentines have faced the consequences of white foreigners and their progeny struggling to construct their own identities in the southern cone. The system of castas conceptualized in Spain had as much influence here as it did in the larger Spanish colonies of Perú and Mexico. The view of the Indian as sub-human prevailed during colonialism and beyond as calls for their eradication abounded after independence. Through the discourse that called for a civilized Europe in the Americas (epitomized most keenly by politician Domingo Faustino Sarmiento), and the calls for the eradication of the savagery (manifested by President Juan Manuel de Rosas in the 1830's, and later by President Julio Roca in the 1880's) by way of a military push into the frontier, the distaste for the non-white prevailed in the nation's history.

Mestizaje means the mixture of not simply ethnicities, but of culture. ${ }^{30}$ This is the view to which I prescribe throughout this essay, and I insist that the "cosmic" gene pool that integrates every single race into a multiethnically prototypical persona is not as significant to mestizaje as the cultural integration of peoples, and the coexistence of different races within a shared space. This does not imply equality and harmonious co-existence among diverse peoples. Mestizaje is often the representation of class systems in Spanish America in which those with lighter skin enjoy the ownership of goods and resources, and those with darker skin are subject to the rules of whites. Indeed, this is not an equal sharing of space, but a sharing of space nonetheless in 
which a reciprocal exchange of views, behaviors, attitudes, and practices is inevitable. The interchange which I imply in the term "cultural mestizaje" takes place in smallscale transactions among peoples within the street, the market, the arts, and conversations. The result of such petty exchanges is richly diverse communities, and at the same time complex and segregated societies.

With this view I contend that in essence, the clash of cultures in Argentina between the Indian and the white has inevitably made Argentina a vibrant mestizo society. Through the exploration of the events of the seventeenth- through twentiethcenturies we will see how mestizaje shows itself to be a viable indicator of Argentine identity. Furthermore, I selected the southern area of Argentina as the basis of my study to demonstrate how mestizaje developed throughout the whole country as a process of cultural clashes and readjustments. Although the majority of the Indian population resided, and still resides, in the north of the republic, the rhetoric of Indianwhite relations that emerged from discourses about the Patagonian territory are key to understanding the modern ideologies that place the Indian into the Argentine imagination. Northern Indians, such as the Tobas or Kollas, were subject to earlier colonization under the Spanish crown, and through Jesuit missions that placed them into reducciones (spaces in which Indians lived, worked, and worshiped, under the supervision of religious personnel). Although important to the notion of mestizaje in Argentina, they were already "civilized" by the time the national discourses appeared in the nineteenth century. The relationship of the discourses to the activities of the Indians of Patagonia, I contend, are significant to the views of national character and

${ }^{30}$ Smith, "The Symbolics...," p. 496. 
race that exclude all indigenous and mestizo individuals from modern society. ${ }^{31}$ I will demonstrate that the official and rhetorical attempts to replace the indigenous population of Patagonia have simply contributed to a mythical construction of identity and nationhood. Furthermore, I will show that the tension of the historical construction of Argentina's racial character endures through the pervasiveness of archaic myths in everyday modern discourse. In the end I hope to propose the notion of mestizaje in Argentina as an inevitable consequence of being a part of the Americas, and more importantly as a viable area of study.

\footnotetext{
${ }^{31}$ On early colonial settlements, reducciones, and Indian-white relations see Gabriela Alejandra Peña, La Evangelización de Indios, Negros, y Gente de Castas en Córdoba del Tucumán Durante la Dominación Española (1573-1810) (Córdoba, Facultad de Filosofia y Humanidades, Universidad Nacional de Córdoba, 1997); and Enrique Dussel, A History of the Church in Latin America.
} 


\section{CHAPTER ONE:}

The Setting and the Peoples of the

Southern Extremes 
Spain's arrival to the Americas created a cultural collision between two utterly different worlds. Indian domination of the land deteriorated as the force of Christianity and hunger for riches gave the Spanish the momentum to conquer the land without remorse. The Pope's divine mandate to conquer, the myths of enchanted lands covered in gold, the seduction of European largesse through the appropriation of colonies, and the sheer curiosity to understand the purpose of the Indians' existence dominated Spanish perspectives. Without avail to the human presence in the Americas, Spaniards became conquerors who considered theirs whatever they 'discovered' including land, resources, and people.

Indians responded with awe and with fear to the white presence in their land. In the southeast of what is today the United States, they fled the Spaniards out of fear for their dogs and weapons. ${ }^{32}$ In what today is Mexico, they initially looked to the conqueror Hernan Cortés as the embodiment of a lost god, and at first embraced the Spanish presence. Among the Incas, Pizarro installed a system of labor that enslaved many Indians and disenfranchised the powerful organization of the Incas. Native systems of belief, furthermore, were shaken up throughout the Americas as Spaniards conquered with the support of Christian values that allowed them to challenge the legitimacy of Indian systems of belief and organization.

The clash of cultures was based on two fully different world views. Violence was an inevitable part of this clash as both perspectives pushed against one another to

\footnotetext{
${ }^{32}$ See Charles Hudson, Knights of Spain, Warriors of the Sun: Hernando de Soto and the South's Ancient Chiefdoms (Athens, University of Georgia Press, 1997). Indians learned to fear the Spaniards of Hernando de Soto's exploration who released voracious dogs to devour uncooperative Indians. The
} 
establish a domain. In Patagonia attrition was the powerful weapon that the conquerors used; this came in the form of cultural influences that changed the character of the Indians, and political tensions that led the government of Spain (and later Argentina) to slowly move the Indians out of their lands. In this chapter we will look at the two worlds that met in Patagonia, and explore the facets of attrition that led to the disenfranchisement of the regional Indians in the late 1800s.

\section{INDIAN COUNTRY}

The original Indians of the southern half of Argentina are the Tehuelches. They lived in the Patagonia" region of the country bordered by the Andes highlands to the west, the Pampean plains to the north, the Atlantic Ocean to the east, and Tierra del Fuego to the south. The area is diverse in climate with extreme cold to the south and west, arid conditions in the middle, and a humid environment in parts of the north. The Patagonia is known for its harsh winds that travel from the west by the descent of the Andean currents, and from the east by the ocean winds that meet its flat coastline.

seemingly unbeatable weaponry, which included armory and the usage of horses, led many Indians to flee their villages to avoid encounters with these invaders.

* One of the words for feet in Spanish is pata. A phrase that denotes someone with big feet is patagón. Hence, the name Patagonia. The Chónik Indians of Tierra del Fuego are the Indians that the Spaniards in Ferdinand Magellan's 1520 expedition first encountered in the area. They were described by the chroniclers as tall in stature and having enormous feet. See Antonio Canals Frau, Las Poblaciones de la Argentina: su Origen, Su Pasado, Su Presente (Buenos Aires: Editorial Sudamericana, 1953), p. 166; also see Beatriz Moldes and Antonia Peronja, "Historia de Río Negro, Capitulo I," Publication by the Ministry of Social Issues, Provincial Council of Education, Center for Scientific Investigations of the Government of Río Negro, 1998, p. 35. 


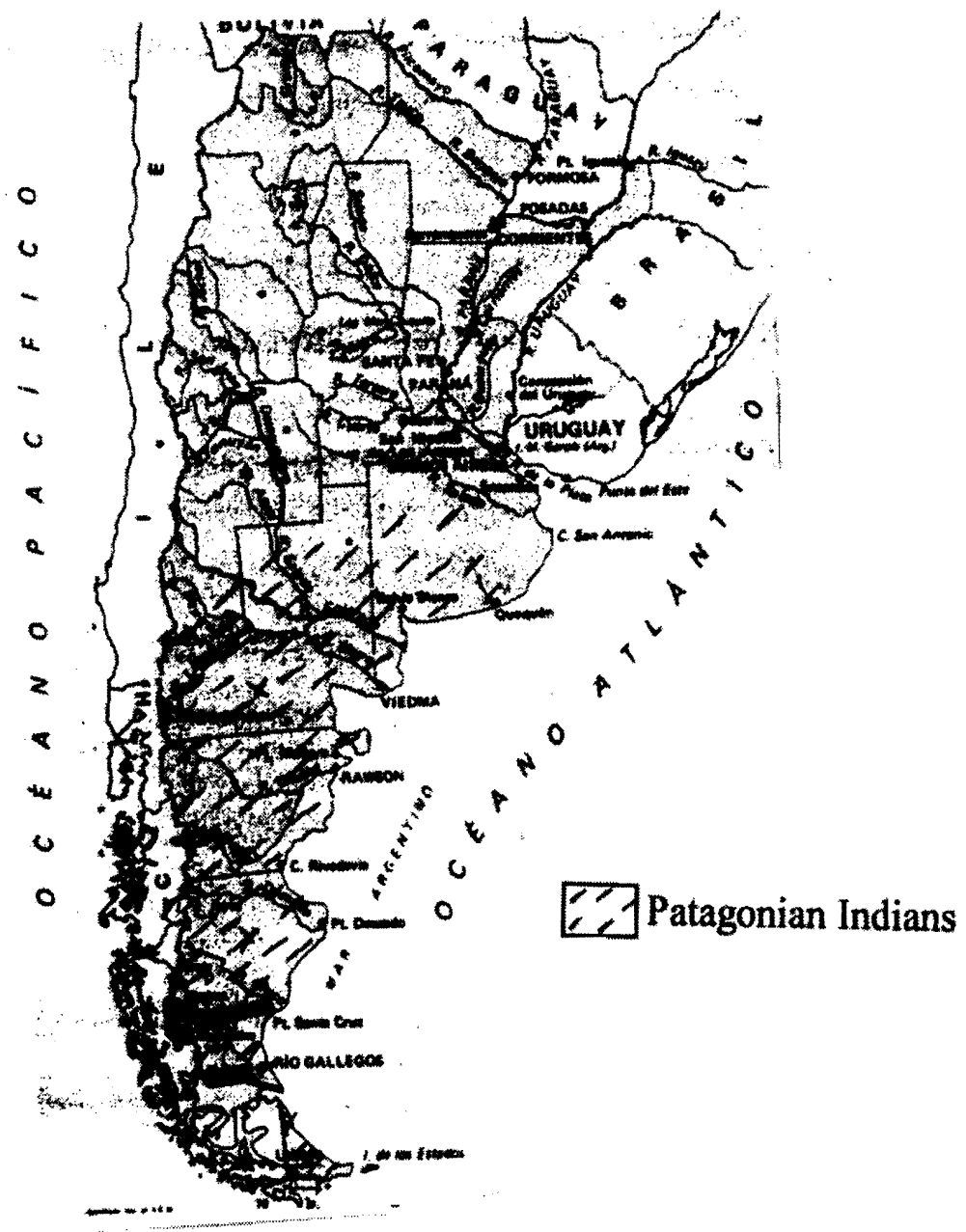

Figure 2. The Argentine Patagonia covers the southern section of the country bordered by the Colorado River in the north. The Patagonian Indians, however, expand north of the river into what today are La Pampa and Buenos Aires provinces. 
Northeast Patagonia is covered with rich humus soils that make it one of the most fertile regions of the world, while other areas are simply barren with grayish brush covering the landscape for hundreds of miles. To the west, a narrow strip of Andean forests is covered with conifers and araucarias ${ }^{* *}$ that can survive the frigid weather. This is a dramatic landscape to which the original inhabitants adapted over thousands of years. Their knowledge of the land gave them sources of food and shelter, and in later times gave them the ability to protect themselves from those who saw Patagonia as a frontier to be tamed and civilized.

It is not known exactly how the Tehuelches arrived to Patagonia. Although the Bering land bridge theory continues to dominate the literature that explains the Indian presence in the Americas, the Tehuelches themselves had their own notions of how they came to be and exist in Patagonia. Through oral tradition, we learn that the Tehuelches believed in one eternal and all-powerful creator named Kóoch, which means "the sky." He was a solitary figure that created an ocean with his tears of loneliness. He created the elements including the sun, moon, and clouds. He made a son with the woman-cloud who named him Elal. He inherited all of Kóoch's powers. ${ }^{33}$ "In times past all of this used to be nothing but water; it was all one ocean," explained a Tehuelche woman by the name of Ana MontenegroYebes in 1963. "Then, when Elal appeared, he created the earth, the world of the Indians. ${ }^{34}$ He then created

\footnotetext{
** Araucarias are millenerian trees that provide a nutritious seed used by residents of the Andean forests in their diets.

${ }^{33}$ Johanees Wilbert, "Introduction," in Jonannes Wilbert and Karin Simoneau, eds., Folk Literature of the Tehuelche Indians (Los Angeles: UCLA Latin American Center Publications, 1984), pp. 8-9.

${ }^{34}$ Alejandra Siffredi and Marcelo Bórmida, "The Emergence of the Earth,", Segment 22, in Folk Literature of ..., p. 36. Siffredi and Bórmida led an expedition in 1963 to the southern Argentine province of Santa Cruz to collect oral narratives from the nearly extinct Tehuelches.
} 
humans by making two clay figurines, explains Yebes, "a man and a woman. He molded them until they became people... until they had blood and a heart. Then the people multiplied." ${ }^{35}$ She explains that the Tehuelche are all descendants of the people that Elal created. ${ }^{36}$ Another narrative explains that Elal married one of the daughters of the sun and moon, and that their descendants are the Ona Tehuelches of Tierra del Fuego. ${ }^{37}$

Archaeological information confirms the presence of those who would become the Tehuelches in Patagonia for the past 12,000 years. The findings at Los Toldos, an archaeological dig in the current province of Santa Cruz, suggests that a hunting and gathering society lived in the area approximately 12,600 years ago. ${ }^{38}$ Other findings have shown that Indians in Patagonia were present in the Atlantic coast in the eleventh century BC, where evidence of their fishing subsistence and of their carved artifacts has been found. ${ }^{39}$

To understand the presence and history of these peoples, I will adopt the nomenclature of anthropologist Carlos Martínez Sarasola who refers to all of the Indians of the region as Tehuelches. The septentrional Tehuelches lived in the northern sectors of Patagonia. The meridional Tehuelches lived in the southern

\footnotetext{
${ }^{35}$ Siffredi and Bórmida, "The Origin of Man," Segment 60, in Folk Literature of..., p. 103.

${ }^{36}$ Siffredi and Bórmida, "The Rising of the Earth and the Origin of Mankind," Segment 62, in Folk Literature of..., p. 105.

${ }^{37}$ W. Hughes, "Origin of the Tehuelche," Segment 57, in Folk Literature of ..., p. 101.

${ }^{38}$ Luz María Font and Gladys Varela, "El Poblamiento del Neuquén desde sus Orígenes a la Llegada de los Españoles," in Estela Cúneo, Luz María Font, Carla Manara, and Gladys A. Varela, eds., Los Hijos de la Tierra: Algunos Capitulos de la Historia Indígena del Neuquén (San Martín de Los Andes: Dirección Municipal de Cultura, Municipalidad de San Martín de Los Andes, 1998), pp. 7-8.

${ }^{39}$ Beatriz Moldes and Antonia Peronja, "Historia de Río Negro, Capitulo II," Publication by the Ministry of Social Issues, Provincial Council of Education, Center for Scientific Investigations of the Government of Río Negro, 1998, p. 27.
} 
sectors of the region. The Onas, who Sarasola also considers Tehuelches, lived in Tierra del Fuego in the southernmost extremes of the Patagonian region. ${ }^{40}$ (See figure 1). Furthermore, within each of these classifications we find specific groups or nomenclatures for Indians such as the Pampa in the septentrional Tehuelche region, the Selknam in the Ona Tehuelche region, or the Patagones or Chóniks in the meridional Tehuelche region. ${ }^{41}$

Each group embodied a different adaptation to the land. The two northern Tehuelche groups were nomads who practiced hunting and gathering. They mainly hunted the guanaco ${ }^{* * *}$ and the ñandü, ${ }^{* * * *}$ but also pursued smaller animals like the fox. They organized themselves by bands of no more than one hundred individuals, with most members being a part of family or extended family units. They would be led by a cacique, or chief, who would organize the hunt or the destination of the bands' moves. Inter-band relationships were friendly when based on commerce, and bitter when a band's hunting grounds were overtaken by other bands, which would usually result in an inter-band war. ${ }^{42}$

The Onas in the south were also nomads. They lived in extended family units within larger bands. They were not led by caciques, except in times of war, but revered shamans and elders as leaders of their group. Although they were surrounded by water they did not develop aquatic sources of transportation, nor did they explore

\footnotetext{
${ }^{40}$ Carlos Martínez Sarasola, Nuestros Paisanos Los Indios: Vida, Historia y Destino de las Comunidades Indígenas en la Argentina (Buenos Aires: Emecé Editores, 1992), p. 64.

${ }^{41}$ ibid.

*** Guanacos are similar to llamas

"*** Ñandús are ostrich-like birds

${ }^{42}$ Sarasola, Nuestros Paisanos..., pp. 67-68.
} 


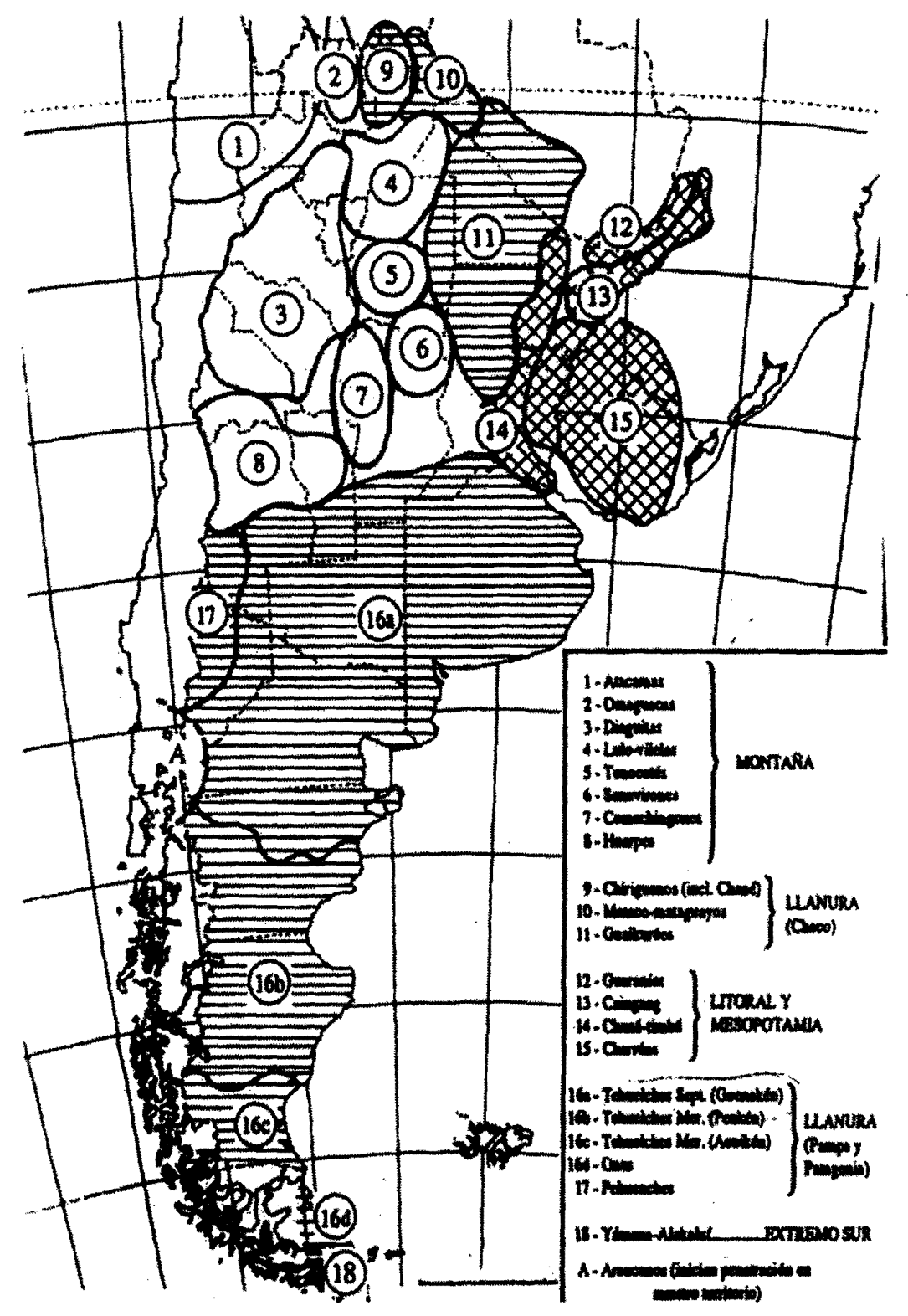

FIGURE 3. Map depicting the Indians of Argentina. The Tehuelches are depicted under sections 16A through 17. From Carlos Martínez Sarasola, Nuestros Paisanos
los Indios. 
the resources of the ocean. They incorporated roots and fruits into their diets, and hunted the guanaco as well as waterfowl such as ducks and swans. ${ }^{43}$

The Pehuenches, considered to be a distant relation of the Tehuelches, inhabited the high Andean region of the septentrional area. ${ }^{44}$ It could be said that they represented the mode of living along the high mountains of the Tehuelche territory. They hunted, but also included the piñon as a major source of food in their diet. This seed from the araucaria tree, incredibly high in minerals and vitamins, is abundant in the high forests. ${ }^{45}$ Perhaps this guaranteed source of food is what gave the Pehuenches a level of independence from other groups in the area, including the Tehuelches to the east and the Mapuche to the west. Anthropologists have described the Pehuenches as emerging separately from other regional groups, and cannot fully account for their presence within the small area they occupy in the high Andes. In this paper, however, I will include them as part of the greater Tehuelche nomenclature for Indians of the Patagonia region.

Knowledge of pre-Hispanic Tehuelche culture is limited, except what has been recovered from archaeological digs and some oral traditions. Most knowledge of the Tehuelches comes from the period following the arrival of Europeans in the Americas, even though the Tehuelches themselves did not come into immediate contact with the colonizers. The impact that contact had on this group is a consequence of European contact with other Indians, particularly the Araucanians who lived west of the Andean highlands in what today is Chile. These westerners dealt with the infiltration of

\footnotetext{
${ }^{43}$ ibid., p. 69.

44 ibid., p. 70.
} 
colonizers who set up the Viceroyalty of Perú in their land. The Araucanians were avid warriors who had previously defeated Incan infiltration into their territory; they used this experience to put up a successful front against the whites for over three centuries, but were ultimately defeated in the nineteenth century. ${ }^{46}$

During the time of European encroachment into Araucanian territory, the Tehuelches had not come into direct contact with whites. For instance, Spanish conquerors set anchor in what would become the city of Buenos Aires in 1535, but their experience there was short-lived and any encounter with the Tehuelches was not noted. In 1580 a second Spanish effort established a colony in the city. ${ }^{47}$ The number of colonizers, however, was minimal and their interest in Patagonia did not materialize until much later. Encroachment of whites into Araucanian territory, however, would have a ripple effect on the lives of the Tehuelches. Araucanians, feeling the pressure of the new colonizers, began to move east of the Andes into Tehuelche territory. This phenomenon began a process in Patagonia called "araucanization," in which the Tehuelches integrated the Araucanians into their culture. ${ }^{48}$

Araucanization took place through the migrations of small groups into Patagonia, and through commercial relationships. ${ }^{49}$ Araucanians sought to acquire horses for their military operations, and found an abundance of them in Pampean

\footnotetext{
${ }^{45}$ Font and Varela, pp. 8-9.

${ }^{46}$ Robert Charles Padden, "Cultural Adaptation and Militant Autonomy Among the Araucanians of Chile," in John Kicza, ed., The Indian in Latin American History: Resistance, Resilience, and Acculturation (Wilmington, Del.: Scholarly Resources, Inc., 1993), p. 75.

${ }^{47}$ Pedro de Mendoza attempted the first colonization, and Juan de Garay fulfilled the second attempt. See Martínez Sarasola, p. 107.

${ }^{48}$ Sarasola, Nuestros Paisanos..., pp. 125-132.

${ }^{49}$ Ibid.
} 
flatlands. ${ }^{50}$ The Pampas Indians of the septentrional Tehuelches traded their horses for the textiles of the Araucanians, and the Pehuenches in the eastern Andes acted as intermediaries in these transactions. In this fashion the Araucanians entered Patagonia, and as anthropologist Salvador Canals Frau argues, their intimate relationships with the Tehuelches led to an inevitable acculturation into the Araucanian culture that led to the extinction of 'lesser advanced' Indian groups in the east of the Andes. 51

Araucanization made sense for the Pehuenches who were traditionally hunters and gatherers. They had some stable agriculture, provided by the araucaria tree, but the opportunities that trade between the Pampas and the Araucanians provided gave them further opportunities to diversify their subsistence. Many acquired pastoral skills by assimilating cattle into their economy. They did not simply consume the cattle, but they also participated in a complex transportation system of cows; their knowledge of Andean terrain made them indispensable in herding the cattle across these high altitudes. They essentially diversified their economy and at the same time acquired the cultural advancements of the Araucanians, particularly their ability to produce textiles. The acculturation of Pehuenches into the Araucanian traditions was completed through the adoption of the Araucanian language. ${ }^{52}$ Araucanization, then,

\footnotetext{
${ }^{50}$ The horse had been left behind by the failed exploration of Don Pedro de Mendoza, original founder of Buenos Aires City. See Antonio Canals Frau, Las Poblaciones Indigenas de la Argentina: Su Origen, Su Pasado, Su Presente (Buenos Aires: Editorial Sudamericana, 1953), p. 537. On the use of the horse for defense see Martínez Sarasola, pp. 128-134.

${ }^{51}$ Ibid., Frau considers the Araucanians more advanced for their higher levels of social organization. Others say that they were more advanced because of their refined knowledge of agriculture, and their development of textiles, which the Tehuelches did not have.

${ }_{52}$ Alberto Sarramone, Catriel y Los Indios Pampas de Buenos Aires (Azul, Bs. As.: Editorial Biblos, 1993), pp. 18-21. Also Font and Varela, pp. 13-15.
} 
was an economic process that made sense for the Pehuenches making them viable in a larger exchange system that emerged throughout the greater Patagonian and western Andean region.

For the Tehuelches, araucanization led to the diversification of subsistence mechanisms. The Araucanian demand for horses created a lucrative market for the Tehuelches who dominated large herds of the animals in the open plains. ${ }^{53}$ Furthermore, they participated in the frontier exchange of cattle by robbing the animals from white ranchers, herding them to the Andes, and submitting them to the trueque ${ }^{* * * * *}$ between Araucanians, Pehuenches, and Tehuelches.

The Araucanians were self-proclaimed "Mapuche," meaning "people of the earth," and the araucanized Indians east of the Andes gradually adopted this title as their own. In the territory that was to become Argentina, the Mapuche lived in communities along the rivers and lakes of the eastern Andes. Prior to araucanization the Tehuelches lived as tribal communities, but afterwards they acquired a hierarchical model. They were structured around a cacique, or group leader, who declared war, authorized the passage of outsiders through local lands, and provided general leadership to his people. Many caciques were powerful and ruled over large numbers of Indians. They also established relations with one another in matters of commerce and defense of the land from colonizers. ${ }^{54}$

\footnotetext{
${ }^{53}$ Walther, pp. 84-95.

***** The trueque was the system of exchange among the Indians of the southern cone region.

${ }^{54}$ Estela M. Cúneo, Luz María Font, and Gladys Varela, "Encuentros y Desencuentros Entre Dos Sociedades. Pehuenches y Conquistadores en el Neuquén del Siglo XVIII," in Estela Cúneo, et. al, eds., Los Hijos de La Tierra..., pp. 41-45.
} 
The Mapuche participation in the trueque, was not limited to exchange among local tribes. They also traded heads of cattle or sheep and processed salt from localized salt deposits for bags of grain, tools, metal, or European clothing from the Chilean merchants to the west or the Indians of the flatlands to the north. ${ }^{55}$ They also created elaborate knitted goods to use in the trueque that were for the most part created by women. In this fashion, women participated in the exchange economy; not only did they knit elaborate textiles to provide clothing, blankets and accessories for their families and themselves, and for using as gifts in the reciprocity processes of the Mapuche, but they did so in order to themselves participate in the trueque. They would often exchange their textiles with merchants or other Indians for corn, wheat, peppers, or other comestibles for their families. ${ }^{56}$

Clearly the land that was at one time the domain of the Tehuelches became culturally diversified as an indirect consequence of Spanish colonization. This indirect effect is not unique to this part of the Americas. In North America, for instance, the Pawnees of the western plains who chose to isolate themselves from the impact of white settlement were clearly affected by the impact of Europeans upon nearby environments and tribes. ${ }^{57}$ The effects of disease throughout the Americas also

\footnotetext{
${ }^{55}$ Ibid., pp. 53-54.

${ }^{56}$ Ibid., p. 57. Some chroniclers left comments on the richness of men who had many women in their households, commenting on the women's continuous labor as knitters so their husbands could sell in the trueque and acquire wealth.

${ }^{57}$ White infiltration into Pawnee surroundings affected the subsistence patterns of other Indian groups, which in turn affected the patterns of subsistence for the Pawnees. For instance, other groups were forced to find new hunting grounds as white settlements altered their bison populations. Ultimaty, the bison grounds of the Pawnees were infiltrated by other groups whose own bison populations had diminished. This inevitably led the Pawnees to a change in subsistence patterns, and ultimately toward a permanent cultural adaptation that changed their character as a people (synonymous with the Araucanian need to find new lands for their own subsistence, and the impact this had on the Tehuelche
} 
reflected the indirect consequences of Spanish colonization: although many Indians that died never came into contact with colonizers, they indirectly suffered from the effects of larger systems of change that were implemented after contact.

The meeting of Tehuelche and Araucanian cultures essentially followed similar patterns that demonstrated the indirect effect of white contact. Araucanization was a meeting of two indigenous groups, and an integration that could be described as the first mestizaje of Patagonia. Although often times used as a way to "whiten" a culture, or as a political discourse which disenfranchises indigenous interests, mestizaje in this time and place was solely a mix of two peoples who adapted to each other. They merged with a striking adaptability and a strong inclination to seek each others' resources and knowledge. This mestization had such an impact on the region that eventually the Indians of Patagonia, particularly to the west, were referred to as the Mapuche. This transformation was essentially an adaptation to the collision of world cultures in other parts of the Americas. A more direct encounter with colonizers would soon happen in Patagonia, and the Araucanian-Tehuelche-mestizo Indians would need to confront the often tragic results that European expansion would bring to their land.

\section{THE SPANISH}

European colonizers saw in the Americas an opportunity to acquire resources, to build status in terms of imperial power, and to spread civilization as defined by 
Christian tenets and practice. The merging of papal authority with secular power during the early Middle Ages showed the genesis of a religious rhetoric which mandated the expansion of Christianity into the lands of infidels. The Spanish received the backing of the Vatican through the Patronato, a system in which the pope gave sole responsibility to Spain to proselytize the New World, and hence extend the Christian empire beyond its European domain. ${ }^{58}$ In sum, the Patronato gave the Spanish claim to all the lands of wild heathens as subjects to the pope's empire.

Spain's rhetoric concerning the need to save poor souls from their paganism eventually transformed into a discourse that supported the economic advancement of Spanish conquistadores, and legitimated war against the Indians who refused to be transformed. The rhetoric gave Spain all rights to the lands of the new continent, and supported the extraction of resources from the Americas while using the Indians as slave laborers. The discussion unfolded in the debate at Valladolid, Spain in 1550, between Bartolomé de las Casas and Juan Ginés de Sepúlveda, on the position of the Indian within the world view of the Europeans. Lewis Hanke, in his work Aristotle and the American Indians, defines the debate as a "first" in the consciousness of western civilization in that the issues of racial prejudice were for the first time placed forth into the public forum. The discovery of the New World was a challenge to the set notions of a world separated simply by "Christians and infidels," and the debates

Navajos (Lincoln, Neb.: University of Nebraska Press, 1983), pp. 168-207.

${ }^{58}$ The Patronato was decreed by the pope in an attempt to seek Spanish military and political protection of the Vatican from French infiltration. See Robert A. Williams, Jr., The American Indian in Western Legal Thought: The Discourses of Conquest (New York: Oxford University Press, 1990), p. 85. 
represented "an attempt to stigmatize a whole race as inferior, as born slaves." 59 Hanke, however, understands that this simply was not racial rhetoric, and that an underlying economic interest dominated the debates making them a "great controversy... to determine the regulations for conquistadores and the proper way to preach the faith. ${ }^{, 60}$ The place of the Indians in this system of empire and economy, then, was the foremost issue shaping the discourse of the time. With the façade of the religious purpose of the Patronato, however, Spain was able to push its agenda of power-acquisition with a righteous and moralistic flair.

Through the Treaty of Tordesillas in 1494 Spain acquired the right to colonize most of South America. ${ }^{61}$ It established a system of viceroyalties as administrative centers for the crown in Mexico and Perú. The crown also authorized the system of encomiendas through which "worthy Spaniards" (encomenderos) acquired title to large pieces of land and forced Indians to pay tribute to the crown through labor. Encomenderos, in return for this privilege, provided military service to the crown and undertook the responsibility of supporting their workers. ${ }^{62}$ King Ferdinand backed the creation of the encomienda system by stating that "because of the excessive liberty the Indians have been permitted, they flee from Christians and do not work. Therefore they are to be compelled to work, so that the kingdom and the Spaniards may be enriched, and the Indians Christianized." ${ }^{, 63}$

\footnotetext{
${ }^{59}$ Lewis Hanke, Aristotle and the American Indians: A Study in Race Prejudice in the Modern World (Chicago: Henry Regnery Company, 1959), pp. ix-x.

${ }^{60}$ Ibid., p. 41.

${ }^{61}$ Mark B. Rosenberg, A. Douglas Kincaid, and Kathleen Logan, eds., Americas: An Anthology (New York: Oxford University Press, 1992), p. 18.

${ }^{62}$ Williams, Jr., The American Indian ..., p. 84.

${ }^{63}$ King Ferdinand's royal order for the encomienda quoted in Williams, Jr., The American ..., pp. 83-84.
} 
Clearly the early discourse that gave Spain the responsibility to proselytize the New World would not exclude the commercial interests of the crown. For the Spaniards, the work of God was intrinsically linked to prosperity at any price. Historian Enrique Dussel explains that because of the eight centuries that Spain was occupied by the Moors (the seventh through fifteenth centuries), Spaniards acquired a spirit of "crusades" in attempting to re-conquer their land. Furthermore, they inherited what Dussel claims is an Arab characteristic, "the tendency to unify indissolubly the aims and purposes of the state and of the Church."64 This dismisses the Spanish commercial interpretation of the Patronato as a cultural fault outside of Spanish character, and it assumes that the link between church and state was unfounded in the western European world view. This is clearly not the case, and perhaps it is more appropriate to interpret the activity of the Spaniards as an element learned through centuries of Christian imperial activity throughout all of Europe aimed at not simply converting infidels, but acquiring land for the Holy empire.

Lewis Hanke suggests that the Spanish had a distaste for manual labor inherited through centuries of struggle to liberate themselves from the stronghold of the Moslems, hence their plans to capitalize on the vastness of the new world would naturally involve the usage of inferior beings to perform the physical labor. ${ }^{65}$ Whatever the tendency of the Spanish in America, we do know that they employed the encomienda to its fullest, saving them from having to do the labor and giving them immense wealth. Such a system was epitomized by the mita in the Peruvian

\footnotetext{
${ }^{64}$ Dussel, A History of the Church ..., pp. 37-38.

${ }^{65}$ Hanke, Aristotle and the..., p.13
} 
viceroyalty as described in an example of forced mine labor by Carmelite friar Antonio Vasquez de Espinosa between 1612 and 1620 :

“According to His Majesty's warrant, the mine owners on this massive range have a right to the mita of 13,300 Indians in the working and exploitation of the mines ... It is the duty of the Corregidor of Potosí to have them rounded up and to see that they come in from all the provinces between Cuzco over the whole of El Collao and as far as the frontiers of Jarija and Tomina ... the mita Indians go up every Monday morning to the locality of Guayna Potosí ..., they climb up the hill, each to his mine, and go in, staying there from that hour until Saturday evening without coming out of the mines . ..,66

Those who did not appear for their mita responsibilities were chained and forced to the work sites, including the caciques who generally had tribal responsibilities that made them unavailable. ${ }^{67}$

In this fashion of enslavement, appropriation of land, and the imposition of Spanish rule-of-law, the Spaniards expanded their empire within the Americas. ${ }^{68}$ It

\footnotetext{
${ }^{66}$ Antonio Vasquez de Espinosa. "Compendium and Description of the West Indies," in Benjamin Keen, ed., Readings in Latin American Civilization: 1492 to the Present (Washington, DC: The Smithsonian Institution, 1942), pp. 93-94.

${ }^{67}$ Ibid.

${ }^{68}$ The spread of disease should be included here, however, I am attempting to show the conscious efforts and intentions of the Spanish, not the biological results of their arrival in the New World.
} 
was a process that hardly viewed the indigenous peoples of the continent as worthy humans. With the development of the castas system the gradations of worthy and unworthy humans was manifested by color of skin, and not necessarily by devotion to Christian tenets. Racist discourse found momentum behind the mask of religious fervor as the definition of unworthiness was linked to "infidel," which suitably described the "Indian" who was the physical manifestation of an "otherness" to proper civilization. The darker skin became a stamp of barbarism within the system of castas. In turn, barbarism represented a lower social order leaving Indians at the bottom of a class system that slowly imposed itself into the Americas. To belong to a higher social class would only be possible for those with a lighter complexion. As Jorge Juan and Antonio de Ulloa explain in their observance of Peruvian culture in the 1700 s, a person of Indian heritage could not be considered a Spaniard unless three generations of consecutive "whitening" occurred among his or her ancestry. For mulattos, four generations were required. ${ }^{69}$ Climbing up the social scale, for those who adopted the new world view that taught the notion of the Indian as inferior, became a question solely of "whitening" one's progeny. By virtue of skin color, non-whites were expelled from the growing dominating social order of the New World and hence

\footnotetext{
${ }^{69}$ See Jorge Juan and Antonio de Ulloa, "Discourse and Political Reflections on the Kingdoms of Perú," ca. 1749 (in Emory University's Culpepper Project: Colonial Latin American primary documents, www.emory.edu/COLLEGE/CULPEPER/BAKEWELL/texts/juanandulloa.html). Considering the taboo of inter-marriage between a white woman and a non-white man, such a possibility was scarce for indigenous or mestizo men, unless they had daughters that merged with white men. For non-white women, on the other hand, the possibility of marrying a white man was viable in light of the lack of white women that came to the Americas during the conquest. For a discussion on the balance of gender among the Spaniards, see "La Mujer Indigena," in Julio Mafud La Psicologia de la Viveza Criolla.(Buenos Aires: Distal, 1984).
} 
lost control of the resources that would make them independent, or at the very least competitive within a class-based society.

White settlers appropriated the resources of the New World within this system of enslavement and racially-determined class standings. Spanish economic interests expanded while displacing Indians from the new social order. With time, domain over the land and resources that once belonged to the Indians progressively shifted to the newcomers.

In Patagonia, the arrival of the Spanish took place much later than in the rest of the Americas, although the effects of their arrival materialized in indirect ways. The Viceroyalty of La Plata, the seat of the Spanish colonial government that administered Patagonia from Buenos Aires, had historically seen the south as an economic risk. It was perceived to be an area with limited resources, few economic opportunities, and most importantly, populated with unfriendly Indians who, with their ability to survive in the rugged conditions of Patagonia, were able to subdue colonial attempts at conquest. $^{70}$

The Spanish found it difficult to set up sustainable colonial communities in the area. A few attempts were made to explore and chart the territory, but the explorers found the conditions of the land to be difficult. Efforts to explore the two main rivers in the area, the Río Colorado and Río Negro, repeatedly took place during the eighteenth-century by navigators who sailed in from the Atlantic coast; but upstream navigation was dangerous, and the few colonial establishments that were erected on the banks of the waters were complete failures due to the lack of workable farm land 
and to the hostility of Indians. Several attempts were made to establish forts and missions along the rivers, but the viceroyalty was for the most part against spending resources in this area. After considering the repeated failures of the explorers, and with more interest in the precious metals of the northern part of the continent, the viceroyalty decommissioned the conquest of this vast frontier in $1783 .^{71}$

The first European explorers in Patagonia were Spanish colonials who in the sixteenth-century entered from the Pacific coast to find the salt deposits of the eastern slopes of the Andes. ${ }^{72}$ At roughly the same time, the Spanish and Portuguese navigated through the rough waters of the Atlantic coast looking for a passage to the Orient. The vast plains of the area held limited attraction to these early explorers, but the apparition of the legend of La Ciudad de Los Césares (trans.: the city of caesars) in the latter part of the century incited some interest in moving toward the inner stretches of the land. According to the legend, a majestic place existed in the Patagonia, far from the Atlantic, and up in the enormous heights of the Andes Mountains. This city was enchanted, placed at the foot of a giant lake, in a land of tremendous natural wealth. On the eve of Good Friday the roofs of its glorious homes, made of gold and

\footnotetext{
${ }^{70}$ Moldes and Peronja, "Historia de Río Negro...," pp. 27-28.

${ }^{71}$ Adalberto Rodríguez, "Historia de Río Negro, Capitulo IV," Publication by the Ministry of Social Issues, Provincial Council of Education, Center for Scientific Investigations of the Government of Rio Negro, 1998 , pp. 60-61. The viceroyalty later regretted its decision, and petitioned to the King of Spain to establish a guard of the Patagonian coast from repeated attempts by the English at exploring the area. In 1791, the king ordered the immediate establishment of coastal forts to protect the entrance into the Patagonia from foreign explorations. Such acts were later used in the legitimization of Argentine claims to the Patagonia in the Conquest of the Desert.

${ }^{72}$ Luz María Font, and Gladys Varela, "El Poblamiento del Neuquén desde sus Orígenes a la Llegada de los Españoles," in Los Hijos de la Tierra: Algunos Capítulos de la Historia del Neuquén, by Estela Cúneo, Luz María Font, Carla Manara, and Gladys Varela (San Martin de Los Andes, Neuquén:

Dirección Municipal de Cultura, 1998), p. 14.
} 
silver, would shine and be seen from a far distance. ${ }^{73}$ The legend was reinforced as local Indians verified its existence to hopeful explorers. ${ }^{74}$ Optimists, driven by the promise of a land in line with the mythical El Dorado, continued to send explorers to the area to find the city even as late as the end of the eighteenth century. ${ }^{75}$

Interest in the area was incited not only by the legend, but also by the quest to maintain Spanish sovereignty over the land following repeated attempts by English navigators to explore and conquer Patagonia. Attempts by the viceroyalty to establish a colonial presence repeatedly took place in the late eighteenth century. Voyages of exploration charted rugged territory, missionaries established reducciones, and the viceroyal metropole sent military-political officials to set up fortifications and lead communities of colonials throughout the area. Most of these attempts were barely fruitful, but they did establish a Spanish occupation which entitled Spain to sovereignty over Patagonia. ${ }^{76}$

The Indians benefited from the colonizers' incompetent survival skills which allowed the natives to maintain almost complete autonomy over their lands and resources for a much longer time than other Indians of the Americas. Not until the late nineteenth-century did the Indians of Patagonia surrender to the frontiersmen who

\footnotetext{
${ }^{73}$ Exhibition of the War of the Desert, Museum of the Patagonia "Francisco P. Moreno," Administration of National Parks, Office of Nahuel Huapi National Park, Río Negro, Argentina, 1999 2000 Exhibition.

${ }^{74}$ It is said that the legend emerged from the loss of an expeditionary navigational fleet in 1549 led by Sebastián Argüello. Three of the four boats were washed ashore, and the whereabouts of the survivors were never known. Theories of their ultimate fates led to the legend which suggested that they had set up an enchanted land in Los Césares. See Adalberto Rodriguez, "Historia de Río Negro..."

${ }^{75}$ The Viceroy of Perú, with hopes of finding gold and other precious metals, commissioned the Franciscan Fray Francisco Menéndez to explore the shores of Lake Nahuel Huapi with the object of finding Los Césares. See Font and Varela, pp. 5-19

${ }^{76}$ Adalberto Rodríguez, pp. 52-61.
} 
sought to civilize the 'barbarism' of the natives and acquire their lands for private use and exploration.

Throughout the eighteenth and nineteenth centuries Patagonia was a frontier, much like the West in the history of the United States. The ruggedness and vastness of the land held a mythical appeal that suggested the notion of "possibility" for the Argentine government. This was based on the view of the area as a clean canvas in which an ideal society could be painted. Patagonia represented a last frontier in which the conquest experiment could be carried out with a distinctly Argentine flair (a characteristic that the young country still had not defined but hoped to discover as it entered the 'virgin' territory). The "Conquest of the Desert," as it is called in the history books, was a military campaign in the nineteenth century that sought to both exterminate and displace the Indians of the Patagonia. The conquest would civilize the wild frontier, and make the final push for an eradication of barbarism in the continent. After two attempts, one in the 1820's and another in the 1870's, the goals were met and the territory was supposedly vacant: the Tehuelches that at one point had dominated the land were virtually extinct, the Mapuche were forced back to the high Andes, and the Argentine vision for building an appropriate national character would be implemented. The clash of two worlds materialized and the genesis of a fragile search for the identity of a new nation unfolded. 


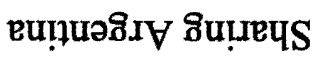

:OML УヨLd 
Indians and whites shared the Patagonia until government plans for civilization marginalized natives and gave property rights to those of European stock. Before 1876, when the second Conquest of the Desert formalized the transfer of lands, the south had a distinct regionalized economy and social system that adapted to the cohabitation of the two racial groups. The whites appropriated large areas of land for raising cattle, and the Indians appropriated the cattle into a "black market" trade with western South American buyers. This was a time of tumult and disarray, and as we shall later see the white interpretation of events during these times promoted the loathing of Indians and a plan to seek an Argentine identity far different than the indigenous one.

\section{THE CATTLE ECONOMY}

Before colonization the Patagonia was the domain of animals like guanacos, foxes, or ñandús. Horses first touched this land in the early 1500's when Pedro de Mendoza attempted to set up a colony in what today is the city of Buenos Aires. His attempt to colonize the land failed, but due to the abundant grasses of the Pampas the horses freely grazed and abundantly multiplied. ${ }^{77}$ The Tehuelches adopted these wild horses and integrated them into their warfare and hunting expeditions. ${ }^{78}$ According to anthropologist Carlos Martínez Sarasola, the Indians became excellent equestrians, and handled the horse with a natural flair.

\footnotetext{
${ }^{77}$ Carlos Martínez Sarasola, Nuestros Paisanos Los Indios..., pp. 107 and 125.

${ }^{78}$ Ibid., pp. 125-126.
} 
"The indigenous horse is unique. No other can be compared to it. It is trained in such a way that a combination of docility, fortitude and velocity make it unbeatable. The Indian is on top of him all the time. Not only when he travels, but often times when he sleeps, drinks or looks at the horizon... Entire days galloping in these geographies end up giving the animal an exceptional state; later placed in the flat terrain he is unreachable to his relatives belonging to the military or the gauchos.,"79

By the time new conquistadores arrived in their lands, the Tehuelche Indians were well prepared to resist the invasive methods of conquest that Spaniards had used in other parts of the Americas quite successfully. For instance, Indians in the southeast of the United States did not fare well militarily when they faced the Hernando de Soto expedition; the horse, among other things, gave the Spaniards ease and speed in military operations which made Indian resistance by foot unsuccessful. ${ }^{80}$

Tehuelches were masters of their land; they understood the unforgiving terrain, and dominated resources effectively to defy those who wanted to appropriate their space. Indian resistance to the Spaniards was intense throughout Patagonia, even as far north as the vicinity of Buenos Aires city. In the sixteenth and seventeenth centuries, the southern Indians suffered a dramatic conquest that was led primarily by

${ }^{79}$ Ibid., pp. 236-237. Translated by author of this thesis.

${ }^{80}$ For more on the activities of the Hernando de Soto expedition into the southeast, and the usage of the horse in subjugating Indians of the area see Charles Hudson's Knights of Spain, Warriors of the Sun: Hernando de Soto and the South's Ancient Chiefdoms (Athens, University of Georgia Press, 1997). 
encomenderos who clearly had financial interests in the land. The first encomenderos appeared during the Juan de Garay expedition in 1580; after arriving in the River Plate area and establishing the city of Buenos Aires, de Garay distributed the lands among his crew and gave them title to the abundant wild horses that roamed the countryside. ${ }^{81}$ Encomenderos quickly found an interest in appropriating more lands and gradually pushed Indians into the interior through methods that perhaps instigated the fierce Indian resistance to white infiltration. Encomenderos turned Indian lands into ranches, and tended to acquire these estates by letting their cows loose on the crops and hunting grounds of the natives. Harvests were destroyed by grazing cattle, and hunting grounds taken over by all types of non-native bovines. ${ }^{82}$ Indians were pushed inland as subsistence crops and hunting grounds disappeared; they had ample reason to detest the infiltration of Spaniards who clearly arrived south not to learn and share the practices of the natives, but to take over their domain.

Although today the cattle industry dominates the Pampas and southern lands of Argentina, cattle are not native to the area. Cattle were imported into Argentine territory in 1580 from Paraguay; cows, goats, sheep and other domesticated bovines were introduced by settlers who wished to replicate their European farming lifestyle in these lands. ${ }^{83}$ Farming was a sign of civility and it juxtaposed the Indian hunting habits that whites considered barbaric. Religious communities during the period

\footnotetext{
${ }^{81}$ Sarramone, Catriel $y . . .$, p. 26.

${ }^{82}$ Sarasola, Nuestros Paisanos..., p. 102.

${ }^{83}$ Walther, La Conquista..., p. 36. Later, starting in the seventeenth century, cattle were a lucrative resource for colonists who participated in the market by selling their herds or cow leather through the port of Buenos Aires. Cattle were so profitable to this area, that the colonial decrees that limited trading only through the port of Buenos Aires were constantly violated by whites who made tremendous gains through an illicit trade west of the port. Ibid., pp. 91-92.
} 
insisted that Indians live in reducciones ${ }^{*}$ and missions within a farming framework of subsistence. Later, the practice became a cause for frustration as land-hungry whites viewed the hunting grounds of Indians as obstructions to the spread of civil settlements. ${ }^{84}$ Among the Tehuelches hunting of wild game declined as raiding of herds increased due to the availability of cattle. The differing manner in which whites and Indians managed the cattle did not erase the dichotomy of civilization and barbarism that farming versus hunting had established. In essence, cattle management replaced hunting as the metaphor for the greater cultural differences that separated whites and Indians.

Natives did not simply retreat into the periphery of their old lands to practice the same methods of subsistence that they had before, but found in the new cultural environment that surrounded them a way to subsist and integrate themselves into a larger economic system. The presence of cattle provided opportunities for them to participate in the trade with other Indian groups and Chileans on the western side of the Andes. They acquired cattle through the appropriation of freely roaming animals

\footnotetext{
${ }^{*}$ Reducciones were spaces in which whites attempted to place Indians so they could live in civility by practicing agriculture and Christianity. Most often times they were run by Spanish missionaries For an example in the southern cone see James Saeger, "Eighteenth Century Guaycuruan Missions in Paraguay" in Susan E. Ramirez, et. al., Indian-Religious Relations in Colonial Spanish America (Syracuse: Maxwell School of Citizenship and Public Affairs, 1989). In the Patagonia, attempts to erect reducciones included the Jesuit mission at the Inmaculada Concepción de Nuestra Señora de Los Pampas, which at one point reduced up to 300 Indians to a lifestyle of farming. This reducción disintegrated by 1753 , due to small pox outbreaks and the dissent of Indians. On other reducciones see Sarramone, pp. 33-35.

${ }^{84}$ On hunting and its views by whites see James Axtell, The Invasion Within: The Contest of Cultures in Colonial North America (New York: Oxford University Press, 1985); Michael Green, The Politics of Indian Removal: Creek Government and Society in Crisis (Lincoln, Neb., The University of Nebraska Press, 1982); among others.
} 
to which white land owners claimed title. ${ }^{85}$ This was a source of constant conflict as settlers complained of the Indian tendency to "rob" white property, perhaps not understanding that the Indian point of view saw freely roaming animals as game. A landowner in the Pampas, explained that to the Pampas Indian,

“... every animal is good game, therefore he ignored judicial adages, and did not know that according to one of them, supposedly everyone should know the law. How was he to understand what the Europeans understand to be property? ... to him, to whom every animal of the plains is game and not cattle, to him who does not know anything but hunting and the right of the first inhabitant, they want to make him understand that those animals ... belong to someone and that appropriating them is committing robbery, and that robbery is a crime. ${ }^{.86}$

The native behavior clearly conflicted with the rules of civility, which called for a transformation of belief systems that were perceived as barbaric. The European perspective of hunting separated the Indians as "outsiders" to civilization.

\footnotetext{
${ }^{85}$ Although the Indians appropriated herds from ranches, they also appropriated cimarrones, or unbranded cattle. White ranchers considered these free-roamers their own property and denounced the Indians as thieves. It is important to remember, however, that the cattle often roamed on Indian lands; hacendados encroached these areas that provided rich grazing spaces, by releasing their cattle further away from the colonial metropole. In essence, this was not always a matter of Indian thievery, but of white hunger for more land. See Walther, pp. 90-91.

${ }^{86}$ See Emilio Daireaux, Vida y Costumbres en el Plata, Tomo I: La Sociedad Argentina (Paris and Buenos Aires, 1888), p.74. Translated by author of this thesis.
} 
The misunderstanding of the native point of view within the powerful landowning circles led to measures to "correct" the activities of the Indian; in other words, to correct the barbaric behaviors of the Tehuelches. The viceroyalty, and later the independent provinces, took steps to protect the lands of encomenderos (who later would become known as hacendados), including setting up military forts that established a frontier line separating Indian from white territory, and signing peace treaties with specific caciques who did not represent all Indians and did not, according to white military sources, adhere to the terms of the treaties. ${ }^{87}$ White landowners did not adhere to the treaties either; their hunger for land prompted them to move beyond established frontier lines without regard to the efforts made to pacify relations with Indians. ${ }^{88}$ The signing of these pacts, however, was an important instrument for the colonial government for it believed that only through cordial relationships with the natives could they acquire their assistance in efforts to resist imperial infiltrations. In 1806 and 1807, for instance, natives participated in the expulsion of English colonists who had invaded the city of Buenos Aires. ${ }^{89}$

Despite attempts to pacify relations and "civilize" Indian behavior, the Indian acquisition of cattle ultimately became a bloody ordeal. Indians led raids on horseback to appropriate cattle from white lands, and often killed or were killed in the process. The perpetual raids became known as malones. A malón would often consist of several Indians attacking an hacienda by surprise and herding the cattle into their

\footnotetext{
${ }^{87}$ Sarasola, Nuestros Paisanos..., pp. 140-141.

${ }^{88}$ Walther, La Conquista..., p. 95

${ }^{89}$ Ibid., p. 122.
} 
own territory. ${ }^{90}$ In 1740 , for instance, a malón led by the Cacique Cangapol into the township of Magdalena, on the Coast of the River Plate (just north of the Bay of Sanborombon), resulted in the killing of 200 colonists, the abduction of many others, and the appropriation of 20,000 heads of cattle. ${ }^{91}$

The criollos ${ }^{* *}$ that owned the lands feared the malones and sought government protection from these raids. In 1824, for instance, a group of fifteen hacendados from the province of Buenos Aires signed a letter directed to the military in which they asked for protection of their cattle, claiming of the "indolence of the government" in not "defending its property." $"$ The behavior of Indians within the cattle economy, among other factors, gave momentum to the discussions that sought to establish a white domain in the Pampas. As we will later see, writers and politicians derived a rhetoric of progress and development by juxtaposing white, civilized behavior against barbaric Indian behavior which included the malones.

To the Tehuelches, cattle were a lucrative resource. Some Indians learned to skin cows and participated in a leather exchange throughout the plains. ${ }^{93}$ They traded their leather with Dutch, English, or Portuguese ships that awaited to trade European

\footnotetext{
${ }^{90}$ Ibid., pp. 89-91.

${ }^{91}$ Ibid., p. 93.

** Criollos are the American-born descendants of the original Spanish settlers.

${ }^{92}$ Letter to Señor Comandante Politico y Militar, signed by fifteen hacendados including Matheo Lupin, Agustin Marguiando, Antonio Gonzalez, José Rial, Lucas Poza, Benito Crespo, Pedro Crespo, Alan Alvarez, etc. 1824. General National Archive, Buenos Aires, Argentina, Folder X13.4.4 (1824) "Plan de Colonización."

${ }_{93}$ According to an hacendado in Buenos Aires province, the leather trade was conducted with stolen cows from throughout the plains area. Complaining of the extent of the stolen property he states that "all to constant and notorious is the pillage of cattle by the barbarians." Letter from Dr. Jorge Gernadas to the governor of Buenos Aires, August 29, 1824. General National Archive, Buenos Aires, Argentina, Folder X13.4.4 (1824) "Plan de Colonización."
} 
goods on the shores of the Atlantic far south of Buenos Aires. ${ }^{94}$ The cattle were also herded across the Pampas, and over the Andean high range to Chile where the animals were scarce. The trade was an intricate exchange in which plains Indians often traded the cattle with Pehuenches, who would then trade the animals with Chileans. In return, Indians would acquire all sorts of European goods including needles, knives, buttons, grain, textiles, and ribbons. Other times, Patagonian Indians profited from the cattle exchange by charging territorial passage fees to herders on their way west. ${ }^{95}$

Colonial authorities were astonished to find that many of the malones were instigated by criollos who were running from the law or who simply took advantage of the absence of laws in the countryside. They would often take refuge among Indian settlements and would instigate the malones by paying money or alcohol in exchange for the cattle. ${ }^{96}$ The merging of peoples was essentially a result of the market. According to historian Daniel Usner, cultural convergence often occurs because of small-scale exchange between peoples. ${ }^{97}$ Petty interchanges between Indians and criollos (including not just the incitement of malones, but also the exchange of textiles between Pehuenches and white merchants, and the trade of leather with sea-faring Europeans) posed a significant cultural reciprocity that broke down the barriers of castas. The criollos that participated in the exchanges, particularly in the incitement of malones, challenged any white notions that "barbaric" behavior was based solely on

\footnotetext{
${ }_{94}$ Walther, La Conquista..., p. 92.

${ }^{95}$ Luz María Font and Gladys Varela, "El Neuquén Indigena de los Siglos XVIII y XIX," in Gladys Varela, et. al., eds., Los Hijos de la Tierra: Algunos Capitulos de la Historia Indigena del Neuquén (San Martín de los Andes, Argentina, Dirección Municipal de Cultura, Municipalidad de San Martín de los Andes, 1998), pp. 29-30.

${ }^{96}$ Walther, La Conquista ..., p. 91.
} 
race. In essence, joint market efforts between Indians and whites were manifestations of a cultural mestizaje that developed throughout the region. Operating under one common interest, criollos and Tehuelches worked compatibly without the limitations of the socially-defined divide of "barbaric vs. civilized" behavior. Cultural mestizaje, as will be discussed later on, broke down the dichotomy and integrated two peoples unequally, but within the same social structure.

The crisis of the malones was constant, especially in the septentrional Indian region. Indians like the Araucanized Ranquel and Pampa participated in the raids well into the late nineteenth-century right before the final military campaign to eradicate Indian groups. After independence the Buenos Aires provincial government of Juan Manuel de Rosas, a federalist caudillo known for his military thinking and fierce tactics against his opponents, began to push the frontier line further south and west of the city of Buenos Aires. He authorized the establishment of military forts to protect the boundary, and commissioned the exploration of Tehuelche territories so as to continue the push into the frontier. Although Rosas was viewed by many of his white contemporaries as a barbarian, he himself viewed the Indians as the barbarians who would need to be suppressed in the name of civility. He commissioned the first selfproclaimed "Conquest of the Desert," a military invasion that pushed the frontier line far south into the Rio Negro. By 1833, Rosas reported to Buenos Aires that his campaign resulted in the death of thirty-two hundred Indians and the imprisonment of

\footnotetext{
${ }^{97}$ See Daniel Usner, Indians, Settlers, \& Slaves in a Frontier Exchange Economy: The Lower Mississippi Valley Before 1783. Chapell Hill: The University of North Carolina Press, 1992.
} 
$1,200{ }^{98}$ Addressing his troops on the final day of war he praised their work which had "inflicted an almost complete defeat of the Indians of the desert, castigating the crimes and avenging the grievances of the century." square leagues of land for settlement, and allowed for the exploration of the territory and its rivers to gather topographical information to be used in later expeditions. ${ }^{100}$

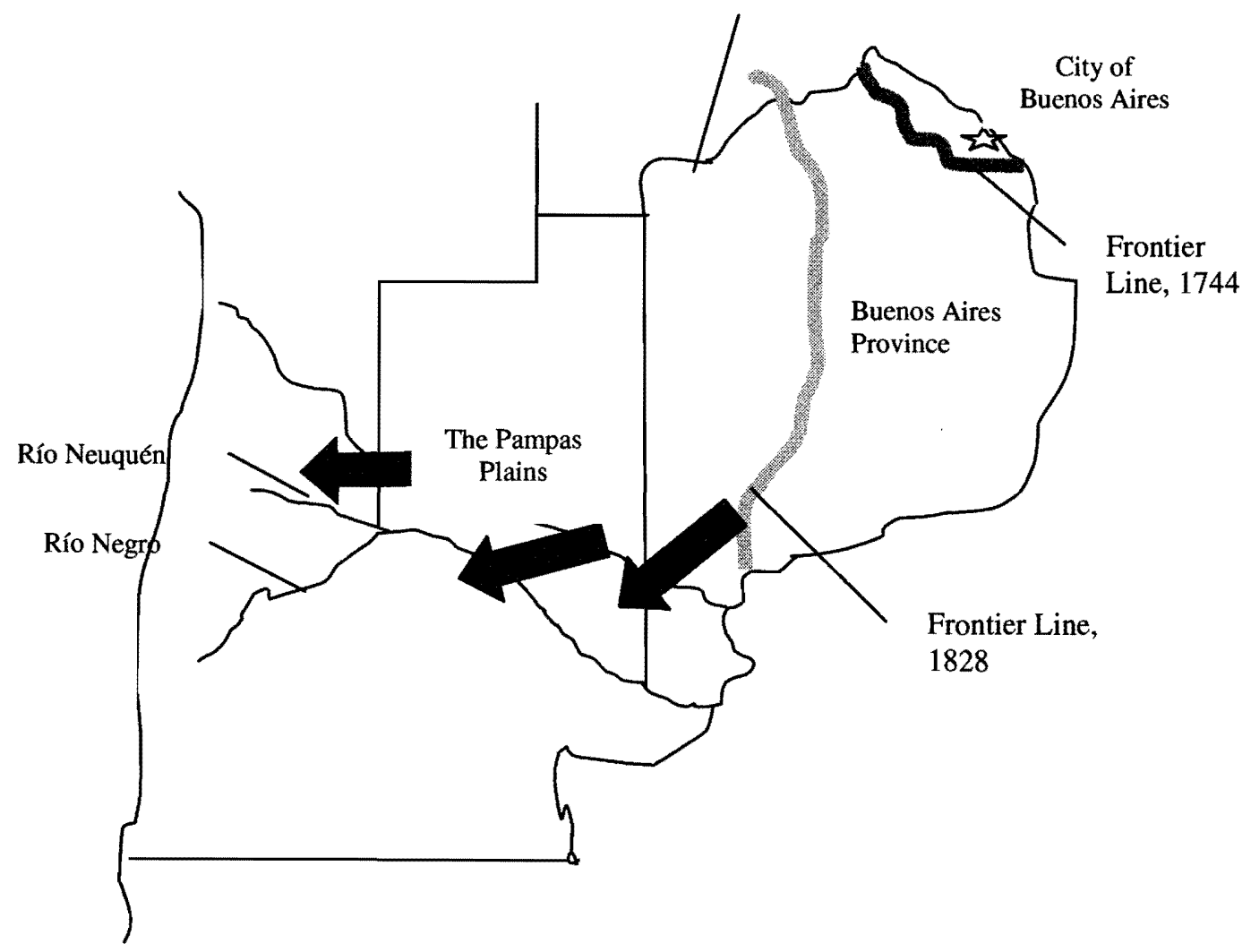

Figure 4. The Conquest of the Desert, 1833. Rosas moved west and south to establish domain over the Río Negro and Río Neuquén.

\footnotetext{
${ }^{98}$ Walther, La Conquista..., p. 235.

${ }^{99}$ Quoted in Walther, p. 234.

${ }^{100}$ Walther, La Conquista..., pp. 235-238.
} 


\section{POPULATION READJUSTMENT}

Indians did not disappear in this campaign, although they were badly bruised and forced to reorganize their cultural space. The Septentrional Tehuelches suffered the most in the Conquest of the Desert, with losses to both land and population. Many communities disintegrated, while others sought protection in the remote sections of Patagonia. Surviving groups re-established their position in the land after the military vacated the area. Some groups were reduced enough in size to set up new communities by merging together. Furthermore, the interest of Chilean Araucanians

in the area persisted, and more of these Indians arrived to set up new communities. ${ }^{101}$ These processes signified a continuation of the mestization of the Tehuelche Indians that had begun with the earlier Araucanian migrations from the west. They certainly were not the same group that had existed prior to the Hispanic invasion; they were shifted within their very own space by whites and other Indians, and they essentially survived the changes by merging with other groups. Like other Indians of the Americas, they were forced to redefine their existence as land for their livelihood became scarce. They found themselves in new lands having to share space and resources and needing to merge or often risk eradication. There is some power in numbers, and indeed the union of these Indian groups allowed for their mestisized survival.

Patagonia as an enigma, much like the North American West was to the United States, may have been the result of how little was known about it. Explorations to map the land, conquer its wild rivers, and make the acquaintance of 
Indians happened in both areas. Gaining control of uncharted territory was exciting, and the hunger of those with rich imaginations fed the frenzy to tame these lands in order to extract their treasures. National character could even be defined by the very success of this quest, in which the enterprising and fruitful spirit of a people could be manifested through the exploitation of rich natural resources. This was the perception of whites who did not integrate the Indian into the notion of "possibility." In fact, the Indian, by virtue of his barbarism, was an impediment to this quest that saw the possibilities of building a utopian civilized society in the virgin territory of the south. The barbarity of the Indian was the pretext used to dismiss him or her from the territory; the Indians did not deserve to be there as they did not know how to arouse the "possibilities" of the area. The perceived inferiority of the Indian, made this individual invisible in Patagonia, feeding the myth that the inhabited area was actually a virgin territory.

After the frontier moved south of Buenos Aires province, and with the myth of the land's vacancy, the Patagonian frontier opened a polemic that sought to build an appropriate national population. The vastness of Argentine territory would need to be populated with a specific type of citizen that would fulfill the aims of the young nation's character. Discourses on this character emerged in the writings of politicians like Domingo Faustino Sarmiento or Juan Bautista Alberdi. They wrote social commentaries that suggested how best to define national identity, and this clearly was centered on a need to transplant innovative European communities to the frontier. The national discussion instigated by the voices of these social observers lasted throughout

${ }^{101}$ Sarasola, Nuestros Paisanos..., pp. 220-221 
the nineteenth century with the advent of the second Conquest of the Desert in 1878 that, like the first conquest, sought to eliminate Indians in order to create a "clean canvas" in which Argentine identity could develop. Immigration incentives appeared to encourage the import of Europeans into the country starting with the enfiteusis law of 1812 , which specifically called for immigrants from the old continent, and continuing well into the early twentieth century with the land grants given to Europeans willing to migrate to Patagonia. ${ }^{102}$

Two parallel worlds operated in this period: a criollo world that sought to establish its governmental and cultural presence and legitimacy, and an Indian world that the white man saw as peripheral and not playing a role in the grand future that Argentina held. The Indian, particularly in the south where the limited white settlements allowed for the Tehuelches to remain living as a free people, was omitted from the blueprint that would someday make Argentina grandiose. With the passing of time the free Patagonians would suffer the defeat caused by a white value system that was still in the process of defining itself. This would come with discourse, propaganda, violence, and the extermination of the Indian from the Argentine imagination.

${ }^{102}$ Andrés L. Lamas, Pamphlet: Tierras Publicas y Colonización (Buenos Aires, Gráfico de Gunche, Wiebeck, y Turtl, 1899), General National Archive, Fondo Roca, Document 1383: Informes de Relaciones y Memorandums, 1833-1899." 


\section{CHAPTER THREE:}

The Nineteenth Century and the Discourses of National Identity 
The Conquest of the Desert in the 1870's moved the Argentine frontier line into Patagonia through a series of military efforts involving attrition, coercion, and extermination. Indian land became the property of the nation to be distributed to specific people in the name of growth, republicanism, and civility. The conquest was a pinnacle of decades of discourse that called for the civilization of the raw and open territory of Patagonia. But this was not a virgin land, as it was occupied by Tehuelches and Mapuches for millennia. Therefore, the military campaign was the physical manifestation of a wish that called for a clean canvas upon which to build an ideal society that expelled the Indian and embraced European value systems.

The wish is expressed in nineteenth-century discourses by Argentine rhetoricians and government officials. They took part in a process that could construct a national identity through the written word. The perfect society that they created on paper would become the traditional "good old days" that later generations would look back upon with nostalgia and remember as the "history" of Argentina. Historian Benedict Anderson describes this phenomenon as an "imagined community" in the process of national identity formation. He credits print capitalism with the ability to spread nationalist ideologies among masses of individuals. The community can be almost fictitious, but because it is described and imprinted on volumes of paper (a tangible, reproducible and permanent phenomenon), and it can be disseminated among peoples who generally do not share much in common, it can become the community to 
which masses give allegiance and historical importance. ${ }^{103}$ Hence, written discourse can establish a paradigm which a country (no matter how "new") can claim as its longterm heritage; the permanency of the written word, therefore, can almost "invent" a historical tradition that establishes nationalism and patriotism among large groups of unacquainted individuals. The discourses of nation building have a tremendous significance to the approaches that governments and societies take to their own issues.

In Argentina this type of rhetoric impacted perspectives of race in relationship to national identity. During the nineteenth-century the Conquest of the Desert was the physical culmination of the ideologies that were implanted into the general consciousness. These ideals sought to secure a "historical destiny" of the white domain. As we will see in subsequent chapters, the discourse continues to dominate attitudes about national identities well into the twenty-first century; the "imagined community" that rhetoricians created is the blueprint from which modern Argentines can oust non-whites from national participation.

\section{THE DISCOURSES OF NATIONAL IDENTITY}

In the early 1800 s localized discussions and experiences dominated the views of whites toward Indians. The fear of malones, and the demands from hacendados to acquire government protection for their land and cattle, established the rhetoric of "Indian Problems." In the letters between landowners and caudillos, such as Rosas, we see constant mention of the need to establish forts and send protection to the

\footnotetext{
${ }^{103}$ Anderson claims that Benedict Anderson, Imagined Communities: Reflections on the Origin and Spread of Nationalism (New York: Verso, 1991)
} 
frontier line. Indeed, the preconceptions of the Indians are noted in these letters as labels of the Indians as "savages" or "heathens" abound. ${ }^{104}$ This is nothing new and indeed demonstrates the slow evolution of early colonial white views about Indians. Although the aim of independence was to break with the archaic culture of the Old World, animosity toward the Indian persisted within the supposedly modern and enlightened new nation. Later discourses, such as the ones by Juan Bautista Alberdi and Domingo Faustino Sarmiento, refined the lexicon of race, but nevertheless maintained the theme of enmity toward natives.

The Enlightenment gave momentum to the region's independence movement and provided the inspiration for national discussions of identity and character. The spirit of the French Revolution was evident in the early discourses of the patriots who led the independence movement in 1810 . The allegory of Rousseau's natural man within his unpolluted environment repeatedly appeared in the rhetoric of Argentine national character. The happenings of early modern Europe intensely influenced the Argentine quest to build a utopia within a virgin land. The natural man could exist in Patagonia, but he could not be created out of indigenes, and therefore would be recruited from the more civilized parts of the old continent. This was a population crisis that called for the replacement of barbaric peoples if any level of enlightened civility would ever envelop the face of the nation.

Juan Bautista Alberdi wrote on the topic of Argentina's perceived population crisis during the mid to late 1800 s. Born in 1810 in the province of Tucumán, he

\footnotetext{
${ }^{104}$ Such nomenclature is found in letters such as Letter to Don Estanislao Lopez, Buenos Ayres [sic], Nov., 5, 1835 and April 4, 1836, Library and Historical Archive of the Province of La Rioja, Papeles de
} 
traveled extensively throughout the southern cone and Europe, and became an attorney in 1840 . He was a social commentator of his times and today is known for writing several important precursors to modern Argentine laws. ${ }^{105}$ In one important essay that he called Bases, he promoted the creation of an idealized national constitution, giving particular attention to the notion of building a suitable populace through appropriate constitutional articles. One of the main themes of Bases is the necessity to create a new stock of Argentine citizen, not associated with the archaic manner of the conquistadores, but nevertheless Caucasian, and preferably of a stock similar to the Anglo-American. Alberdi blamed the Leyes de Indias for maintaining a chokehold on the European settler of South America; the laws, according to the writer, condemned to death any American-Spaniard who came into contact with a foreigner. ${ }^{106}$ He stated that "... disgracefully the execution [of European expansion] found in South America an obstacle in the exclusionary system of the first conquistadores ... The locks and prohibitions of the colonial system impeded the population [of South America] in a fecund and grand scale by the European peoples who left for North America."107. Because of this, he argued, the European population of the southern continent remained sparse - the necessity to attract a variety of white people to such vast areas as Patagonia became a major theme of this essay.

\footnotetext{
Rosas, 1821-1850, Edición Oficial, Autorizada por...Provincia de Santa Fe, 1928.

${ }^{105}$ See the preface in Juan Bautista Alberdi's Bases y Puntos de Partida Para La Organización Politica de La República Argentina (Buenos Aires, Ciudad Argentina Editorial de Ciencia y Cultura, 1998), pp. 7-9.

106 The Leyes de Indias were Spanish colonial laws.

107 "Introduction," in Alberdi, p. 11-13. Translation by author of this thesis. From this point forward all quotes from Bases will be translated by author of this thesis.
} 
Alberdi's disgust for the Spain of colonial times is synonymous with the general feeling of his contemporaries toward the mother country. He was a young man during the height of the Argentine revolution that sought to break from colonial control. The rhetoric of his time praised the republicanism of the French Revolution and sought an Enlightenment of its own for the people of Argentina through a break from the Spanish monarchy. The awakening of this new land naturally would continue to take place within a European world-view, but in the hands of a more diverse population from the Old Continent.

The Indian would hardly fall into this equation, as Alberdi stated in Bases:

"Everything in the civilization of our soil is European; America is a European discovery ... Today, under independence, the indigene does not figure or belong in the world of our political and civil society. Those of us that call ourselves Americans, are nothing more than Europeans born in America. Cranium, blood, color, everything is from the outside. Who knows a gentleman among us that would make it known that he is an Indian? Who would marry their sister or daughter with a man from the Araucania, and not one thousand times with an English shoe maker?"108

Alberdi intended to establish legitimate white control of Argentine land, but with inconcise arguments based on racist passions that were a product of the very Spanish 
culture that he constantly criticized in this work. But he continued with the quest to prove white legitimacy by establishing that,

\begin{abstract}
"America is already conquered, it is Europe and hence unconquerable. The war of conquest suggests rival civilizations, opposing states-the savage and the European, for instance. This antagonism does not exist; the savage is defeated, in America he has no domain or seniority. We, Europeans of race and civilization, are the owners of America." ${ }^{\prime 109}$
\end{abstract}

Alberdi swiftly declared America as a part of the European continent, and hence legitimately open for European expansion: "It is time to recognize this law of our American progress, and return to seek with urgency our incomplete culture from Europe which we combated and beat with arms . . . but which we are far from beating in the fields of thinking and industry." 110 With such words he began to list ideas that would create a more civilized populace in the country.

Indeed, Alberdi believed that Patagonia was open territory for this populationbuilding project, as the land's very essence of "possibility" held its doors open to industrious whites who would exploit natural resources in the name of progress. Furthermore, with the assumption that the land belonged to the European stock, Alberdi almost dismissed the existence of the Indians and erroneously suggested that the area was almost uninhabited:

\footnotetext{
${ }^{108}$ Section XIV in Alberdi, pp. 55-57.

109 Ibid., p. 59.
} 
"What name does a country composed of two hundred thousand leagues of territory and a population of 800,000 inhabitants deserve? A desert ... That country is Argentina, and whatever its constitution it will not be anything other than the constitution of a desert for many years... The constitutions of unpopulated countries cannot have any other serious and rational end ... than giving to the solitary and abandoned territory the population it needs as a fundamental instrument of its development and progress."

The introduction of immigrants, then, was an urgent necessity if Argentina was to take its place among the more civilized nations of the world. The vision involved diversifying the European immigrant community in order to create a population perhaps more perfect than any one found in Europe itself. Alberdi asked if Argentines wanted "... to plant and acclimate in America English liberty, French culture, and the laboriousness of the man of Europe and the United States." ${ }^{112}$ He idealized the United States and believed it to be extremely advanced because of its "incessant European elements." 113 He insisted that their "... habits of order, discipline, and industry"

\footnotetext{
${ }^{110}$ Ibid., p. 59.

${ }^{111}$ Section XXXI in Alberdi, pp. 177-178.

${ }^{112}$ Section XV in Alberdi, p. 65.

${ }^{113}$ Ibid., p. 66.
} 
needed to be planted in Argentina in order to fulfill the legacy of the enlightened national character. ${ }^{114}$

The notion of diversity was alive and well in Alberdi's discourse, although it was quite limited to only inheriting the best European characteristics for the nation. Alberdi advocated providing these immigrants with land concessions in the open desert and attracting them to the area via religious tolerance. ${ }^{115} \mathrm{He}$ argued that the rigid Catholicism of Spanish America kept the Swiss, Swedish, or German from migrating to the continent. ${ }^{116}$ A way to "make the immigrant forget his condition as a foreigner, persuading him that he lives in his own country" would also be another way to attract immigration. ${ }^{117}$ Exactly how this would take place, was not emphasized, but it certainly suggests that European characteristics would be accommodated and embraced as a weapon to eradicate the barbaric features of those that already lived in the frontier, the Indians.

In sum, Alberdi suggested an Americanization of diverse European elements and reassured readers to "not fear ... the confusion of races and languages ... from the chaos will emerge one day a brilliant and unclouded South American nationality." 118 Indeed, Alberdi had his own classification of mestizaje that could only exist under specific assumptions. First, the discourse assumes that the land is deserted, and hence the mestizo that would emerge would be a European mestizo, with

\footnotetext{
114 Ibid., p. 65.

${ }^{115}$ Section XXXII in Alberdi, p. 183.

${ }^{116}$ Ibid., pg. 66. Most certainly, Alberdi considered these nationalities superior within the European continent.

${ }_{117}$ Ibid., pp. 65-66.

${ }^{118}$ Ibid., p. 74.
} 
no indigenous traits. The desertion of the area seemed quite simple to Alberdi: by dismissing the Indians as inferior they were eradicated from the territory - their very inadequacy made them invisible, and the assumption of their submission expelled them from Alberdi's idealized country and from building the white mestizo of his imagination. Surprisingly, Alberdi did not suggest that there was an "Indian problem," but that Indians simply did not belong to the context of Argentina. This is the "wish" that rejected the presence of the Indians, which clearly fed the myth of the virginity of the land which would hold endless "possibility" in the hands of the whites. To people like Alberdi Patagonia was much like an experiment in which the addition of perfect ingredients to vacant territory would result in a utopic society that could not even be matched by the likes of places such as the United States.

Second, the discourse linked economic development and industry to nordic/anglican qualities-almost repudiating the Spanish peninsular immigrant as a separate and condemned race. The white mestizo, under a Darwinist perspective, would inevitably acquire the better characteristics of the nordic Europeans who, by virtue of their superiority, would drive out the unfitting characteristics of southern Europeans. Alberdi suggested that nordic and anglican immigrants would disperse and integrate their qualities into the less refined Spanish criollo perhaps through intermixing and miscegenation. This was a "mestisized" European citizen that would have the best of both worlds: he would acquire all the strong qualities of his parents' ancestry while building a uniquely Argentine identity all his own. 
The assumptions are perhaps representative of a general sentiment that led the Argentine government to act within the parameters of discourses like Alberdi's. As we will later see, laws were passed to accommodate European immigrants and to integrate them into a national consciousness of cultural identity.

The discourse of another important nineteenth-century figure in Argentine history and literature, Domingo Faustino Sarmiento, also influenced the nationalistic rhetoric of the time. A journalist, educator, soldier, and later president of the nation, Sarmiento expounded a number of ideas that would seek to establish a better Argentina. He built schools, inaugurated art institutes, founded the national military academy, and wrote works that remain as a testament to the social antagonisms of his time. Arguably his most famous work is Facundo, a description of what Argentina meant to Sarmiento through the embodiment of a barbarian caudillo named Juan Facundo Quiroga. Written in 1845, Facundo depicted an Argentina that was almost anarchical, embedded in the traditions of outlaws, and too separated from the idealized civilization of Europe or even the city of Buenos Aires. Facundo illustrated the sorry state of affairs in the countryside, where Sarmiento could not help but see the potential that the territory held, but where barbarism stood as an obstacle to the innovations of development and progress. Buenos Aires city is the only place where civilization had accumulated, he stated, and "the Pampa is a very bad conductor to take and distribute it into the provinces."119

\footnotetext{
${ }^{119}$ Domingo Faustino Sarmiento, Facundo or Civilización I Barbarie: Vida de Juan Facundo Quiroga I Aspecto Físico, Costumbres, I Abitos de la Republica Arjentina [sic] (Santiago, Chile: Imprenta del Progreso, 1845), 1999 edition by Emecé Editores, S.A., Buenos Aires, p. 43. Translation by author of this thesis. From this point forward all quotes from Facundo will be translated by author of this thesis.
} 
According to Sarmiento, the problem with the countryside had to do with its population. He described the diversity of peoples that are out there, clearly filtering the qualities of individuals by their race:

"The people that inhabit these extensive regions are composed of two diverse races ... Spanish and indigenous. In the countryside of Cordoba and San Luis the pure Spanish race predominates, and it is common to find in the fields, grazing sheep, girls that are so white, so pink and beautiful, like the elegant ladies of the capital would like to be. In Santiago del Estero the majority of the population in the countryside still speaks "quichua" [sic], which reveals their Indian origin. (p. 46) In the countryside of Buenos Aires the Andaluzian soldier is still recognizable, and in the city foreign last names predominate. The black race, almost extinct now, except in Buenos Aires, has left us zambos and mulattos, inhabitants of the cities, a link between the civilized man and the ignorant one ... From the fusion of these three families has resulted a homogeneous group, that distinguishes itself for its love of idleness and its industrious incapabilities ... Much of what contributed to the production of this disgraceful result must 
have come from the incorporation of indigenous peoples under

colonization." 120

Sarmiento traveled extensively, and indeed may have derived these definitions through keen comparative observations. Nevertheless, his racial bias is clearly depicted in his use of language: the sheep, representatives of civility through agriculture, depicted as "beautiful," "elegant," "white and pink" girls stand for the positive and clean industriousness of the untainted white Spaniard; the foreign last names manifest Sarmiento's belief in the civility of the metropole of Buenos Aires, as its link to the outside world shows the city's spirit of progress; "idleness" and "incapability" describe the Indian, and the use of the "quichua" Indian language clearly depicts a sign of feebleness. The view of the black man is not any more positive as Sarmiento later stated that their introduction to the Americas had "fatal" results. But the black man is not to blame for the downfall of the American character; instead the Indian carries the blame for his incapacity to work and total idleness which led to the importation of blacks to the continent in the first place. ${ }^{121}$

The Indian tainted the peoples of the Americas, and to Sarmiento

${ }^{120}$ Ibid., p. 46.

${ }^{121}$ Ibid. Historian Lourdes Martínez-Echazábal comments that the paradox posed by Sarmiento's approval of the black race, in comparison to the Indian race, is based on the notion that Argentina had a very small population of blacks and mulattos and therefore did not pose a "problem" for the aim to civilize the nation. Furthermore, Martínez-Echazabal states that most of the blacks and mulattos in Argentine history were concentrated in the city, which to Sarmiento "constituted the center of 'civilization' and 'progress;"' hence, by their very presence in civilized society they could not have posed a problem. See Lourdes Martínez-Echazábal, "Mestizaje and the Discourse of National/Cultural Identity in Latin America, 1845-1959," Latin American Perspectives (Vol. 25, No. 3, 1998, pp. 21-42), p. 25. 
Spaniards were no exception. "...The Spanish race has not been seen endowed with better predispositions as it has seen in the American deserts abandoned to its own instincts."122 Sarmiento implied that the Indian way of life affected these Spaniards, and created a new breed of white man who carried with him characteristics antithetical to civilization. This is the man of barbarism that he depicted in the central character of this work, Facundo. He represents a type of outlaw, a gaucho who lives by his own rules. Even though he is white (or mostly white) - Sarmiento suggested that the very influence of the Indian world view upon him created a conspicuous barbarism in this quintessentially rural Argentine character. Therefore, to Sarmiento, the gaucho became a prototype of cultural mestizaje where the simple interchange of cultural values in day-to-day life changed the character of the those involved in the interchange. The cultural influence of one group over another is one dimensional; the Indian was not seen as an adaptable human being, capable of accommodating and integrating the value system of whites. Instead, the Indian was seen as bastardizing the white with his influence, and hence changing the character of the white man to resemble a mixture of cultures that Sarmiento saw as despicable.

The contradiction is clear: although white civilization is so clearly superior to barbarism in the eyes of Sarmiento, it is not presented as strong enough to overcome the savagery of the open desert. Like Alberdi, Sarmiento believed that the conflict rested on the quality of white immigrants that had come to Argentina. The importation of northern European characteristics, would be the solution to end the savagery. He looked to the Scotch or Swiss to provide examples of orderliness to the

${ }^{122}$ Ibid., p. 47. 
nation, and in reference to the progressive English he wished for their extensive presence in the land, "It would be good to propose to England, just to see, how many yards of linen and pieces of muslin it would give to possess these plains of Buenos Aires!"123

Sarmiento not only sought whiteness, but a good whiteness. The nordic cultures were revered as he described their clean and orderly behavior, even in those living in the countryside, in comparison to the Spaniard that had been affected by the temperament of the plains (the Indian temperament). The nordic culture seemed more impervious to the Indian influence, and hence, more appropriate to building a pure civilization in Argentina.

The nomadic tendencies of the gaucho and Indian stood in the way of progress. "There cannot be progress without the possession of the land, without the city, which develops the industrial capacities of man and permits him to extend his acquisitions." way that Alberdi did. A place like Patagonia, where the uncivilized malón, caudillo, and gaucho prevailed, would become this open space.

FROM DISCOURSE TO ACTION: The Search for the Good Immigrant and the Eradication of the Savage

The work to fulfill the wishes of the discourse would be intense. The ultimate manifestation of this crusade was the active recruitment of good immigrants from Europe and the completion of the Conquest of the Desert in the latter part of the

${ }^{123}$ Ibid. 
nineteenth century. The call for quality immigrants to places like Patagonia was institutionalized as government and enterprise set out to attract good Europeans in the nineteenth and twentieth centuries. The enfiteusis law of 1812 instituted the notion of providing land to foreigners that came to Argentina. In 1826, under President Bernardino Rivadavia, a new law decreed the cession of lands to foreigners in order to create populations in the frontier. In 1875, under president Avellaneda, it was authorized under law, that the executive branch could promote immigration and colonization of national territory through concessions of land to each immigrant family of 100 hectares, and cash advances of up to 600 pesos to cover transportation to the properties and for getting established. ${ }^{125}$ The immigration and colonization law of 1876 sought to establish towns or colonies in the interior, or locations for industry. It would provide sections of land, transportation, and lodging (until the final destination was reached) for the first one hundred settlers of a colony. Loans would also be given to these new arrivals for food, housing, and labor tools. ${ }^{126}$

Regional interests in fomenting immigration also pushed for practical plans to bring good Europeans to the land. In La Rioja province, just north of the Patagonian territory, for instance, one official called for the development of appropriate irrigation systems as a way to attract "intelligent and laborious" immigrants.

"The provinces of Constantine and Argelia (Africa), were only sterile

\footnotetext{
124 Ibid., p. 50.

${ }^{125}$ See "Tierras Publicas y Colonización," pamphlet by Andrés L. Lamas (Buenos Aires: Gráfico de Gunche, Wiebeck, y Turtl, 1899). Document 1383: Informes de Relaciones y Memorandums, 18331899. Archivo General de la Nación, Fondo Julio A. Roca.
} 
deserts before French domination ... Intelligence overrode nature ... and those arid deserts are converted today into flourishing and rich populations: in La Rioja we can obtain if not better, identical results. ${ }^{127}$

Others felt that immigrants could be attracted to the open lands of the country by capitalizing on foreign conflicts. For instance, a gentleman by the name of F. de Basaldua suggested in 1897, in a memorandum to the government, that conflicts in the Basque country of Spain could be beneficial for the plan to populate the "desert." Basaldua explained that the Basques sought independence from an "ignorant Spain," and that they were "sober and hard-working" individuals. The Basques, according to Basaldua, were desiring to leave Spain in order to organize their independence. $\mathrm{He}$ recommended to the government that the time was ripe to seek those Basques to go to the territory of Chubut in Patagonia in order to populate the colony of Eskal-Berri. ${ }^{128}$ In an intimate note that follows these recommendations, Basaldua explained that this kind of operation would result in everyone "being happy: the Desert is populated; the capitalists are happy; the little Basque people are in heaven; and President Roca is acclaimed ..."129 This plan would bring revolutionaries that perhaps had no interest in settling down in Argentina, but who sought a temporary safe space in which to organize Basque dissent from Spanish rule. Basaldua, however, did not look at the

\footnotetext{
${ }^{126}$ La Ley de Octubre de 1878 , Ibid.

${ }^{127}$ See "Proyecto Para Colonizar La Rioja," memorandum written by Felipe Cassini, Archivo General de la Nación, Documento 78-79, Carpeta 1383, Fondo Julio A. Roca. Not dated, but sometime between $1833-1899$, according to the dates covered by this archival folder.

${ }^{128}$ See "Memorandum con Recomendaciones al Gobierno," by F. de Basualda (Buenos Aires: 4 December, 1897). Archivo General de la Nación, Carpeta 1383, Fondo Julio A. Roca.
} 
long-term plan of bringing and keeping immigrants to the territory of Chubut, perhaps believing that the place would be seductive enough to keep those Basques from ever wanting to return to Europe.

Another individual with interests in building the population of Chubut province worked in England. In a letter written in 1881, Miguel D. Jones explained that "good" English people were ready to make the move to Argentina. He explained that the successes of previous English immigrants to the territory of Chubut were well known among a group of citizens of Liverpool. He stated that Argentines should "rest assured that they are the highest quality people who will be industrious when they arrive." 130 The tone of the letter suggests that perhaps Mr. Jones worked on the promotion of Argentina among the English. He suggested a high level of success in this endeavor, and was clearly proud to report to the president that several groups of immigrants had decided to leave Liverpool for Argentina. ${ }^{131}$

The promotion of immigration not only involved regional and governmental interests, but private corporate interests as well. In 1899, for instance, La Empresa de Colonización y Esplotación [sic] Rural e Industrial de los Territorios del Sud (The Corporation for the Rural and Industrial Exploitation and Colonization of the Territories of the South), proposed to the government its own plans for fomenting immigration. The company submitted a proposal to the government to bring one million European immigrants to the newly conquered south (the Patagonia) over the

\footnotetext{
${ }^{129}$ Note written to "Mi General" (presumably Julio Roca) by F. de Basaldua (15 January, 1899). Archivo General de la Nación, Carpeta 1383, Fondo Julio A. Roca.

${ }^{130}$ See letter from England written to Julio Roca from Miguel D. Jones, 19 April, 1881. Archivo General de la Nación, Carpeta 1383, Fondo Julio A. Roca.
} 
term of fifteen years. Under this proposal La Empresa would also "oblige itself to introduce to the country one million immigrants, of all sexes and ages, from Europe that would meet the conditions ... of immigration laws." ${ }^{" 132}$ It is not altogether clear what the interests of this private corporation were. Nevertheless, we can speculate that they would bring immigrants to the country under contract from the government, and perhaps acquire a significant amount of money through the sales of farm equipment to immigrants. Perhaps they sought the immigrants as laborers for their own or their clients' industrial and farm labor needs. Whatever the interest it is significant that government officials were not the only ones seeking to build the immigrant population of the frontier, and that private interests also pursued the goal of bringing European qualities to Argentine territory.

The thinking that prevailed in the endeavors to populate the desert with quality white folks also worked in the campaign to eradicate the "savage" from Argentine consciousness. The Indian existed in the white imagination in the most grotesque way, and no objection existed toward his extermination. Rosas' first conquest of the land had not been successful, and only a second Conquest of the Desert would achieve this. Under General Julio Argentino Roca, the second conquest took place, and the Tehuelches lost control of the land, and would become disenfranchised from the dominant social order forever.

\footnotetext{
${ }^{131}$ Ibid.

${ }^{132}$ Proposal by Empresa de Colonización y Esplotación Rural e Industrial de los Territorios del Sud (Buenos Aires, 1899). Archivo General de la Nación, Carpeta 1383, Fondo Julio A. Roca. Translation by author of this thesis.
} 
The situation of the frontier had been tense until 1878, when Roca's movement established Argentine supremacy. Malones continued to torment the elite through their extensive knowledge of the land and their exceptional mastery of the horse. Military forts constantly expanded into Patagonia, but with relatively little success as soldiers were prone to abandon their assignments in the frontier lines. In the late 1850 's, for instance, the frontier soldiers of Buenos Aires province deserted their troops for lack of available food, adequate artillery, and appropriate clothing for the Patagonian weather. Furthermore, soldiers' salaries were delayed and the insecure housing available to the troops encouraged defection. ${ }^{133}$ The War of the Triple Alliance posed another conflict that kept the country from moving the frontier line further south. Between 1865 and 1870, Brazil, Uruguay, and Argentina fought Paraguay in a bloody territorial war that killed two-thirds of Paraguayans. The war took a toll on the Argentine military, directing the funds and manpower that could have been used in the conquest of the south into the northern conflict. ${ }^{134}$

Nevertheless, the petty battles that frontier soldiers and landowners fought with the Indians persisted. A number of peace treaties were signed between government authorities and caciques of enemy tribes in which food and cattle were provided by officials in exchange for Indian pacification and cessation of cow-raids. Although some tribes adhered to the treaties, powerful ones such as the Confederation of Cacique Namuncurá in the western part of Buenos Aires Province, and Cacique

\footnotetext{
${ }^{133}$ Walther, p. 307.

${ }^{134}$ Ibid., pp. 327, 354.
} 
Baigorrita's Indians, also in the western part of Buenos Aires, did not. ${ }^{135}$ They continued their malones and the control of valuable salt deposits in this part of the province.

To defeat the Indians Argentine officials would continue with their project to colonize the south. The Conquest of the Desert would start once again in 1876 after the military conflicts with Paraguay ended, and new decrees passed to begin funding the southern project. In October of $1875, \$ 400,000$ pesos were granted by the executive power to Dr. Adolfo Alsina, Minister of War, to execute his plan to expand the frontier. By the year of his death in 1877, Alsina's troops had gained over 56,000 square kilometers of Patagonian territory, and had managed to push several Indian tribes far west and south from Buenos Aires province. ${ }^{136}$

Alsina's successor as Minister of War was General Julio Argentino Roca. Prior to his tenure in the ministry, Roca was protector of the frontier, and was criticized for being too "soft" with the Indians. Military Colonel Alvaro Barros, for instance, denounced Roca's policies in a letter to the editor in La República critiquing Roca's tendency to make deals with the Indians of the Patagonia, "I affirmatively sustain that all Indians of the Pampas of the south are strictly united through common interests against us." Making pacification deals, according to Barros, was no job for "the chief of frontiers." ${ }^{137}$ Roca worked within a scope of pacification, and claimed that the Argentine "Far West" would be "free of savages through the pacific actions of

${ }^{135}$ Ibid., p. 370 .

${ }^{136}$ Ibid., pp. 381, 423. 
the farmer and rancher" of the country. He defended his stance through a comparison to the United States' problems in establishing peaceful frontiers; after all, "it took the US army 13 years to push back the Seminoles." ${ }^{\prime 138}$

However, because of political pressures, and perhaps because of his interest in the presidency of the nation, Roca clearly changed his perspective of the "Indian problem." Roca's stance became more aggressive in order to appease those that supported his role in the government. He saw Alsina's plan as simply defensive, lacking the offensive quality that would swiftly drive the Indians south of the Río Negro and Río Neuquén. ${ }^{139}$ Roca insisted that the south needed to be conquered expeditiously because "the savages ... destroy our principal source of richness and they impede us from definitively occupying, in the name of the law of progress and our own security, the territories which are the richest and most fertile in the Republic of Argentina." ${ }^{140}$ Acquiring a 1.6 billion peso budget from the government in 1879, Roca mobilized his troops and completed the second Conquest of the Desert. ${ }^{141}$

In the first stage of the campaign, General Roca personally led the troops into Patagonia, and between the months of April and July of 1879, he occupied the entire plains area south of the Río Negro and Río Neuquén, he assigned a governor to the

\footnotetext{
${ }^{137}$ Letter to the Editor. Carta al Director, La República, 25, 26, 27 June, 1876, Buenos Aires, Argentina. Archivo Nacional de la Nación, Fondo Roca, Folder 1391. Translation by author of this thesis.

${ }^{138}$ Letter to the Editor. Carta al Director, La Voz de Río Cuarto, 28 June, 1876. Archivo General de la Nación, Fondo Roca, Folder 1391. Translation by author of this thesis.

${ }^{139}$ Sarasola, Nuestros..., p. 275-276.

${ }^{140}$ Julio Argentino Roca, Buenos Aires, August 14, 1878, Speech to the National Congress, in Walther, La Conquista..., Annex Number 13, Mensaje y Proyecto del Señor Ministro de Guerra y Marina, General don Julio A. Roca, Sobre la Traslación de la Frontera Sur a los Ríos Negro y Neuquén. ${ }^{141}$ Felix Luna, Julio A. Roca-Series: Grandes Protagonistas de la Historia Argentina (Buenos Aires, Editorial Planeta Argentina, S.A.I.C, 1999), pp. $42-46$.
} 
Territory of Patagonia, established several forts that would later become viable towns, and recovered 500 whites who had been held captive among the Indians. ${ }^{142}$

Furthermore, he subjugated the Indians of the territory. According to the Department of War and the Marines Memoirs from 1879, five principal caciques were imprisoned, one principal cacique died, 11,784 Indians were imprisoned, 1,049 were converted to civilized behavior (through placement in reducciones), and 1,313 were killed. ${ }^{143}$ The rest of the Indians north of the conquered territory fled to the south of the Río Negro and Río Neuquén. ${ }^{144}$

The second stage of the conquest occurred after General Roca assumed the presidency of the nation. He sanctioned the continuation of the campaign in attempts to conquer the most "rebellious" caciques. By the $1^{\text {st }}$ of January, 1885 , it was believed that the last of the caciques succumbed with his resignation to the armed forces. With pride, the governor of the territory wrote to President Roca that “. ... it is an honor to manifest to the Supreme government and to the country ... that in the south of the republic all frontier limits with the indigenes have disappeared ... There is not a single tribe in the countryside that has not been reduced voluntarily or by force."145 The consolidation of the territories south of Río Negro into the Republic of Argentina took place in 1881 . The southern territory, threatened by Chilean interests in Patagonia, was divided when an accord between both southern countries gave

\footnotetext{
${ }^{142}$ Sarasola, Nuestros..., p. 281.

${ }^{143}$ Memoria del Departamento de Guerra y Marina, 1879, p. 6, in Walther, La Conquista ..., p. 488.

${ }^{144}$ Walther, La Conquista ..., p. 488.

${ }^{145}$ Note by General Vintter to the chief of state of the Military, 20 February, 1885. Memoria del..., in Sarasola, Nuestros..., p. 287.
} 
Argentina the final claim of sovereignty over the majority of the territory that stretched all the way into Tierra del Fuego. ${ }^{146}$

Approximately 2,500 Indians died in the Conquest of the Desert. ${ }^{147}$ But it must be noted that the death of these Indians was not solely manifested in this statistic; the loss of land, which essentially defined the cultural space in which the Indians operated for thousands of years, eradicated the possibility of a full indigenous recovery after this campaign. By surrendering their land, the Indians relinquished much of their identity as a group. The movement of "civilization" would not end with the battles of the late nineteenth century, but as we shall later see, it would continue with a systematic program of white infiltration into previous Indian territory.

In essence the conquest was the tangible realization of a discourse that had dominated the dialogue of the times. The discussion of the "Indian problem" in the Patagonian region had obsessed the colonial authorities and landowning circles. The preoccupation continued into the independence period with politicians' illusions of creating a nation that would surpass even the most advanced European nation in character, productivity, and honor. The momentum persisted as landowners, deeply involved in the power structure of the republic, sought to eradicate obstacles (Indians) to the growth of their estates. The advent of Julio Argentino Roca to presidential power established the rigid military mindset that would pose the necessary elements of a "successful" campaign to "clean" the problem that had been discussed for almost four hundred years.

\footnotetext{
${ }^{146}$ Luna, Julio..., pp. 67-68.

${ }^{147}$ Sarasola, Nuestros..., p. 287.
} 
The success of the campaign established the "clean canvas" that so many had wished for in their discourses. The progressive move to paint that canvas with the "glorious" whiteness of Europe could begin. Roca had fulfilled the call of Argentines who saw in the savagery of the frontier the obstacles to progress and civility. It was believed that "the tendency for young countries to adopt all innovations, no matter how hostile ..." was necessary in order to reach "true wisdom ... General Roca had proposed to himself consolidating [Argentine] nationality, and he achieved it." ${ }^{\text {,148 }}$ By the time Roca left office, in 1887 , he was perceived as the "best" president the country had ever seen for he embraced "the spirit of his times" by promoting "excessive progress and liberalism." 149 Roca's perceived success consolidated Patagonia as the embodiment of a "possibility" in which to build the wish for a proper national identity. The push for modernization in the frontier could finally begin.

148 "Terminación del Gobierno del General Roca," La Tribuna Nacional (Buenos Aires, Argentina, 1887). Archivo General de la Nación, Fondo Roca, Folder 1391. Translation by author of this thesis. ${ }^{149}$ Ibid. 


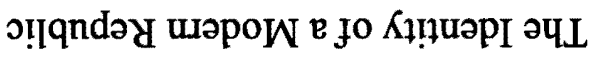
:УกOA УALdVHว 
After the conquest, Indians would perhaps "disappear" and be written into history as previous natives of the land, now long gone. The federal government believed that a social transformation of any remaining natives would be a swift process, promoting their "retraining" so as to use their best capacities within the model of the West. President Avellaneda, in a speech to the Chamber of Deputies during the conquest, expressed his confidence in the transition,

"The Indian is an excellent soldier ... He can be a good mariner ... The Indian is apt for all physical jobs, and the province of Tucumán has employed five hundred in its ... works. The women and the children have been distributed by the Benevolent Societies among the families." 150

Surely Indians could be incorporated into society, the government thought, as the superiority of civility would captivate them and inherently change them through the consistent work ethic and the Christian values of the whites. The consolidation of the nation, it was believed, would establish the paradigm under which all inferior cultural ways would succumb to a European type of everyday existence.

Within the analysis of the castas system or a political mestizaje, which sought to "whiten" native populations, native characteristics would diminish as Indian blood quantum became so trace (due to miscegenation with whites) that few mestizos would

\footnotetext{
150 "Mensaje del presidente Avellaneda al Congreso," In Felix Luna, Julio A. Roca..., p. 49, year unknown.
} 
even look or act like Indians. Perhaps this was the goal in Argentina, and it is very probable that due to the cultural adaptability of human beings, many Indians did integrate well into the emerging white societies, and may have even had children with whites or mestizos, integrating Caucasian characteristics into their offspring. As we will learn, however, the nomenclature of mestizo common in other parts of Latin America (and which suggested gradations of color), or "mixed-blood" common in the United States, is hardly noticeable in the data.

After the conquest people were separated into two categories: Indian and white. This suggests that no middle ground existed in people's perceptions of others; and that perhaps persons who were legitimate results of mixed-blood unions may have found themselves advantaged if they manifested more physical white characteristics than Indian ones; perhaps referring to themselves as whites. On the other hand, if such persons manifested more Indian physical characteristics, they would likely have been socially disadvantaged, and would have been classified as Indian rather than mestizo, therefore denying their white heritage. Such scenarios, described by anthropologist Carol A. Smith (see Introduction), affirm that class separations were often based on physical attributes and that racial profiling was often based on age-old racist myths that had never been overcome.

The union of whites and Indians into a mestizo culture within Patagonia is difficult to account for. Evidence that describes such a union that created mestizo progeny is scarce. Marriage records do not always reveal the race of those who married, and even if they did they would not necessarily say much about mestizo 
children — children could be born to unwed parents, single mothers, as victims of rape, or to prostitutes in the Patagonian frontier. Furthermore, the evidence does not allow us to tell whether or not Indians adopted institutionalized marriage as part of their acculturation, which would provide us with marriage certificates for our investigation. In addition, although church records might reveal the race of children that were baptized, the scarcity of successful proselytizing in the Patagonian area prior to the twentieth century would make it very difficult to locate such information.

However, I contend that mestizaje is not simply a biological result of biracial societies. Instead, it is a cultural phenomenon based on a rich diversity of practices, opinions, and knowledge. Within the analysis of a cultural mestizaje, marriage and birth certificates, although helpful, are not imperative to draw conclusions. In the following pages, my conclusions are based on census information that counterposes the popular imagination of mainstream Argentine culture. Through the data, I can affirm that a cultural mestizaje did exist in the Patagonia after the conquest, despite the prevalent discourse that suggested the eradication of the Indian in the frontier.

The data is not always conclusive, but nevertheless helps us answer some of the questions that remain: what really happened to the Indians of Patagonia following the conquest? did they integrate into a criollo society ready to relinquish all claims to their ethnic roots? If so, how did the process take place within a society that viewed the Indian as repugnant and savage? It is doubtful that the process of displacement and integration went smoothly. Furthermore, with the lack of support for mestizaje (as expressed in the discourses of Sarmiento and Alberdi who, instead, advocated 
immigration from the northern sectors of Europe) it appears that the Indian would have been more marginalized than integrated into Argentine society. The isolated Indian was socially disadvantaged and perhaps incapable of merging with other Indian communities in order to reproduce. Whether this was the plan or not, popular knowledge, even within academic circles and national discourses, suggested that the Indians did "disappear" after the conquest, and not just in Patagonia, but in most of Argentina. We will explore this phenomenon later on.

Behind the stereotyping in discourse is the reality that confirms an Indian presence in Argentina. This is not simply limited to the recent influx of indigenous and mestizo individuals from peripheral countries that have entered the republic in search of work, those individuals that many view as the lower quality immigrants that are "ruining" the country. ${ }^{151}$ Instead, the presence of Indians was a fact during and after the supposedly final conquest to eradicate all Indians in the late 1800 s. In Patagonia, this is confirmed by the information that census takers provided during the National Census of 1895. This event, almost a decade after the end of the Conquest of the Desert, challenges modern notions of Indians as newly arrived outsiders, and confirms that the tradition of the land, which so many have struggled to define, is based in the communities of Indians that survived five hundred years of attrition and conquest.

The census is not always accurate, and displays an element of subjectivity. Yet we are left with the opportunity to make conclusions that we can draw from our

${ }^{151}$ See next chapter for insights into such opinions 
knowledge of both historical fact and human nature, and with this we can create a discourse that supports a viable mestizaje in the Patagonian frontier based on the intermixing of peoples culturally and biologically.

In reviewing the National Census of 1895, I explored the data that was accessible to me from four regions of the Patagonia where the Tehuelches had once been prominent. They include the territories of Santa Cruz, Tierra del Fuego, Neuquén, and Río Negro (see figure 5). Each census document was filled out by hand by local residents or travelling census-takers. Some wrote commentaries that help us understand how Indians lived after the conquest, while others filled out each document with institutional precision, only providing the required information for each citizen.

The forms asked for name, gender, age, nationality, province or territory of birth (if Argentine), religion, marital status, occupation, land-ownership (if any), and number of children of each citizen. Furthermore, it asked whether the citizen was crazy (or had a number of anti-social behaviors), orphaned, or had a goiter. Many Indians can be identified in this census through the census-takers' indication of "indigenous" or "Indian" under the heading of religion, province of birth, or nationality. Others are identified by their names, such as "India Juana" or "Indigene José." I noted that to some census-takers ethnicity was a significant factor of each identity they registered. Unfortunately, most census takers did not identify individuals as Indians in any of their data. 
Within these forms certain clues tell us the likelihood of an individual being Indian or mestizo-this is found in the surnames that indicate a Mapuche or Tehuelche ethnic background, and also in the professions that many exercised. In the first case,

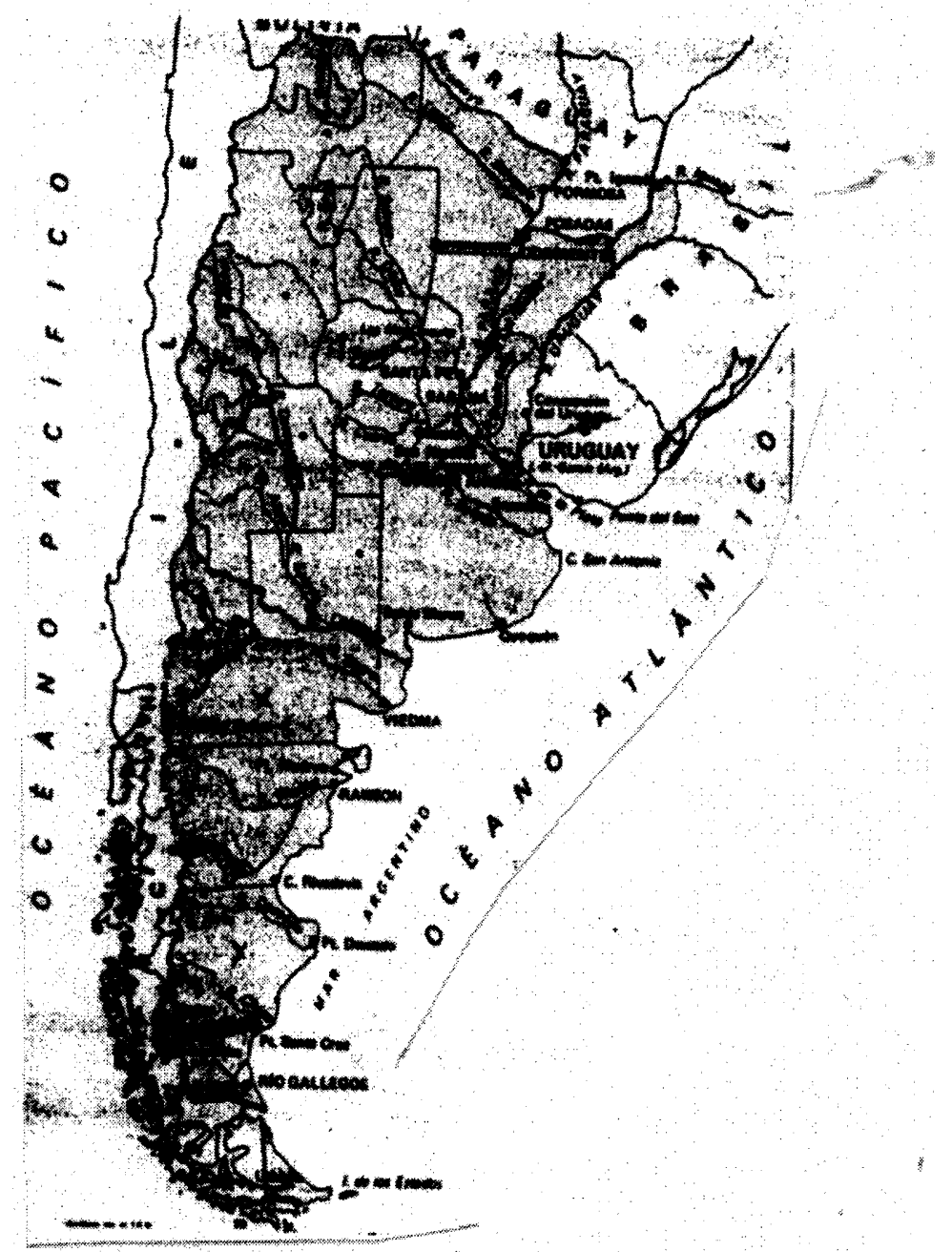

Figure 5. The territory covered by my census research includes the current provinces of Santa Cruz, Tierra del Fuego, Neuquén, and Río Negro. All are south of Río Colorado. From Manual del Alumno Bonaerense. 
Mapuche or Tehuelche names are very distinguishable based on some basic syllables and letter placements of their language. ${ }^{152} \mathrm{I}$ assume that these recognizable names are of people who are either fully or part Indian. However, it is important to note that in the majority of cases where people are identified as Indian, their surnames are Spanish and not Mapuche. Hence, we can also assume that in the censuses where Indians can only be identified by name, additional Indians or mestizos could be present but unidentifiable because of their Spanish last names. In essence, this makes my count of an Indian presence in Patagonia rather conservative, as I only count people specifically identified as Indian or people with Mapuche surnames as being part of the Indian population of the area.

Furthermore, it is uncertain whether or not census-takers reached all territorial inhabitants. For instance, some censuses were taken of mobile Indian camps, suggesting that other mobile groups could have been missed; furthermore, some data was collected from remote areas only identified by their location in relationship to a creek or a mountain, suggesting the possibility that other remote areas could have existed (with an Indian population), and were perhaps missed as well. This is unfortunate as my sense is that the percentages of Indians and mestizos in the area was much higher than what the data suggest. However, until a better indicator can be found, the data presented here will serve our purposes.

${ }^{152}$ See Ernesto Wilhelm de Moesbach, Diccionario Español-Mapuche (Siringa Libros: 1978); and research by Heinrich Puschmann, Universidad Católica de la Santisima Concepción, Chile, Department of Engineering, "The Nhewenh Mapuche Language Spelling" www.ict.uchile.cl/ hpuschma/mapuche 
In the second case, we can decipher Indian ethnicity through indicators of profession. For instance, some individuals not identified as Indians (and without Indian surnames), could be identified as indigenous by their practice of traditional and uniquely Tehuelche or Mapuche professions. Although these cases were few and did not affect the data significantly, I did count them as constituting the Indian and mestizo population of the area.

Finally, it is important to note that a large percentage of the people counted in the census were born in Chile. The percentage is not clear, but some towns were almost fully Chilean, while others were more than half. ${ }^{153}$ The ethnicity of Chileans is not known in most cases, unless they harbor a Mapuche surname. Nevertheless, this suggests that Chilean Indians and mestizos may have been present in the area, but were not identified as such by the census takers. This was very likely the case due to unguarded or open national borderlines, therefore raising the percentage of indigenous peoples present in the Patagonia after the Conquest of the Desert.

The census provides us with data that show significant patterns in the area which establish a space for cultural mestizaje. These patterns are the frontier economy of subsistence, miscegenation, the interchange or morals and values between cultures, and the sharing of the same space by different peoples.

\footnotetext{
${ }^{153}$ For instance, in Neuquén Territory, some areas had a $60-70 \%$ population of Chileans. See folios 69 -
} 75 , most of tomos $2,12,13$. 


\section{ECONOMY AND SUBSISTENCE}

A viable cultural mestizaje can be identified in this region through the economic activity and methods of subsistence that existed after the conquest. It is undeniable that a new economic paradigm was imposed in the frontier as new European arrivals established their livelihoods in towns and rural areas. Indeed, many haciendas owned by Europeans existed. Colonies of immigrants were commonplace as well. Subsistence patterns by these immigrants included farming, ranching, preaching, teaching, and small business ownership geared at meeting local needs. However, old subsistence methods continued after the conquest and they were practiced by both Indians and whites. One of the most prominent means of support was weaving and textile work. As mentioned in Chapter One, textile work was a lucrative part of Tehuelche and Mapuche sustenance. Women created wraps and throws that were not only sold on the market, but were used to clothe family members. ${ }^{154}$ The Araucanians had mastered textile weaving, and brought this art form with them when they araucanized the Argentine Patagonia starting in the seventeenth century.

According to the census, after the Conquest of the Desert, this art form continued among the Indians, as evidenced in the preponderance of tejedoras and

\footnotetext{
${ }^{154}$ Today, this continues to be an industry regulated by the provinces and their tourist boards. On a recent visit to San Martín de Los Andes, in Neuquén province, I noted that a local board of tourism maintained a shop of certified indigenous crafts, which primarily displayed elaborate and colorful textiles made by Indian artisans. On a visit to a Mapuche woman who lives on a ranch just next to Lake Huechulafquen, she showed me a rug that she was working on, and told me that she dyes her wool with elements she finds around her, particularly plants and roots. Visit to San Martín de Los Andes, Neuquén, and Parque Nacional Lanín (Lago Huechulafquen), July, 1999.
} 
hilanderas among the Indian groups. All of them were women, and it is very possible that many of them wove to clothe their children. Many women of child-bearing age were hilanderas or tejedoras including 30-year-old mother of two Indígena María, 28year-old mother of three María Segunda, 25-year-old mother of four Indígena Juana, or 28-year-old mother of nine Narcisa Yetuipan. ${ }^{155}$ Others were quite elderly and possibly continued their lifelong tradition of weaving as a method of subsistence and way to clothe their families. For instance, Rosa Callulef, who was 85 at the time of the census and had seven children, was a tejedora. Another woman by the name of Rosa Callulef, who was 70 at the time of the census and who had eleven children was a tejedora, as well as 90 -year-old Manuela Callulef who had nine children. ${ }^{156}$ In one area of the Territory of Neuquén, a district of 145 people had thirty Indians or mestizos, with fifteen women working as hilanderas. ${ }^{157}$ In another area of the territory, one district had twenty Indian hilanderas out of an Indian population of seventyseven. $^{158}$

It cannot be ruled out, however, that many of these women not only wove for themselves and their families, but also made a living from this craft. In a fully

\footnotetext{
${ }^{155}$ For Indígena María and María Segunda, see Censo Argentino, 1895 (from this point forward identified as CN 1895), Territorio de Neuquén, Tomo 16, Folio 111, Departamento $5^{\circ}$, Distrito $\theta$ (Archivo General de la Nación [from this point forward identified as AGN], Vol. 1378, Neuquén, \{in Family History Center, Salt Lake City Utah [from this point forward identified as FHC], Reel $0762388\}$ ); for Indígena Juana see CA 1895, Terr. de Neuquén, Tomo 8, Folio 53, Departamento $2^{\circ}$ (AGN, Censo 1895, Neuquén, Vol. 1379 \{FHC, Reel 0762388\}); for Narcisa Yetuipan see CA 1895, Territorio de Rio Negro, Tomo 2 , Folio 6 Partido de Avellaneda, Distrito de Cheforo Cuartel $4^{\circ}$ (AGN, Censo 1895, Rio Negro, Vol. 1386 (FHC, Reel 0760004\}).

${ }^{156}$ Interesting also is the fact that the younger Rosa is described as having a "goiter" in the census. It is not quite clear why this was significant, but possibly it was a way to identify people just like a scar is an identifiable mark. See CA 1895, Terr. de Neuquén, Tomo 16, Folio 115, Dept. $5^{\circ}$, Dist. $3^{\circ}$ (AGN, CA 1895, Neuquén, Vol. 1378 \{FHC, Reel 0762388\}).

${ }^{157}$ Ibid.
} 
indigenous area of Río Negro in the Districts of Caltranua, Ojo de Agua, Lagunta, Luemeco, and Quemeco, census-taker Felix Duberti made a mistake in his data that serves our purposes quite well. He included in the count ten men that were later crossed out of the census as being Chilean citizens. Duberti's mistake left us with the compelling information that these men were "merchants of textiles."159 It is very likely that the men, all between the ages of 18 and 51, were camping in this area during the census, while stopping during their business travels. Finding them in this area leads us to believe that they probably bought the textiles from Indian and mestizo women, and took them into the market, much the same way as it had been done centuries before the conquest within the frontier exchange system of the high Patagonia. We can also assume that the traders likely purchased the textiles with goods that were desired by the indigenous communities. If this is the case, then we can assert that the continuation of the textile trade continued to bring whites and Indians together into a shared arena that was based on economics. This was a process through which interchange inevitably brought people together and set the stage for mutual cultural influence, hence establishing the tools for a viable cultural mestizaje. The market was not the only source of mutual influence within the area of subsistence. Whites and Indians who shared spaces could learn from one another by watching each other's approaches to subsistence. This does not mean that they approved of the other's work, but nevertheless they were exposed to the activities of

\footnotetext{
${ }^{158}$ CA 1895, Terr. Neuquén, Tomo 13, folio 88, Dept. $4^{\circ}$, Dist. Pulmán (AGN, CA 1895, Neuquén, Vol. 1376 \{FHC, Reel 0762387\})

${ }^{159}$ See CA 1895, Terr. de Rio Negro, Tomo 11, Folio 56, Dept: 25 de Mayo, Dist: Caltranua, Ojo de Agüa[sic], Lagunta, Luemeco, and Quemeco (AGN, CA 1895, Vol. 1383 \{FHC, Reel 076005\})
} 
the other at some level. For the Indians the level of exposure was much higher, as they acquired many jobs that brought them into the new economic models of the area. For instance, the occupation of peón was quite common among Indian men, which suggests that they worked in white haciendas or ranches, and hence within a white paradigm of subsistence. Fifty-year-old Indio Ramon in Neuquén territory was a peón; and in Tierra del Fuego territory, William Fasiucanez and Charley Cushlana, among others, (all Yaghan-Fuegian Indians) were peons as well. ${ }^{160}$

Another profession that brought Indians into the white subsistence model was that of maid. In the Harberton District of Ushuaia, Territory of Tierra del Fuego, eleven-year-old Julia Shucaiago was a servant for the local ranching family; and in a rural district of the Territory of Santa Cruz 50-year-old India Addi, 40-year-old Indio Canié, and 28-year-old Indio Siking (all Tehuelches) were servants perhaps for the mestizo ranching family led by Araucanian Indio Paylan and his wife Maria Cisneros de Paylan. ${ }^{161}$

One Indian boy's job as a tailor brought him into contact with white communities. Fourteen-year-old Pascual Nahuelquil lived in the urban district of Viedma, in coastal Río Negro territory. He was one of only a few Indians that lived in the area populated by 643 people. ${ }^{162}$ The profession was not widespread among men

\footnotetext{
${ }^{160}$ For Indio Ramon, see CA 1895, Terr. Neuquén, Tomo 17, Folio 117, Dept.: $5^{\circ}$ Alercion, Dist.: $3^{\circ}$ (AGN CA 1895, Vol. 1378 \{FHC, Reel 0762388\}); for Fasiucanez and Cushlana see CA 1895, Terr. Tierra del Fuego, Tomo 1, Folio 4, Dept. de Ushuaia, Distrito de Harberton (AGN CA 1895, Vol. 1389 $\{$ FHC, Reel 076005\}).

${ }^{161}$ For Indian ownership of land, read on. For Shucaiago see Folio 4, Tomo 1 of Tierra del Fuego census; for all others, see CA 1895, Terr. de Santa Cruz, Tomo 1, Folio 10, Dept.: Santa Cruz al Norte del Rio (AGN CA 1895 Terr. de S.C. \{FHC, Reel 0760005\}).

${ }^{162}$ See CA 1895, Terr. Rio Negro, Tomo 16, Folio 76 a 80, Dept.: Viedma, Dist.: Viedma (AGN CA 1895 Terr. de Rio Negro \{FHC, Reel 0760005\})
} 
in Indian communities, so it is certain that he picked up the trade through his ingression into white communities, perhaps being himself a mestizo child.

With the exception of the textiles industry, the level of whites' exposure to Indian professions was minimal, and the likelihood that Indian modes of sustenance influenced the livelihoods of whites is very low. Nevertheless, some Indian professions persisted despite the push of the new, white-dominated subsistence models. A profession that continued among Indian and mestizo men after the conquest was the piñonero. This occupation involved the gathering of piñones, the seeds that fall from the araucaria tree along the high Andean forests. The seed is nutritious and versatile: it can be cooked in a variety of ways, or it can be turned into flour to make breads and other starchy foods. It was a central part of the diets of many Andean peoples before the conquest, and indeed continued to be so afterwards. In the Pulmán district of Río Negro, Fermin Curiau, Narciso Anastacio, Emilio Huesmenil, and José Pichaquén all declared "piñonero" as their profession. They lived in a district that had more than fifty percent of its population with Indian names, like Rosaria Nauncú, Carmen Pehuel, or Juana N. (India). ${ }^{163}$ Perhaps this is an indicator that an Indian community could be established in this district under old paradigms of subsistence in which piñoneros could continue to earn a livelihood, as we also see that 20 Indian women in this community continued their traditional Indian professions of hilanderas.

\footnotetext{
${ }^{163}$ CA 1895 , Terr. Neuquén, Tomo 13, folio 88. Another piñonero in the territory was Niculen, a 105year-old man who was born in the Central Pampas, an area without araucaria trees. He also figures as "handicapped" due to warfare. It is likely that he migrated west as the Argentine military moved into the territory. He lived his last years among a community of 80 Indians and mestizos. See CA 1895, Terr. Neuquén, Tomo 16, Folio 111.
} 
Furthermore, we cannot rule out the notion that those within this district, and other similar ones, with Spanish surnames were not also Indian or part Indian. As other parts of the census confirm, many people who were classified as Indian had Spanish surnames, therefore it is possible that in communities like Pulmán, the percentage of Indians was higher than what could be projected by the census indicators. ${ }^{164}$ This also gives weight to the notion that the Indian persisted and thrived after the Conquest of the Desert, although we still need more data to show how Indians and mestizos participated in the cultural encounters of Patagonia.

For the time being, we can look at other indicators of the cultural fusion that took place in the area, such as the Indian acquisition of white "jobs" or positions that traditionally went to whites. One of these is that of land owner which includes estancieros and hacendados. In Río Negro, for instance, 45-year-old Ramon Ancomiti was identified as Indian under the heading of "religion," and as an hacendado. Forty-two-year-old Pedro Olivera, identified in the same way, was also an hacendado. ${ }^{165}$ In Neuquén, Francisco Calaluf, 28, was an hacendado in a small rural district of 18 people. ${ }^{166}$ Also in Neuquén, thirty-year-old Francisco Namuncurá, who

\footnotetext{
${ }^{164}$ Spanish surnames are prevalent among certain Indians that are identified as Indian in the census. In the Pueblo District of Rio Negro, all people identified most indigenous have Spanish surnames including Marica Gallardo (age 50), Mariano Andrada (10), Pascual Torres (2), Maria Tejerina (33), and Andrea Basualdo (21); see CA 1895, Terr. Rio Negro, Tomo 9, Folio 50, Dept. General Roca, Dist. de Pueblo (AGN CA 1895, Vol. 1386 (FHC, Reel 0760004\}). In a rural district of Neuquén, out of 23 people identified as indigenous (from legible part of census), several also have Spanish surnames, including Juan de Dios Morales (age 1), Carmen Silva (70), Pablo Molina (40), and Carmen Vergara (20); see CA 1895, Terr. de Neuquén, Tomo 2, Folio 10, Dept. 1, Dist. $7^{\circ}$ (AGN CA 1895, Vol. 1376 \{FHC, Reel 0762387\})

${ }^{165}$ CA 1895, Terr. de Rio Negro, Tomo 1, Folio 1, Dept. de Avellaneda, Dist. Cuartel $1^{\circ}$ (AGN CA 1895, Vol. 1386 \{FHC, Reel 0760004\})

${ }^{166}$ CA 1895, Terr. Neuquén, Tomo 17, Folio 119, Dept. Neuquén, Dist. $5^{\circ}$ (AGN CA 1895, Vol. 1378 \{FHC, Reel 0762388\}).
} 
carried the surname of the famed nineteenth-century Indian warrior, was an hacendado. ${ }^{167}$ Travilan Granajo, who figured as "indigenous" under nationality, was 35 at the time of the census, was identified as "handicapped" by war, was an hacendado in Neuquén, and may have been married to another woman in the census who was indigenous, Maria de Granajo, 40 years of age, with 10 children. ${ }^{168}$ In Santa Cruz territory, Indio Paylan was identified as an Araucanian Indian, and he was a rancher. ${ }^{169}$ In Tierra del Fuego two Yaghan Tehuelche Indians were shown to own property, without any reference to how they used their property for a livelihood. ${ }^{170}$ Most interesting, is a case in Río Negro territory, where twenty-five-year-old Ramona Yusquetrán was an hacendada. ${ }^{171}$ This is compelling considering the few women that owned property during the times, and the even fewer numbers of Indians that owned property. She was also very young, and considering the few Indians that are noted among the area's 794 inhabitants, she may have inherited the land through a white parent or spouse that passed away, making her a mestizo. This is purely conjecture, but nevertheless this case, and all the others, pose a fascinating question as to how individuals that were supposedly of a low economic class acquired working property, and perhaps even came across capital.

Another typically "white" job was that of military or police officer, particularly in light of the fact that these workers were likely not on friendly terms with the

\footnotetext{
${ }^{167}$ Ibid., Tomo 16, Folio 115.

${ }^{168}$ Ibid., Tomo 15, Folio 105.

${ }^{169}$ CA 1895, Terr. Santa Cruz, Tomo 1, Folio 10

${ }^{170}$ CA 1895, Terr. Tierra del Fuego, Folio 4, Tomo 1

${ }^{171}$ CA 1895, Terr de Rio Negro, Tomo 13, Folio 67, Dept. de Viedma, Dist. General Conesa (AGN CA 1895, Terr. Rio Negro, Vol. 1383 \{FHC, Reel 0760005\})
} 
Indians, whom they had helped to drive out of their territories. In Río Negro, within a military fort, two individuals of seemingly Indian backgrounds (because of their Mapuche surnames) worked as "employees of the police." Lucio Nancañanca, 26 years of age, and Manuel Nemulpan, 30 years of age, worked in this role in the Second Fort of the Department of Avellaneda. ${ }^{172}$ In Neuquén, twenty-year-old Francisco Millapan, also carrying a Mapuche surname, figured as a "police agent" in a rural town of 61 individuals. ${ }^{173}$ Although ethnic identification of these individuals did not appear on the census, they had indigenous surnames and were likely to be at the very least mestizos.

Again, it is important to recall that Indian methods of subsistence did not influence whites as much as white methods of subsistence influenced Indians. However, whites were aware of Indian sustenance and formed opinions about Indians. Whether or not their conclusions were biased, in some form whites received information of Indian culture simply by their observations. White reflections of Indians appeared in the census, such as the case of census taker A. P. Rodriguez, a twenty-eight-year-old vigilant from the Sixth District, of the Fifth Department of Neuquén territory. In registering two individuals from a largely indigenous town, he described their profession as "passing life." 174 These two men, Gervasio Millanao, age 65, and Manuel Arogrinto, age 45, were apparently viewed by Rodriguez as living an idle life. The implications of such a commentary refer us to the historical white notions of savagery which describe the Indian as unwilling to work and tending to

${ }^{172}$ CA 1895, Terr. Rio Negro, Tomo 1, Folio 2.

${ }^{173}$ CA 1895, Terr. Neuquén, Tomo 16, Folio 116. 
spend too much idle time. Indeed, Mr. Rodriguez's commentaries may have represented a general misunderstanding of Indian livelihood by whites. Realistically, Caucasians operated under biased presumptions that likely kept them from inheriting the rich traditions of their indigenous neighbors. It is difficult to say whether newly arrived immigrants also carried those biases with them from Europe, but it is very likely considering the political environment that advocated separatism. However, I contend that whether or not the views toward Indians were biased, the influence of Indian behavior and practice had an influence on the consciousness of whites.

\section{MISCEGENATION}

People from the "old" and "new" worlds merged by virtue of their shared space. In terms of miscegenation, some clues from the 1895 census indicate that individuals of different ethnicities did have sexual contact. Some of these took place within long-term relationships, whereas others were short sexual escapades that resulted in mestizo children.

A number of mixed marriages can be noted in the data. Among them, is Pedro Olivera, who was mentioned earlier as an hacendado from Río Negro territory. He was a 42-year-old Indian man that was seemingly married to Segundina Olivera. She was a 36-year-old-Catholic woman married to Pedro for nine years at the time of the census, with four children by him, ranging in ages from two to twelve. ${ }^{175}$ The possibility that this was a mixed marriage is based on the notion that only Pedro is

\footnotetext{
${ }^{174}$ CA 1895, Terr. Neuquén, Tomo 16, Folio 111.
}

${ }^{175}$ CA 1895, Terr. Rio Negro, Tomo 1, Folio 1. 
classified as an Indian, whereas the rest of his family is not. Indio Paylan, an Araucanian Indian in Santa Cruz territory also appeared to be married to a nonindigenous woman. Maria Cisneros de Paylan was forty at the time of the census, ten years her husband's junior, and had three children by Paylan. ${ }^{176}$ Again, only he is identified as Indian whereas the rest of his family is not. The census does not confirm who is married to whom, but it does group people together through a loose indicator of those who live in the same household—mainly through a hand-drawn line that seemingly separates each household. Under those stipulations, and by the notion that the names of people like Pedro and Segundina, or Indio Paylan and Maria, are adjacent to each other on the list of household residents, then I can assume that these were "nuclear" families consisting of a husband, wife, and children. This would be particularly true in the Olivera household where Segundina's Catholicism would call for such a family structure.

The indicators of biracial relationships are scarce, but short term relationships may have had a different meaning in the area. The classification of "prostitute" under the title of "profession" is not widespread in the census. Hence, it is surprising to find one prostitute (out of a total of two that I noted in the census) that was Indian. In the First District of the Fourth Department of Neuquén territory, a prostitute by the name of Indígena Isabel, resided among a mostly non-indigenous population. She was 33years-old, single, and had six children. ${ }^{177}$ One hundred and two people lived in this district, and she was only one of two people classified as Indian, or even carrying an

\footnotetext{
${ }^{176}$ CA 1895, Terr. Santa Cruz, Tomo 1, Folio 10.

${ }^{177}$ CA 1895, Terr. Neuquén, Tomo 13, Folio 92.
} 
Indian name. It is hard to say whether she was a permanent resident of this town, but if she was it is likely that her children where the progeny of Isabel's sexual contact with the local non-indigenous men. Furthermore, seventeen male military officers lived in this town, fourteen of them unmarried, and perhaps she was a prostitute to serve this population. Moreover, she could be one of many indigenous women in the area that practiced prostitution as a mode of subsistence. New economic models in the old frontier may have pressured some indigenous women into adopting prostitution as a viable occupation to support their families, particularly among women who lost their families or tribal groups during the war and who did not have a chance to assimilate to other surviving Indian communities. The possibility exists that this was a way in which mestizo children were born after the conquest.

The data often leads one to make indefinite suppositions (although based on fairly strong data) of people's ethnicities. However, some cases of children's mixed ethnic identity can be confirmed in the area. In the Territory of Tierra del Fuego, we find the one case in which the census taker addressed the ethnicities of the Department of Thetis Bay as either fully Indian, fully white or mestizo. Only 26 people resided here, and three were characterized as mestizo: seven-year-old Juan Oilspelden, twoyear-old Benito Oval, and one-year-old María Larsen. ${ }^{178}$ The cases of young children who were the products of unlikely sexual unions are captivating, and not much can be said about how they came to be particularly in a small town such as this one. We do know that at the time of the census Thetis Bay's residents included eight marines, a Uruguayan writer, a Danish merchant, and eleven Indians or mestizos (most of them 
under the age of eighteen, with five of them under the age of ten). This was apparently a port town, perhaps a place for ships to stop on their way to other destinations. The presence of a writer tells us that it could also have been an adventurer's stop, as many of them traveled to Tierra del Fuego in the nineteenth century to write about the "ends of the earth." The town may have had a white population that often changed because of the professions that many of the white individuals held. Therefore we cannot explain the nature of the relationships between whites and Indians that resulted in mestizo children. One-year-old Maria Larsen, however, may have been the child of the Danish marine, Pedro Larsen. The 33-yearold was classified as a widower, and as there is no indication of who Maria's mother was, it could very well have been that she was dead; in other words, she was Pedro Larsen's deceased wife.

A small town like Thetis Bay may not be representative of an entire region, but the information it provides does contribute to the questions that are assumed for Patagonia. Did biracial children emerge as more whites moved to Patagonia? Did the tradition of mestizaje, that had begun with araucanization, continue into the beginning of the twentieth century? Is the southern cone mestizo?

The above examples are only a few that can be derived from the data. There is no saying exactly how many other mestizo children were born in the area, but it is likely that a significant percentage of new births gave light to children of Indians and whites. Furthermore, there is no knowledge of the gender division for parents of mestizos. In other words, who was more likely to merge with whites, Indian men or

${ }^{178}$ CA 1895 Terr. Tierra del Fuego, Tomo 1, Folio 1. 
Indian women? Considering the historical taboos associated with white women and men of color, it is likely that not many Indian men merged with white women. This being the case, mestizo children likely acquired most cultural characteristics from their mothers presuming they were the primary caretakers, hence continuing the lineage of Indian identity as a strong cultural indicator in the Patagonia. Of course, this is conjecture, as most data do not reveal this information, primarily because of the taboos against mestizaje, and the promotion of the idea that the Indian had been eradicated. However, as with most ethnohistorical analyses, we must take the risk of "imagining" what the situation was like in order to give credence to a history that many attempted to erase from popular memory. This certainly opens up the field to more research and more historical questions that need to be addressed in regards to the racial tensions of Patagonia.

\section{VALUE INTERCHANGE}

A third pattern that helps us note the mestization of Patagonia is based on value systems. Mestizaje is not simply about sexual contact, but, as I contend, it is a process of cultural interchange. As discussed earlier, this interchange took place within the economic and sustainability patterns of the area. Cultural reciprocity also took place in the arena of moral values.

Indigenous value systems were certainly more affected by white value systems than vice versa. This is certainly the case in the arena of religion, in which we can find examples of Indians who took on to the spiritual value systems of Western 
Europe. In a rural sector of Neuquén territory, for instance, we find that all the Indian/mestizo inhabitants are Catholic. Out of a population of 288, this area had 199 Indians or mestizos. ${ }^{179}$ This was a significant sector of the population, but it is questionable whether they were practicing Catholics, or simply integrated some Catholic traditions into their own spiritual life. As is the case in most of Hispanic America, Catholicism is a mixture of Christian values and native traditions, and the Patagonian Indians are no exception to this pattern. Indigenous Americans adjusted to the influx of Catholicism, with their own flair, creating syncretic belief systems that are manifestations of cultural mestizaje.

Protestant religions also had an impact in Patagonia. The Harberton District of Ushuaia, Tierra del Fuego was home to only one household owned by the Bridges Family from England. The household was a ranch which they owned, and all seven of the family members are classified as Protestants. ${ }^{180}$ Out of a total of 24 people in this ranch, fifteen were Yaghan Indians who worked as peons or servants to the Bridges family. All fifteen are classified as Protestants suggesting that they practiced their religion along with the Bridges. ${ }^{181}$ This is a unique case that suggests an unusual sharing of space in the Patagonia. To live in the same household, and practice the same religion, had to have an effect on the lives of both whites and Indians. Despite the notion that all were Protestant, it is clear that the Bridges had to have been

\footnotetext{
${ }^{179}$ CA 1895, Terr. Neuquén, Tomo 11, Folio 76 and 77 . No one in these two districts is identified as indigenous in the census, however the 199 people that I count as Indian/mestizo all have Mapuche surnames such as Railef, Pinchulef, and Colihueque. Another indicator of their ethnic background is the fact that not a single person, of the 199, has an occupation listed, and only five of them can read. ${ }^{180}$ CA 1895 Terr. Tierra del Fuego, Tomo 1, Folio 4.

${ }^{181}$ Ibid.
} 
influenced by the traditions of their Yaghan neighbors. The unequal balance of power is clear, as the Bridges were the owners of the ranch, and the Indians were their employees, but they likely exchanged food tastes, approaches to dealing with cattle, and perhaps even their language. Furthermore, some of the Bridges' employees owned plots of land, which suggests the existence of a much more neighborly scenario than in other districts of the southern cone.

\section{SHARED SPACE}

Despite the emerging economic and social standards that called for the establishment of ranches, farms, and civilized towns in Patagonia, many Indians continued to live in a traditional fashion. Tolderías were groups of houses resembling North American teepees or wigwams. Before the Conquest of the Desert, documentation shows that they were made with cattle or guanaco skins, and sewn together with horse or guanaco tendons. ${ }^{182}$ Several tolderias appeared in the 1895 census; this rejects the popular notion that the Indians had been eradicated during the conquest.

Census takers found a grouping of toldos in a fully indigenous district of Santa Cruz territory. Forty-six Indians lived here including four Araucanians, and 42 "Tehuelche-Argentines." All of them are identified by their first names, with the title "Indio" in front. Within the group was 60-year-old Indio Ojo de Pulga (Indian Eye of the Flea), and 2-year-old India Juana. The entire population lived in a total of nine

${ }^{182}$ See Cuneo, Estela, et. al. 
toldos. ${ }^{183}$ In Río Negro territory census-taker Alberto Morrell identified a mixed community of Indians and whites in which 116 out of 150 people were Indian, and 17 out of 31 households were toldos. He explained that they were built of guanaco, referring to the animals' skins. In one household, six people lived "in a toldo made of guanaco leather," including the elderly Rosa Fantastica (Fantastic Rose), of 100 years of age. ${ }^{184}$ Alberto Morrell moved on to two more districts in the territory where he found more tolderias. In the district of Luntruquice, Traeco, Icutch, and Choequemanuel, Morrell marked all 150 people visited as indigenous, and all lived in 21 toldos. ${ }^{185}$ In the next district, Morrell found an almost fully indigenous town in which all sixty one residents lived in toldos made of guanaco leather. Among the residents were 80-year-old Neriche Pinchifilo, and 90-year-old Maria Concherei. ${ }^{186}$ These examples give credence to the notion that Indians were able to maintain their communities despite the push to "modernize." Although some of these communities existed in isolation, as is the case in Santa Cruz territory, others existed within mixed communities that integrated toldos and European-fashioned homes. The existence of elders among the groupings maintained a link to historical traditions for the younger members of the community. This is important in the sense that Indian

\footnotetext{
${ }^{183}$ CA 1895, Terr. Santa Cruz, Tomo 1, Folio 9, Dept. Santa Cruz, Dist.: al Norte del Río, Población Indígena (AGN CA 1895, Territorio de Santa Cruz \{FHC, Reel 0760005\})

${ }^{184}$ CA 1895, Terr. Rio Negro, Tomo 11, Folio 53, Dept.: de 25 de Mayo, Dist.: Machinchegua, Nulhan, Catcataputa, and Luntruquile.

${ }_{185}$ Ibid., Folio 54, Dept.: 25 de Mayo, Dist.: Luntruquice, Traeco, Icutch, and Choequemanuel

${ }^{186}$ Ibid., Folio 55, Dept.: 25 de Mayo, Dist.: Choequemanual, and Runqueluan. Compelling in Morrell's data is the notion that a significant percentage of the tolderias' populations were people under age 25, or people who were born during the Conquest of the Desert or who were quite little during the war. This is a compelling indicator that Indian communities continued to thrive despite the government's push to "eradicate" them. Such evidence gives credence to the continuation of Indian lineages in Argentine populations either through mestizo or Indian progeny.
} 
cultural consistency worked as a deterrent against the white push to end "savagery." Hence, Indians subsisted within their own models of community even within the space that they shared with whites.

It must be noted that the tiny populations of these huge territories allowed for the isolation of many Indians and tolderias, and for the continuation of traditional lifestyles despite the Argentine government's claim to sovereignty over the area. Such isolation suggests that perhaps many Indians in the area were not accounted for in the census, again suggesting that the Indian was far from eradicated in Patagonia, and perhaps even thrived if isolated from the centers of military "intelligence."

The percentage of Indians and mestizos based on the sample from the four territories is rather low. Their total number in Santa Cruz territory out of a total population of 1,058 is 237 - this constitutes $22.4 \%$ of the population (although in some areas Indians constitute over $27 \%$ of regional populations). ${ }^{187}$ In the Territory of Tierra del Fuego, out of a total population of 477 individuals, 126 are Indian - this constitutes $26.4 \%$ of the population. ${ }^{188}$ In the Territory of Neuquén, out of a total population of $14,593,1,231$ were Indian, constituting $11.86 \%$ of the population. ${ }^{189}$ And in Río Negro, out of a total population of 9,296, 777 were Indians constituting

\footnotetext{
${ }^{187}$ This is based on a count from the Territory of Santa Cruz Census data that is available. It is very likely that the population of the territory was much higher, particularly the Indian population dispersed through this huge territory. However, it is likely that most census takers traveled to the more wellknown colonies to take the data, particularly to take count of all the new European settlements that had erected in the territory during the nineteenth century. See CA 1895, Territorio de Santa Cruz.

${ }^{188}$ CA 1895, Terr. Tierra del Fuego. The isolation issue is prevalent here as this is also a very remote territory. Furthermore, the totals are derived from the accessible data, and it is unknown how many people are unaccounted for.

${ }^{89}$ CA 1895, Terr. Neuquén.
} 
$8.4 \%$ of the population. ${ }^{190}$ However, the percentages cannot be taken as the definitive number of Indians and mestizos in the Patagonia following the conquest, but as conservative figures that simply show the continuation of a presence in the area. What is most significant is the level of influence between both whites and Indians as manifested by the examples articulated earlier. These show that people did share space with each other at a level in which cultural interchange was inevitable, and hence mestizaje in the area (which had begun centuries earlier with the araucanization of the Patagonia) continued well into modern times.

The examples above tell us that cultural reciprocity was not balanced in Patagonia —often times the influence of one culture over another was one dimensional with Indians acquiring many of the cultural traits of the whites, and whites not necessarily acquiring those of the Indians. The patterns do not show a level system of exchange, often suggesting that Indian assimilation into white culture took place, rather than cultural mestizaje. It must be noted, however, that the data is based on an official government report with its own biases and assumptions on issues of race and divergent cultures. If we assess the scenario of the old frontier we can note how old patterns of livelihood established by the Indian domain of the Patagonia continued to exist, and influenced the lives of white immigrants to the area. The continuation of a market for the crafts made by hilanderas and tejedoras is a case in point. We can also note this in the persistence of a cattle economy, a system established by Indians in the frontier, and adopted by immigrant newcomers as a viable way to make a living.

${ }^{190}$ CA 1895, Terr. Rio Negro. 
Moreover, we see it in the continuation of Indian communities and lifestyles despite the push to establish a white-paradigm of livelihood in the territories.

Cultural mestizaje must not be romanticized in Patagonia, or in most of Latin America. Individuals did not exist in harmony, nor did they willingly share their space. They were products of ethnic and cultural antagonisms that were established during the wars for the territory and in the discourses of national identity. Realistically, much of the Indian participation in the exchange of the new frontier was based on the need to survive, and not necessarily to integrate into a utopian "cosmic race."

Indeed, the class separation of whites and Indians is undeniable. In the cattle economy, for instance, whereas whites adopted the system that was established by Indians, Indians were displaced and lost most of their domain over herds or land. Whites controlled the elements of production in the area, placing indigenous men and women in subservient positions within the new economic and social structures. This imbalance of power was quite real, and continues today. Nevertheless, what is important here are the small scale exchanges (whether based on economic trade or personal confrontation) that occurred between peoples; the petty transactions between Indians, mestizos, and whites; the co-existence, whether peaceful or not, of diverse peoples within an emerging social structure. These are the events that I contend establish a cultural mestizaje, whether or not the events describe a harmony of coexistence. I contend that people who shared spaces also shared experiences with the 
inevitable result of creating an impact on the lives, perspectives, and values of others. This is where the reciprocity of culture took place.

Furthermore, although the population statistics for the four territories show that whites were more prevalent than Indians, we do see indicators that suggest the government's failure to include all Indians in the count. In addition, the situation complicates itself even more when we consider that many who may have been Indians or mestizos, were not classified as such because of the push to classify people by political nationality (instead of ethnicity), and the taboos against mestizaje. Very few Chileans for instance, were classified as indigenous, despite the fact that many were likely Mapuche who crossed the loose borderline of the Andes and set up their homes on the Argentine side.

A significant point is that more Indians survived the Conquest of the Desert than was assumed or promoted by government or popular media. The discourses that immediately followed the conquest addressed the success of the nineteenth-century writers' plans that longed for a clean canvas. The "success" in Patagonia proved the supremacy of the white national persona, and ousted all Argentine Indians (from both north and south) from a space in the national community. Continuing through today, we find that Indians are seen as only existing in the imagination of Argentines, and their modern expulsion from society is synonymous to the wish for ethnic purity that people like Sarmiento and Alberdi had had.

The Indian presence in Patagonia implies that the progeny of the Tehuelches and the Mapuche are among the people of Argentina today. The census shows that 
Indians survived and were not fully expelled from population-building. The descendants of the Mapuche and Tehuelches are among us, and we can see this in the faces of the people that carry even a small quantum of Indian blood in their bodies, and in the continuation of the class systems that since the arrival of the Spanish have placed people of color at the bottom of the economic scale. Whether or not modern national discourses teach us to reject this notion, the mestization of Argentina, as manifested in Patagonia is evident. 


\section{CHAPTER FIVE:}

Modern Perspectives and the

Indian Space in Society 
The myth of the non-existent Indian continued into the twentieth century. The discourse of race, historically based on a systematic prejudice toward the "savage" Indian, was articulated within academic and juridical circles, influencing popular opinion and myth. This rhetoric is an extension of the wishes of people like Sarmiento and Alberdi that called for good whiteness to develop within a clean canvas.

In the earlier part of the century, the Alberdi-Sarmiento paradigm of race was rearticulated by a prominent lawyer and sociologist, Carlos Octavio Bunge. He published one of his most influential books in 1903, Nuestra America, in which he devoted a lengthy discussion to the topic of mestizaje. ${ }^{191}$ Bunge asserted that "barbarian" mestizaje took place in Hispanic America because of the Spanish conquerors' "ethnic affinities." The affinities can be explained, among other things, by the "Carthaginian and Arabic conquest" of the Spaniards, and by the tropical climates which "predisposed [the conqueror's] temperament to connect with people so hot as were the Indian and black women."192 The "weakness" of the Spaniards in merging with indigenous women was not based on a European value system, but on the African influence over the Spanish. It is clear that, to Bunge, cultural flaws could not stem from the civilized world, but from outside influences that tainted the morals of good white folks.

\footnotetext{
${ }^{191}$ See Book II: "Indians, Blacks and Mestizos" in Carlos Octavio Bunge, Nuestra America (Barcelona, Spain: 1903). This is a 32-page manuscript of the second chapter in Bunge's work derived from the internet-based historical document site "Proyecto Ameghino" found at www. Argiropolis.com.ar/ ameghino/obras/buncar/cap2-amer.htm. Hence, pages for this work are not quoted from the physical manuscript but from web-based page numbers. .Many have called Nuestra America one of his most influential works.

${ }^{192}$ Ibid., p. 3
} 
In regards to Indian and white "hybridity" Bunge was adamantly opposed. Through a Darwinist analysis, Bunge suggested that Indians developed as a separate species of the same genus. To merge, he said, would result in biological atavism. To define this phenomenon he referred to Darwin's observations “. . . that if various pigeons of different varieties are crossed, these varieties lose the product of their distinct characters and tend to reproduce a type of ancestral wild species ... from which they all originate." 193 Bunge was concerned that if Darwin was correct, the merging of peoples of different species would take man back to a "primitive" age, "or at least one that is antiquated and pre-Christian." ${ }^{.194}$ Mestizaje, then, would make the people of the Americas regress to a prehistoric state seen as the antithesis of progress. The work of thousands of years of civilization-building would disappear through the "degeneration" of the racial refinement that history dealt to the whites.

Beside the general fear that Bunge instilled toward mestizaje, he insinuated a perception of the American mestizo based on physical characteristics and a psychological profile. This perception established stereotypes of "typical" characteristics assigned to the "hybrid" community. For instance, if in a family of ten children "nine have a European physical type and one a Negroid or mulatto [type], the first [nine] possess a European psychology; the last a mulatto one ... In one word, every physical mestizo, whatever his parents or siblings, is a moral mestizo."195 In essence, physique determines psychology, and no mestizo can be morally adept, even if brought up under what Bunge considered a civilized environment.

\footnotetext{
${ }^{193}$ Ibid., P. 15.

${ }^{194}$ Ibid., P. 16.
} 
This is particularly powerful in the discourse of everyday attitudes expressed among Argentines today. Physical perceptions make many see mestizos as cabecitas, and cabecitas are always "bad" by nature. They are seen as lazy, avaricious, criminal, and outsiders to established societal norms. Even within mestizo families that live their day-to-day existence within a European paradigm, their entrance into mainstream society is quite limited because of their physical attributes. ${ }^{196}$

Bunge influenced societal stereotypes of Indians and mestizos through what he referred to as their "generic characteristics" based on their "certain inharmonious psychology, ... relative infertility, and a lack of moral sense." ${ }^{197}$ The mestizo's first defect, according to this writer, was his or her rapaciousness. The mestizo had a certain "primitive fatalism that converts itself into apathy, his fierceness changes itself into an incurable greed." 198 Bunge viewed the malón, as discussed in Chapter Two, as the "fundamental sentiment, custom and institution of the wild and barbarous Indian ...," but the malón is "also the dominant passion of the civilized mestizo."199 Indians, were essentially viewed as rigid individuals who could not adapt to changes in social structures, and hence, would carry with them unrelenting 'savage' characteristics. As discussed earlier, this is clearly not the case, as Indians proved to be incredibly versatile in their adjustment to white social paradigms. This is not

\footnotetext{
195 Ibid., P. 17.

${ }^{196}$ See Margulis, La Segregación...

${ }^{197}$ Ibid., P. 17.

${ }^{198}$ Ibid., P. 22.

${ }^{199}$ Ibid. An interesting take in Bunge's discussion is his description of mulattos. Despite his acceptance of Spanish-Black miscegenation, mostly likely based on the notion that Spaniards had historically been infiltrated by Africans (Moors and Arabs), he is very direct in his psychological critique of blacks and mulattos. This is evidenced in words that he applies to them when analyzing their
} 
important in terms of the character of Indian culture in relationship to whites, but it shows that Bunge had little understanding of Indian character, and was extremely unqualified to make any psychological assessments of indigenous peoples.

The mestizo's "relative infertility" was perhaps Bunge's attempt at reassuring his compatriots that mestizos would not pose a full threat to civilized society due to the biological tendency of white-Indian "hybrids" to not be able to reproduce well. ${ }^{200}$ Hence, Bunge implied that history and biology decides who is "good" and "bad." By his very aversion to mestizaje Bunge expressed his desire to manipulate the course of history by advocating the prevention of the union of peoples who would act against nature by mating. “... Every normal man, after so many centuries of Christian ascendancy, is born with inherited aptitudes for distinguishing the good from the bad. Only degeneration can erase [these aptitudes], producing antisocial atavistic types." ${ }^{201}$ The mestizo is ahistorical, antithetical to civilization, and is a physical manifestation of everything bad to the status quo. Despite this biological threat to the civilized world, Bunge reassured his compatriots that it is within their means to prevent the course of the mestizo's erroneous place in history by ousting him or her from society, and hence preventing Indian blood from entering the bodies of the "good" European race.

Morality, suggested Bunge, is a trait that takes ages of evolution in a particular species. The "inherited aptitude" of what is good and bad, is absent among Indians as they are not well adapted to Christian value systems. Indigenous peoples, therefore,

psychological profile: impulsive, fake, petulant, vindictive, parasite, opportunist, libertine, antisocial, degenerate, and "irritable like a woman." PP. 21-22.

${ }^{200}$ Ibid., PP. 18-20.

${ }^{201}$ Ibid., P. 20. 
"lack all moral sense." In their aptitudes for governing themselves, Bunge explained, they do so with "blood and robbery." When it comes to their sexual morals, he continued, they have the blood of tropical climates, "of polygamist regions," compared to the good blood of peoples from colder climates that have a higher propensity toward monogamy. "The colored masses are, ... for ethno-climactic reasons. . . less 'virtuous' than the whites." ${ }^{, 202}$ Lack of morality, therefore, was further reason for whites to omit contact with Indians, not to mention reproducing with them. A mixed-race child would acquire the amoral qualities of Indians, and could not possibly, unless he or she "looked" white, be virtuous enough to belong to the dominant social structures.

Argentines answered Bunge's call to undo the perceived choke-hold that people of color had over the identity of the Americas. They "kicked out" the Indian from the national character as evidenced in the discourse of everyday interchanges and the rhetoric that makes the Indian "invisible" in Argentine nationality. A case in point is the promotion, beginning in 1913, of the poem Martin Fierro ${ }^{\star 2}$. In an institutional attempt to educate people about race, poet Leopoldo Lugones promoted José Hernandez' poem as the foundation of Argentine traditionalism in front of an audience that included the president of the nation, Roque Saénz Peña. ${ }^{203}$ Following the mass

\footnotetext{
${ }^{202}$ Ibid., PP. 20-21. So sexually immoral were colored Hispanics that Bunge says, "At one point it was discussed in Rome if per exception marriage should be permitted among the Hispanic-American Catholic clergy, whose members, at least in the warm countries, tend to carry abundant and ticklish African or indigenous blood in their celibate veins."

* Martín Fierro, an epic poem written by José Hernandez in 1874, depicts the life of a gaucho in the plains of the Pampas.

${ }^{203}$ See Maristella Svampa, "Inmigración y Nacionalidad: El Caso de Argentina, 1880-1910," Studi Emigrazione/Etudes Migrations (Rome, 1993: Vol. XXX, NO. 110), pp. 289-310. Svampa explains that Lugones's presentation was the culmination of a larger move that sought to assign to Martín Fierro
} 
immigration of laboring Europeans, instead of the enlightened individuals of northern white stock that Alberdi and Sarmiento had envisioned during the nineteenth century, Argentine officials struggled with the identity question once again and sought the creation of a tradition that could counter the lower class immigrants that arrived to the republic. ${ }^{204}$ Lugones established the mythical gaucho in Argentine identity by suggesting that this character revered courtesy, was melancholic, elegant, frank, loyal, and gentlemanly. ${ }^{205}$ In essence, Martin Fierro romanticized the tradition of the frontier by removing the "savage" traits that had by definition embodied the gaucho up until the early twentieth century.

According to historian Maristella Svampa, Lugones' promotion of Martin Fierro "consolidated definitively the mythical place of the gaucho" in Argentine nationalism. ${ }^{206}$ Lugones picked the poem that perhaps least represented the "traditional" gaucho, typically a renegade from civilized society who would often associate himself with the savages (who were often Indians) if he wasn't Indian or mestizo himself. Svampa explains that, "the gaucho that Lugones gives back to us has to do more with the 'singer' gaucho ... than with the hoards of savages that would back up the caudillos ... He is the solitary singer that anonymously roams through the Pampas."207

\footnotetext{
the manifestation of a traditional Argentine character. Svampa contends that an elite presence during this presentation embraced the insinuations of Lugones. All translations by author of this thesis.

${ }^{204}$ Ibid., Svampa contends that through this juxtaposition, an anti-immigrant sentiment was suggested.

${ }^{205}$ See Leopoldo Lugones, El Payador (Buenos Aires: Centurión, 1944).

${ }^{206}$ Ibid., p. 304.

${ }^{207}$ Ibid., P. 305.
} 
At the time of his presentation, Lugones served his contemporaries' search for a folkloric rhetoric that would press a xenophobic agenda. But Lugones' work eradicated the Indian from the collective memory of Argentines by promoting a false history of life in the frontier. During the "crisis" of immigration, the population, it was believed, needed to be given a character that they could hang on to as a representation of a long-gone past that was heroic and lyrical. The myth of the "good old days" was brought to the imaginations of many through Martin Fierro. This fed the societal perception that Indians did not exist in Patagonia, and that if they ever did they were eradicated by the Conquest of the Desert, and hence fully omitted from a significant national tradition. This gave further impetus to the notion of Indian as representing an "other" to the collective character of society.

As the twentieth century progressed, the promotion of the mestizo or Indian as "outsider" to national identity continued. We find the evidence in politics, education, literature, academic circles, the media, and everyday conversations. Some forms of exclusion are more intolerant than others, but in general most expel the Indian from the collective consciousness. In the 1940's, for instance, President Juan Domingo Perón instigated the nomenclature that would separate non-whites from society. $\mathrm{He}$ assigned the name of cabecita negra to the Indians or mestizos of the country to separate the "lower class" dark individual that adhered to his political philosophy from the white porteño that generally rejected him.$^{208}$ The name literally means "little

\footnotetext{
${ }^{208}$ See David William Foster, Buenos Aires: Perspectives on the City and Cultural Production (Gainesville: The University Press of Florida, 1998), p. 5.
} 
black head," possibly based on the bird that carries the same name. ${ }^{209}$ It is a pejorative connotation to the indigenous person that was widely adopted by the middle classes, and continues to be used in everyday language today. ${ }^{210}$ Such designation of mestizos established the categorization of people according to physical features that Carlos Octavio Bunge had called for earlier in the century; the physical body manifested the differentiation between an Argentine national and an "outsider," no matter what the citizenship of the individual.

In the field of education the treatment of Argentine indigenes is less biased. Nevertheless, the lack of curricular material on native history, particularly in regards to post-Conquest of the Desert Argentina, is noticeable. In an elementary school text that I used in sixth grade, the mention of Indians is limited to their presence during the colonization, and to their bellicose nature as Argentina acquired the territories of the south. The text taught me that Julio Roca "... conquered the Indians definitively," and that, after the conquest, dealings with the "brazen" Indians were "concluded." 211 Of course, elementary textbooks are not the best source for learning history. Nonetheless, they are powerful tools as they are more commonly accessible to the population than an academic paper on race relations. Such information can establish stereotypes in children and adults that legitimize the myths of national identity and promote their continuation.

\footnotetext{
${ }^{209}$ Carduelis Magellanica is a bird with a yellow body and a black head. See Guia de Aves Silvestres de las Facultades de Agronomia y Ciencias Veterinarias by Norberto Montaldo and Juan Claver. University of Buenos Aires, College of Agronomy, 1986. www.agro.uba.ar/agrohtm/aves/lista.htm ${ }^{210}$ See Mario Margulis and Marcelo Urresti, La Segregación Negada: Cultura y Discriminación Social (Editorial Biblos, Buenos Aires, 1998).

${ }^{211}$ Manual del Alumno Bonaerense: $6^{\circ}$ Grado (Buenos Aires, Editorial Kapelusz, 1979) pp. 227-229
} 
At a higher academic level, the mention of Indians is limited as well. For instance, a very modern population study alludes to the "invisibility" of Indians in Argentina. Scholar Rosario Güenaga discusses the population-building of the Patagonian province of Santa Cruz, and states that at the turn of the twentieth century the province was unpopulated, except for the Indians. Nothing else is mentioned of this Indian presence throughout the entire study, excluding the Indian significance to this territory. ${ }^{212}$ The implication is that Indians stand outside the model of the national and desirable populace, despite their documented presence in the area before and after the conquest.

History books also fail to capture the importance of Indian-white relations in the country. A general Argentine history that was published in the United States, for instance, only mentions the Conquest of the Desert once, and the interaction of whites and Indians as a "city vs. country" phenomenon. ${ }^{213}$ The events in Patagonia seem irrelevant to historians in a similar fashion to the notion of Western history within United States historiography. The implication is that the point of departure for analysis must be the nation-state, and the move toward territorial conquest is simply a byproduct of this history. Western historians, as well as myself, would argue that this is a limited perspective which does not take into account the complexity of events (including events related to race) that began in the frontiers and moved toward the nation-states. The implication is that history is one-directional, and that the

\footnotetext{
212 See Rosario Güenaga, "La Conformación Social de un Territorio de Inmigración," Revista de Indias (vol. 56, no. 206, 1996), pp. 257-266.

${ }^{213}$ See David Rock, Argentina, 1516-1982: From Spanish Colonization to the Falklands War (Berkeley: Univesity of California Press, 1985).
} 
happenings of territories dominated by Indians cannot contribute significantly to our understanding of history.

In the latter part of the twentieth century, however, some authors dedicated their works to the Conquest of the Desert. Arguably, the most comprehensive work on the conquest is Juan Carlos Walther's La Conquista del Desierto: Lucha de Fronteras con el Indio (The Conquest of the Desert: Fight with the Indians over the Frontier) published in $19700^{214}$ The author was a military historian and wrote mainly about the principal military operations of the conquest. His view of the Indian is quite antagonistic; he often refers to the brazen nature and uncultured behavior of the native. He reasserts throughout the work that the Indians were fully conquered and he ignores their significance to the population of Patagonia after the conquest. Again, this implies that Indians have little space within the consciousness of national history, and if they do, it is simply as a peripheral group with little good to contribute to society. This prejudice is not just geared toward Indians, but is a manifestation of a greater problem of race geared toward anyone embodying an "otherness" to the myth of national identity. It is as if even modern day Argentines embraced the SarmientoAlberdi paradigm, whatever their level of education. For instance, jokes and commentaries about Jews and cabecitas abound in places such as soccer stadiums within the cheers that put down ethnic groups. Sociologist Lorena Edelstein explains that most of these jokes are based on the exclusion of ethnic groups from belonging to the Argentine nationality. She explains that for the most part they suggest the

${ }^{214}$ Juan Carlos Walther, La Conquista del Desierto: Lucha de Fronteras con el Indio (Buenos Aires: EUDEBA, 1970). 
illegitimacy of non-Christians and people of color within the social paradigm. The jokes suggest that Jews belong in Israel, or that cabecitas are from Paraguay or Bolivia and live in Argentina illegally. ${ }^{215}$ In essence, the jokes are a manifestation of a general and accepted consciousness that rejects the existence of a diverse Argentina. This makes it difficult for most citizens to exert an acceptance of multi-culturalism for fear of being ousted from a mainstream society that shows itself to be racist.

Finally, my own interactions with friends or colleagues have led me to the conclusion that mestizaje is taboo in Argentina. It is not uncommon to go to a corner store anywhere in the country and engage in a discussion of the state of affairs in the country with the butcher or with a fellow shopper. The question, "Do you know what the problem with this country is?" seems to resound from people's mouths in cafés and kiosks where strangers interact to figure out why the country is plagued by problems. Somehow, many people blame the situation on the quality of people that live in this vast nation. On a recent visit to the grocery store, the owner told me that the problem lies in the quality of immigrants that are now arriving into the country, "It used to be that good people from Europe would come to Argentina, and they are the ones who put all the labor into building up the country. Now all you see are these cabecitas coming to our country and they are ruining it for everyone." ${ }^{, 216}$ A friend, well-educated and working in an administrative post at the Department of Education,

\footnotetext{
${ }^{215}$ An example of a joke that excludes persons from national identity and legitimacy is: "Stranger than a Peruvian with immigration papers." On jokes, commentaries, and songs see Lorena Edelstein, "E1 Chiste y la Exclusión: Aproximación Sociológica a los Chistes Discriminatorios," in Mario Margulis and Marcelo Urresti, La Segregación Negada: Cultura y Discriminación Social (Buenos Aires: Editorial Biblos, 1998), pp. 265-275.

${ }^{216}$ Conversation with owner of Los Galleguitos grocery store in Mar del Plata, 1999.
} 
echoed the sentiment during another conversation I experienced, in which she affirmed that the "damn Indians from Bolivia and Perú" have created the crime sprees and advent of slums in the city. The notion of an Indian presence is still seen as an "otherness" to Argentina. An Indian could not possibly be Argentine, furthermore he or she could not possibly be a decent human being.

The Indian as an "outsider" to national identity is a concept that the discourses of the nineteenth-century instituted. The perception continues well into the twenty-first century, therefore giving the attempt to eradicate the Indian from the collective memory a high level of success. The discourse of mestizaje, therefore, finds an unreceptive audience in Argentina where "whiteness" is so revered that the space for a multi-ethnic analysis of the population is minimal. 
anDOTIdA 
"Mestizo Argentina" should not be an anomalous phrase. The cultural influence of Indians and whites over each other is evident in this country, and not simply one-dimensionally. Many Indians adapted to white society, but this does not imply that they have culturally assimilated and hence renounced their Indian heritage. The dominant social paradigm is indeed established by whites, and to exist outside of it (i.e., maintaining one's Indian traditions) can mean isolation and exclusion from the community at large. However, this may not be enough to drive Indians and mestizos to abandon their traditional lives and practices. Some continue to live in their original spaces, practicing "archaic" methods of subsistence, despite the labeling that society gives them of "outsiders." ${ }^{217}$ The national community, however, adopted many of the traditions of the Indians into their own cultural realms, including the musical instruments played by popular folklore musicians, the national obsession with drinking mate, the syncretic religious practice of worshipping Latin American virgins (as in the Virgin of Luján in Buenos Aires province), the acceptance of curanderas and their remedies who often practice traditional Indian healing methods, the popular practice of buying from Indian women at market for their honesty and eye for quality, the embrace of Indian musical icons such as Mercedes Sosa or Atahualpa Yupanqui, and the list continues. ${ }^{218}$ Whites absorbed many characteristics of Indian culture

\footnotetext{
${ }^{217}$ Indian associations, such as the Asociación Indígena de la República Argentina (AIRA), currently advocate for the sustainability of Indian hunting grounds, and for the constitutional rights of Indigenous peoples within the modern governmental entities. See Horacio Maldonado of AIRA "Los Derechos Constitucionales de los Indígenas en Argentina y la Explotación de la Biodiversidad," speech from the International Workshop on Technical, Cultural, Political, and Legal Aspects of Bioprospecting in Argentina, 1996.

${ }^{218}$ Mate is an indigenous drink that is very social (much like the sharing of a peace pipe), originating in Paraguay. It is drunk in Paraguay, the southern part of Brazil, Uruguay, some parts of Chile, and in most of Argentina. Drinking mate is an indigenous practice widely adopted by mainstream Argentine
} 
which suggests that Indians did not simply assimilate into white society, but that Indians and whites have had a reciprocal cultural relationship despite the intellectual move to denounce the native heritage.

Mestizaje, therefore, should be a point of departure for the analysis of national identity and history. Despite the words that have expressed the wish for a white canvas, the blend of ethnicities is not just evident in cultural exchange, but it is evident in people's faces and within the very rejection of "otherness" within white society. Cultural and ethnic mixture is the phenomenon of living in the Americas; peoples from all over the world have congregated here to form a society so diverse and so unique that the historical quest to build this continent only from the models of the "Old World" is almost futile. The Americas are diverse, and history should explore how it came to be because of its different cultural components. Argentine historiography needs to address mestizaje within the mainstream in which sixth grade students learn about historical and present diversity, sports aficionados understand the hurtful nature of racist cheers, and corner store butchers realize that their Argentine clientele is made up of all types of people.

Within limited academic circles the challenge of changing the racial discourse is slowly being met. Scholars such as Mario Margulis, and Victor Ramos study racism in Argentina and published captivating works on the topic at hand. Indeed, this is a beginning toward changing attitudes about mestizaje and multiculturalism, and will perhaps lead to a reassessment of national identity based on diversity.

culture. See Francisco N. Scutellá, El Mate: Bebida Nacional Argentina (Buenos Aires: Plus Ultra, 1989). 
Nevertheless, the challenge must be carried to the mainstream in order to give the people of the country a true consciousness of where they live, and the tools with which to build a society more egalitarian and prone to justice.

Mestizaje implies a richness of perspectives and attitudes that can give a people a broad comprehension of their existence and purpose as a group. This is an advantage for any society or individual. To embrace such human richness is essential to release the chokehold of discrimination that for so many centuries failed to recognize peoples with unique and worthy contributions to society. 


\section{BIBLIOGRAPHY}

Alberdi, Juan Bautista, Bases y Puntos de Partida Para La Organización Politica de La República Argentina (Buenos Aires, Ciudad Argentina Editorial de Ciencia y Cultura, 1998).

"Archivo de Sintesis de los Datos del Censo '91," published by Instituto Nacional de Estadistica y Censos (INDEC), Ministerio de Economía, Obras, y Servicios Publicos, Secretaría de Programación Económica y Regional.

Axtell, James, The Invasion Within: The Contest of Cultures in Colonial North America (New York: Oxford University Press, 1985).

Basualda, F., "Memorandum con Recomendaciones al Gobierno," (Buenos Aires: 4 December, 1897). Archivo General de la Nación, Carpeta 1383, Fondo Julio A. Roca.

Bonfil Batalla, Guillermo, Mexico Profundo (Austin: University of Texas Press, 1990).

Bunge, Carlos Octavio, Book II: "Indians, Blacks and Mestizos" in Nuestra America (Barcelona, Spain: 1903).

Canals Frau, Antonio, Las Poblaciones de la Argentina: su Origen, Su Pasado, Su Presente (Buenos Aires: Editorial Sudamericana, 1953).

Censo Argentino, 1895, Territorios de Neuquén, Río Negro, Santa Cruz, and Tierra del Fuego, Family History Center, Salt Lake City Utah (Reels 0762388, 0760004, 0762387, 0760005).

Clarin, Buenos Aires, July 14, 1995.

Clarin, Buenos Aires, April 26, 1998.

Covington, James W., The Seminoles of Florida ( Gainesville: University Press of Florida, 1993).

Cúneo, Estela M., Luz María Font, and Gladys Varela, "Encuentros y Desencuentros Entre Dos Sociedades. Pehuenches y Conquistadores en el Neuquén del Siglo XVIII," in Estela Cúneo, et. al, eds., Los Hijos de la Tierra: Algunos Capitulos de la Historia Indigena del Neuquén (San Martín de Los Andes: Dirección Municipal de Cultura, Municipalidad de San Martín de Los Andes, 1998).

De Basaldua, F., Note written to "Mi General" (presumably Julio Roca) (15 January, 1899). Archivo General de la Nación, Carpeta 1383, Fondo Julio A. Roca. 
De Moesbach, Ernesto Wilhelm, Diccionario Español-Mapuche (Siringa Libros: 1978).

De Ulloa, Jorge Juan and Antonio, "Discourse and Political Reflections on the Kingdoms of Perú," ca. 1749 (in Emory University's Culpepper Project: Colonial Latin American primary documents, www.emory.edu/COLLEGE/CULPEPER/BAKEWELL/texts/juanandulloa.html).

Dussel, Enrique, $A$ History of the Church in Latin America: Colonialism to Liberation (1494-1979), $3^{\text {rd }}$ ed., trans. by Alan Neely (Grand Rapids, Michigan: William B. Eerdmans Publishing Co., 1981).

Edelstein, Lorena, "El Chiste y la Exclusión: Aproximación Sociológica a los Chistes Discriminatorios," in Mario Margulis and Marcelo Urresti, La Segregación Negada: Cultura y Discriminación Social (Buenos Aires: Editorial Biblos, 1998).

Exhibition of the War of the Desert, Museum of the Patagonia "Francisco P. Moreno," Administration of National Parks, Office of Nahuel Huapi National Park, Río Negro, Argentina, 1999-2000 Exhibition.

Font, Luz María, and Gladys Varela, "El Neuquén Indigena de los Siglos XVIII y XIX," in Gladys Varela, et. al., eds., Los Hijos de la Tierra: Algunos Capitulos de la Historia Indigena del Neuquén (San Martín de los Andes, Argentina, Dirección Municipal de Cultura, Municipalidad de San Martín de los Andes, 1998).

Font, Luz María, and Gladys Varela, "El Poblamiento del Neuquén desde sus Orígenes a la Llegada de los Españoles," in Estela Cúneo, et. al., eds., Los Hijos de la Tierra: Algunos Capitulos de la Historia del Neuquén, (San Martin de Los Andes, Neuquén: Dirección Municipal de Cultura, 1998).

Foster, David William, Buenos Aires: Perspectives on the City and Cultural Production (Gainesville: The University Press of Florida, 1998).

Galen, Joseph, "Civilizing the Nation: Argentine Narratives of Education, Race, and Democracy," (Dissertation: University of California at Santa Cruz, 1999).

Green, Michael D. The Politics of Indian Removal: Creek Government and Society in Crisis (Lincoln: University of Nebraska Press, 1982).

Greenleaf, Richard E., ed., The Roman Catholic Church in Colonial Latin America (Tempe: Center for Latin American Studies, Arizona State University, 1977).

Güenaga, Rosario, "La Conformación Social de un Territorio de Inmigración," Revista de Indias (vol. 56, no. 206, 1996). 
Guía de Aves Silvestres de las Facultades de Agronomía y Ciencias Veterin arias by Norberto Montaldo and Juan Claver. University of Buenos Aires, College of Agronomy, 1986. www.agro.uba.ar/agrohtm/aves/lista.htm

Hanke, Lewis. Aristotle and the American Indians: A Study in Race Prejudice in the Modern World (Chicago: Henry Regnery Company, 1959).

Hughes, W., "Origin of the Tehuelche," Segment 57, in Folk Literature of the Tehuelche Indians (Los Angeles: UCLA Latin American Center Publications, 1984).

Instituto Nacional de Estadistica y Censos, Ministerio de Economía, www.indec.mecon.ar/default.htm

Jones, Miguel D., Letter from England written to Julio Roca, 19 April, 1881. Archivo General de la Nación, Carpeta 1383, Fondo Julio A. Roca.

Lamas, Andrés L., Pamphlet: Tierras Publicas y Colonización (Buenos Aires, Gráfico de Gunche, Wiebeck, y Turtl, 1899), General National Archive, Fondo Roca, Document 1383: Informes de Relaciones y Memorandums, 1833-1899."

Letter to the Editor. Carta al Director, La República, 25, 26, 27 June, 1876, Buenos Aires, Argentina. Archivo Nacional de la Nación, Fondo Roca, Folder 1391.

Letter to the Editor. Carta al Director, La Voz de Rio Cuarto, 28 June, 1876. Archivo General de la Nación, Fondo Roca, Folder 1391.

Letter from Dr. Jorge Gernadas to the governor of Buenos Aires, August 29, 1824. General National Archive, Buenos Aires, Argentina, Folder X13.4.4 (1824) "Plan de Colonización."

Letter to Don Estanislao Lopez, Buenos Ayres [sic], Nov., 5, 1835 and April 4, 1836, Library and Historical Archive of the Province of La Rioja, Papeles de Rosas, 18211850, Edición Oficial, Autorizada por...Provincia de Santa Fe, 1928.

Letter to Señor Comandante Politico y Militar, signed by fifteen hacendados including Matheo Lupin, Agustin Marguiando, Antonio Gonzalez, José Rial, Lucas Poza, Benito Crespo, Pedro Crespo, Alan Alvarez, etc. 1824. General National Archive, Buenos Aires, Argentina, Folder X13.4.4 (1824) "Plan de Colonización."

Lugones, Leopoldo, El Payador (Buenos Aires: Centurión, 1944).

Luna, Felix, Julio A. Roca-Series: Grandes Protagonistas de la Historia Argentina (Buenos Aires, Editorial Planeta Argentina, S.A.I.C, 1999). 
Mafud, Julio, "La Mujer Indigena," in La Psicología de la Viveza Criolla.(Buenos Aires: Distal, 1984).

Maldonado, Horacio, "Los Derechos Constitucionales de los Indígenas en Argentina y la Explotación de la Biodiversidad," speech from the International Workshop on Technical, Cultural, Political, and Legal Aspects of Bioprospecting in Argentina, 1996.

Manual del Alumno Bonaerense: $6^{\circ}$ Grado (Buenos Aires, Editorial Kapelusz, 1979)

Margulis, Mario. "La Discriminación en la Discursividad Social" in Mario Margulis, Marcelo Urresti, et. al., eds., La Segregación Negada: Cultura y Discriminación Social (Buenos Aires: Editorial Biblos, 1998).

Martínez-Echazábal, Lourdes, "Mestizaje and the Discourse of National/Cultural Identity in Latin America, 1845-1959," Latin American Perspectives (Vol. 25, No. 3, 1998, pp. 21-42).

Meade, Teresa, Civilizing Rio (University Park: The Pennsylvania State University Press, 1997).

Memoria del Departamento de Guerra y Marina, 1879, p. 6, in Juan Carlos Walther, La Conquista del Desierto: Lucha de Fronteras con el Indio (Buenos Aires: EUDEBA, 1970).

"Mensaje del presidente Avellaneda al Congreso," in Felix Luna, Julio A. RocaSeries: Grandes Protagonistas de la Historia Argentina (Buenos Aires, Editorial Planeta Argentina, S.A.I.C, 1999).

Moldes, Beatriz, and Antonia Peronja, "Historia de Río Negro, Capítulo II," "Historia de Río Negro, Capítulo I," Publication by the Ministry of Social Issues, Provincial Council of Education, Center for Scientific Investigations of the Government of Río Negro, 1998,

Nash, Gary, "The Hidden History of Mestizo America," The Journal of American History (December, 1995, \# 3).

Padden, Robert Charles, "Cultural Adaptation and Militant Autonomy Among the Araucanians of Chile," in John Kicza, ed., The Indian in Latin American History: Resistance, Resilience, and Acculturation (Wilmington, Del.: Scholarly Resources, Inc., 1993). 
Peña, Gabriela Alejandra, La Evangelización de Indios, Negros, y Gente de Castas en Córdoba del Tucumán durante la Dominación Española (1573-1810) (Córdoba, Facultade de Filosofía y Humanidades, Universidad Católica de Córdoba, 1997).

Proposal by Empresa de Colonización y Esplotación Rural e Industrial de los Territorios del Sud (Buenos Aires, 1899). Archivo General de la Nación, Carpeta 1383, Fondo Julio A. Roca.

"Proyecto Para Colonizar La Rioja," memorandum written by Felipe Cassini, Archivo General de la Nación, Documento 78-79, Carpeta 1383, Fondo Julio A. Roca. Not dated.

Puschmann, Heinrich, Universidad Católica de la Santisima Concepción, Chile, Department of Engineering, "The Nhewenh Mapuche Language Spelling" www.ict.uchile.cl/ hpuschma/mapuche

Ramos, Víctor, Racismo y Discriminación en Argentina (Buenos Aires: Editorial Catálogos, 1999).

Roca, Julio Argentino, Buenos Aires, August 14, 1878, Speech to the National Congress, in Juan Carlos Walther, La Conquista del Desierto: Lucha de Fronteras con el Indio (Buenos Aires: EUDEBA, 1970), Annex Number 13, Mensaje y Proyecto del Señor Ministro de Guerra y Marina, General don Julio A. Roca, Sobre la Traslación de la Frontera Sur a los Ríos Negro y Neuquén.

Rock, David, Argentina, 1516-1982: From Spanish Colonization to the Falklands War (Berkeley: Univesity of California Press, 1985).

Rodríguez, Adalberto, "Historia de Río Negro, Capitulo IV," Publication by the Ministry of Social Issues, Provincial Council of Education, Center for Scientific Investigations of the Government of Rio Negro, 1998.

Rosenberg, Mark B., A. Douglas Kincaid, and Kathleen Logan, eds., Americas: An Anthology (New York: Oxford University Press, 1992).

Saeger, James, "Eighteenth Century Guaycuruan Missions in Paraguay" in Susan E. Ramirez, et. al., Indian-Religious Relations in Colonial Spanish America (Syracuse: Maxwell School of Citizenship and Public Affairs, 1989).

Sarasola, Carlos Martínez, Nuestros Paisanos Los Indios: Vida, Historia y Destino de las Comunidades Indígenas en la Argentina (Buenos Aires: Emecé Editores, 1992). 
Sarmiento, Domingo Faustino, Facundo or Civilización I Barbarie: Vida de Juan Facundo Quiroga I Aspecto Físico, Costumbres, I Abitos de la Republica Arjentina [sic] (Santiago, Chile: Imprenta del Progreso, 1845), 1999 edition by Emecé Editores, S.A., Buenos Aires.

Sarramone, Alberto, Catriel y Los Indios Pampas de Buenos Aires (Azul, Bs. As.: Editorial Biblos, 1993).

Scutellá, Francisco N., El Mate: Bebida Nacional Argentina (Buenos Aires: Plus Ultra, 1989).

Servicio Nacional de Asuntos Indígenas del Ministerio de Salud y Acción Social, and Asociación Indígena de la República Argentina, Buenos Aires, 1977. Cited in Hernández, Isabel, Los Indios de Argentina (Madrid, MAFRE, 1992).

Siffredi, Alejandra, and Marcelo Bórmida, "The Emergence of the Earth,", Segment 22, in Folk Literature of the Tehuelche Indians (Los Angeles: UCLA Latin American Center Publications, 1984).

Siffredi, Alejandra, and Marcelo Bórmida, "The Origin of Man," Segment 60, in Folk Literature of the Tehuelche Indians (Los Angeles: UCLA Latin American Center Publications, 1984).

Siffredi, Alejandra, and Marcelo Bórmida, "The Rising of the Earth and the Origin of Mankind," Segment 62, in Folk Literature of the Tehuelche Indians (Los Angeles:

UCLA Latin American Center Publications, 1984).

Smith, Carol A., "The Symbolics of Blood: Mestizaje in the Americas," Identities, v. 3 (1997).

Svampa, Maristella, "Inmigración y Nacionalidad: El Caso de Argentina, 1880-1910," Studi Emigrazione/Etudes Migrations (Rome, 1993: Vol. XXX, NO. 110).

"Terminación del Gobierno del General Roca," La Tribuna Nacional (Buenos Aires, Argentina, 1887). Archivo General de la Nación, Fondo Roca, Folder 1391.

"The New Face of America" Time Magazine Special Issue (Fall, 1993).

Usner, Daniel, Indians, Settlers, \& Slaves in a Frontier Exchange Economy: The Lower Mississippi Valley Before 1783 (Chapell Hill: The University of North Carolina Press, 1992).

Vasconcelos, José, The Cosmic Race, trans. by Didier Jaén (Baltimore: The Johns Hopkins University Press, 1997). 
Vasquez de Espinosa, Antonio, "Compendium and Description of the West Indies," in Benjamin Keen, ed., Readings in Latin American Civilization: 1492 to the Present (Washington, DC: The Smithsonian Institution, 1942).

General Vintter, Note to the chief of state of the Military, 20 February, 1885. Memoria del Departamento de Guerra y Marina, in Carlos Martínez Sarasola, Nuestros Paisanos Los Indios: Vida, Historia y Destino de las Comunidades Indigenas en la Argentina (Buenos Aires: Emecé Editores, 1992).

Walther, Juan Carlos, La Conquista del Desierto: Lucha de Fronteras con el Indio (Buenos Aires: EUDEBA, 1970).

Whitten, Norman E., Jr. "The Ecuadorian Levantamiento Indigena of 1990 and the Epitomizing Symbol of 1992: Reflections on Nationalism, Ethnic-Bloc Formation, and Racialist Ideologies," in Jonathan D. Hill, ed., History, Power, and Identity:

Ethnogenesis in the Americas, 1492-1992 (Iowa City: University of Iowa Press, 1996).

Wilbert, Johanees, "Introduction," in Jonannes Wilbert and Karin Simoneau, eds., Folk Literature of the Tehuelche Indians (Los Angeles: UCLA Latin American Center Publications, 1984).

Wilkins, David E., American Indian Sovereignty and the U.S. Supreme Court: The Masking of Justice (Austin: University of Texas Press, 1997).

Williams, Jr., Robert A., The American Indian in Western Legal Thought: The Discourses of Conquest (New York: Oxford University Press, 1990).

White, Richard, The Roots of Dependency: Subsistence, Environment, and Social Change Among the Choctaws, Pawnees, and Navajos (Lincoln, Neb.: University of Nebraska Press, 1983).

Williams, Jr., Robert A., The American Indian in Western Legal Thought: The Discourses of Conquest (New York: Oxford University Press, 1990). 